\title{
ESTACIONALIDADE E CONCENTRACATO NO MERCADO ATACADISTA DE FRUTAS DO ESTADO DE SATO PAULO
}

\author{
MAURA SEIKO TSUTSUI ESPERANCINI MOREIRA \\ Engenteiro Agronômo
}

Orientador: Prof. Dr. EUARISTO MARZABAL NEVES

\begin{abstract}
Dissertacão apresentada à Escola Superior de Agricultura "Luiz de Queiroz", da Universidade de São Paulo, para obtencão do titulo de Mestre em Agronomia, Area de Concentração: Economia Agrária.
\end{abstract}

\author{
PIRAC I CABA \\ Estado de São Paulo - Brasil \\ Maio - 1991
}


Ficha catalográfica preparada pela Seção de Livros da Divisão de Biblioteca e Documentação - PCAP/USP

Moreira, Maura Seiko Tsutsui

M838e Estacionalidade e concentração no mercado atacadis ta de frutas do Estado de São Paulo, Piracicaba, 1991 .

150p, ilus,

Diss, (Mestre) - ESALQ

Bibliografia,

1. Fruta - Aspecto econômico - São Paulo(Estado)

2. Fruta - Comercialização - São Paulo(Estado) 3, Fru-: ta - Mercado - Estabilização 4, Fruta - Mercado -

Concentração 5, Fruta - Preço - Variação 6. Mercado atacadista - São Paulo(Estado) 7, Preço agrícola São Paulo(Estado) I, Escola Superior de Agricultura Luiz de Queiroz, Piracicaba,

$\mathrm{CDD} \quad 338,134$ 


\section{ESTACIONALIDADE E CONCENTRACRO NO WERCADO ATACIDISTA DE FRUTAS DO ESTADO DE SEO PAULO}

MAURA SEIKO TSUTSUI ESPERANCINI MOREIRA

Aprovada en: 08.05 .1981

Comissấo Jullgadora:

Prof. Dr. Evaristo Marzabal Neves

ESALQ/USP

Prof. Dr. Carlos José Caetano Bacha

ESALQ/USP

Prof. Dr. Toshio Nojimoto

FCA/UNESP

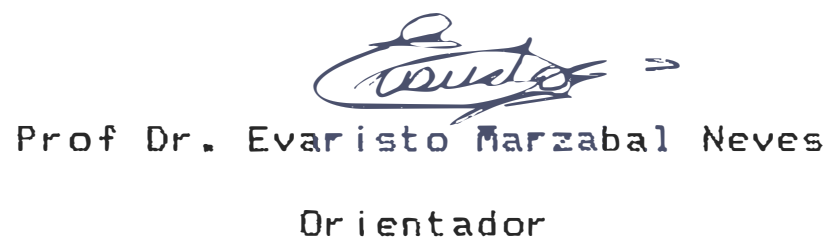


dos meus pais

Ofereco

do meu marido e filho

Dedico. 


\section{AGRADECIMENTOS}

Ao Prof. Evaristo Marzabal Neves, pela orientạุão e amizade.

A Escola Superior de Agricultura "Luiz de Queiroz" e ao Departamento de Economia e Sociologia Rural, pela oportunidade.

A CAPES, pela bolsa de estudas concedida.

Aos professores Carlos losé C. Bacha $\ominus$ Pedro Valentim Marques, pelas sugestões apresentadas.

Ao Prof. Toshio Nojimoto, pela leitura e sugestões apresentadas.

Aos professores do Departamento de Economia e Sociologia Rural da Faculdade de Ciências Agronômicas do Campus de Botucatu, pelo incentivo e amizade.

A todos que direta $e$ indiretamente contribuiram para a realizacão deste trabalho. 
SUMARTO

Página

LISTA DE TABELAS .................... v

LISTA DE ABREVIATURAS ................. $x$

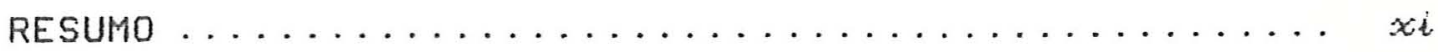

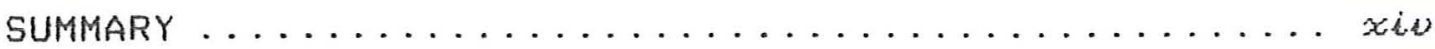

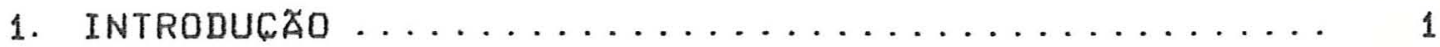

1. 1. Consideracões gerais ................. 1

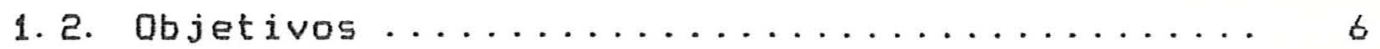

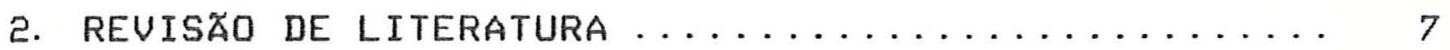

3. MATERIAL E MÉTODOS ......................... 20

3. 1. Material .................... 20

3. 2. Métodos .....................

3. 2. 1. Métodos para a estimativa do padrão de variacão estacional de precos ...... 22

3. 2. 2. Movimentos ciclicos ............ 28

3. 2. 3. Indicadores de concentracão ........ 29

3. 2. 4. Modelos de margens de comercializacão. 33

4. FAtORES QUE AFETAM a ESTIMATIUA DO PADRAO DE VARIACX̃O ESTACIONAL ................... 34

4. 1. Deflacionamento .............. 34

4. 2. Tendência .................... 5 E

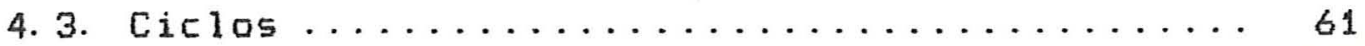

5. CONCENTRACÃO DA COMERCIALIZACÃO NO MERCADO ATACADISTA DE FRUTAS ................... 65

6. DETERMINACXO DO PADRAO DE UARIACÃO. ESTACIONAL DE PRECOS E QUANTIDADES .................... 78

7. CONCLUSõES ............................ 129

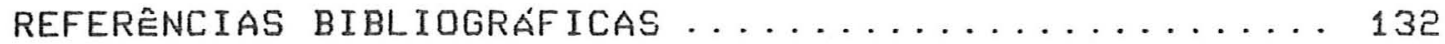

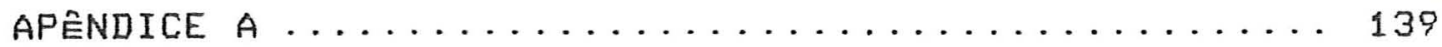




\section{LISTA DE TABELAS}

Página

Tabela 1.1. Porcentagem de perdas em relacão ao volume comercializado em diversos agentes de comercialização em 1984 na

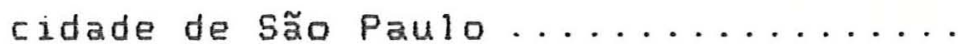

Tabela 4. 1. Indices sazonais de precos correntes $e$ deflacionados para 12 frutas comercializadas no atacado $e$ os testes $F$ obtidos. $1980-1988 \ldots \ldots \ldots \ldots 42$

Tabela 4. 2. Indices sazonais de precos correntes e deflacionados a nivel do produtor e os testes $F$ obtidos. $1980-1988 \ldots 46$

Tabela 4.3. Número de meses de entressafra e média das diferencas entre os indices estacionais calculados para precos reais e precos nominais do primeiro e último meses de safra .......... 50

Tabela 4. 4. Coeficientes de determinacão do ajustamento da média móvel de preços reais e nominais a funcões lineares $e$ exponenciais .................... 52

Tabela 4.5. Variaça absoluta dos indices estacionais de precos de algumas frutas no periodo de 1981 a $1987 \ldots \ldots \ldots \ldots$

Tabela 4. 6. Resultados da análise da tendência de precos das frutas estacionais ...... 56

Tabela 4.7. Resultados da análise estatistica para ciclos ...................... 63 
Tabela 5.1. Distribuicão da comercializacão de fru tas no mercado atacadista de São Paulo CEAGESP - Entreposto Terminal (1989). 68

Tabela 5. 2. Indicadores de concentracão da comercializacão no mercado atacadista de frutas no Estado de São Paulo, CEAGESP - Entreposto Terminal (1989) ........ 71

Tabela 5.3. Resultados das medidas de concentracão agrupadas por Cs e ordenadas pelo ind ce de Hirschmann ................ 72

Tabela 5. 4. Resultados das medidas de concentracão agrupadas por $\mathrm{C} 4 \mathrm{e}$ ordenadas pelo indi ce de Gini .................... 76

Tabela 6.1. Indices de variacão estacional de precas deflacionados $e$ quantidades de ameixa (cxt-7,30 kg) no mercado atacadista de São Paulo. Periodo 1980-1988. 81 Tabela 6.2. Indices de variacão estacional de precos deflacionados $e$ quantidades de caqui (cxt-4,50 kg) no mercado atacadista de São Paulo. Período 1980-1988. 84 Tabela 6.3. Indices de variacão estacional de precos deflacionados $e$ quantidades de figo (eng-1,80 kg) no mercado atacadista de São Paulo. Período 1980-1988. 87

Tabela 6.3.1. Indices de variacão estacional de precos deflacionados de figo (eng/3,5) recebidos pelos produtores do Estado de São Paulo. Periodo 1980-1988 ..... 88 
Tabela 6. 4. Indices de variacão estacional de precos deflacionados e quantidades de macã (ck-21, B0 kg) no mercado atacadista de São Paulo. Periodo 1980-1988. 91

Tabela 6. 4. 1. Indices de variacão estacional de precos deflacionados de magã (cx-40,00kg) recebidos pelos produtores do Estado de São Paulo. Periodo 1980-1988 ..... 92

Tabela 6.5. Indices de variacão estacional de precos deflacionados e quantidades de manga (ckm-25,00 kg) no mercado atacadista de São Paulo. Período 1980-1988. 95

Tabela 6.6. Indices de variacão estacional de precos deflacionados $e$ quantidades de mexerica (ckm-27,00 kg) no mercado atacadista de São Paulo. Periodo

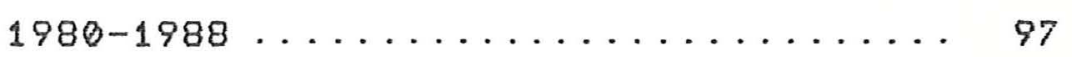

Tabela 6.7. Indices de variacõo estacional de precos deflacionados $e$ quantidades de morango (ces- $3,20 \mathrm{~kg}$ ) no mercado atacadista de São Paulo. Periodo

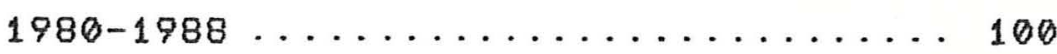

Tabela 6.7.1. Indices de variacão estacional de precos deflacionados de morango (cx $4,00 \mathrm{~kg})$ recebidos pelos produtores do Estado de São Paulo. Periodo 1980-

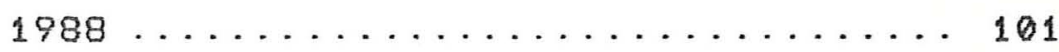

Tabela 6.8. Indices de variação estacional de precos deflacionados e quantidades de nectarina ( $c x k-2,25 \mathrm{~kg}$ ) no mercado atacadista de são Paulo. Periodo

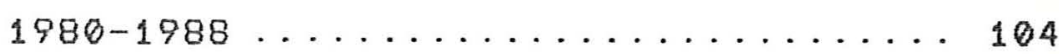


Tabela 6.9. Indices de variacão estacional de precos deflacionados e quantidades de néspera (cxt- $5,00 \mathrm{~kg}$ ) no mercado atacadista de São Paulo. Periodo

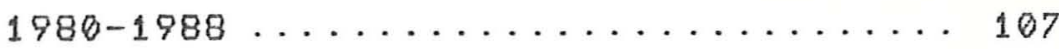

Tabela 6.10. Indices de variacão estacional de precos deflacionados e quantidades de pera (ck-17,00 kg) no mercado atacadista de São Paulo. Periodo

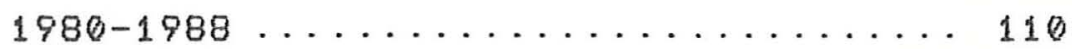

Tabela 6.11. Indices de variacão estacional de precos deflacionados e quantidades de péssego (cxt- $2,34 \mathrm{~kg}$ ) no mercado atacadista de São Paulo. Periodo

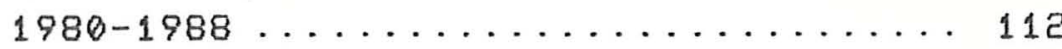

Tabela 6.11. 1. Indices de variacão estacional de prefos deflacionados de pêssego (cxt$2,5 \mathrm{~kg})$ recebidos pelos produtores do Estado de São Paulo. Periodo 1980-

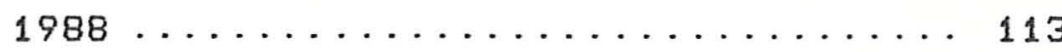

Tabela 6.12. indices de variacão estacional de precos deflacionados e quantidades de tangerina poncan (ckm- $27,00 \mathrm{~kg}$ ) no mercado atacadista de são Paulo. Periodo 1980-1988 .............. 116

Tabela 6.12.1. Indices de variação estacional de precos deflacionados de tangerina poncan (cxt-27,00 kg) recebidos pelos produtores do Estado de São Paulo. Periodo

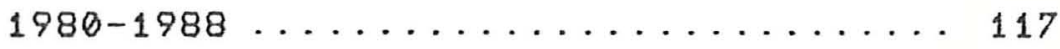


Tabela 6. 13. Indices de variacão estacional de precos deflacionados e quantidades de uva niágara (cxt-6,00 kg) no mercado atacadista de São Paulo. Periodo

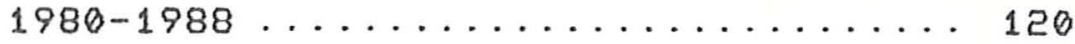

Tabela 6. 13.1. Indices de variaça estacional de precos deflacionados de uva niágara (cxt$8,0 \mathrm{~kg})$ recebidos pelos produtores do Estado de São Paulo. Periodo 1980-1988 121 


\section{LISTA DE ABREVIATURAS}

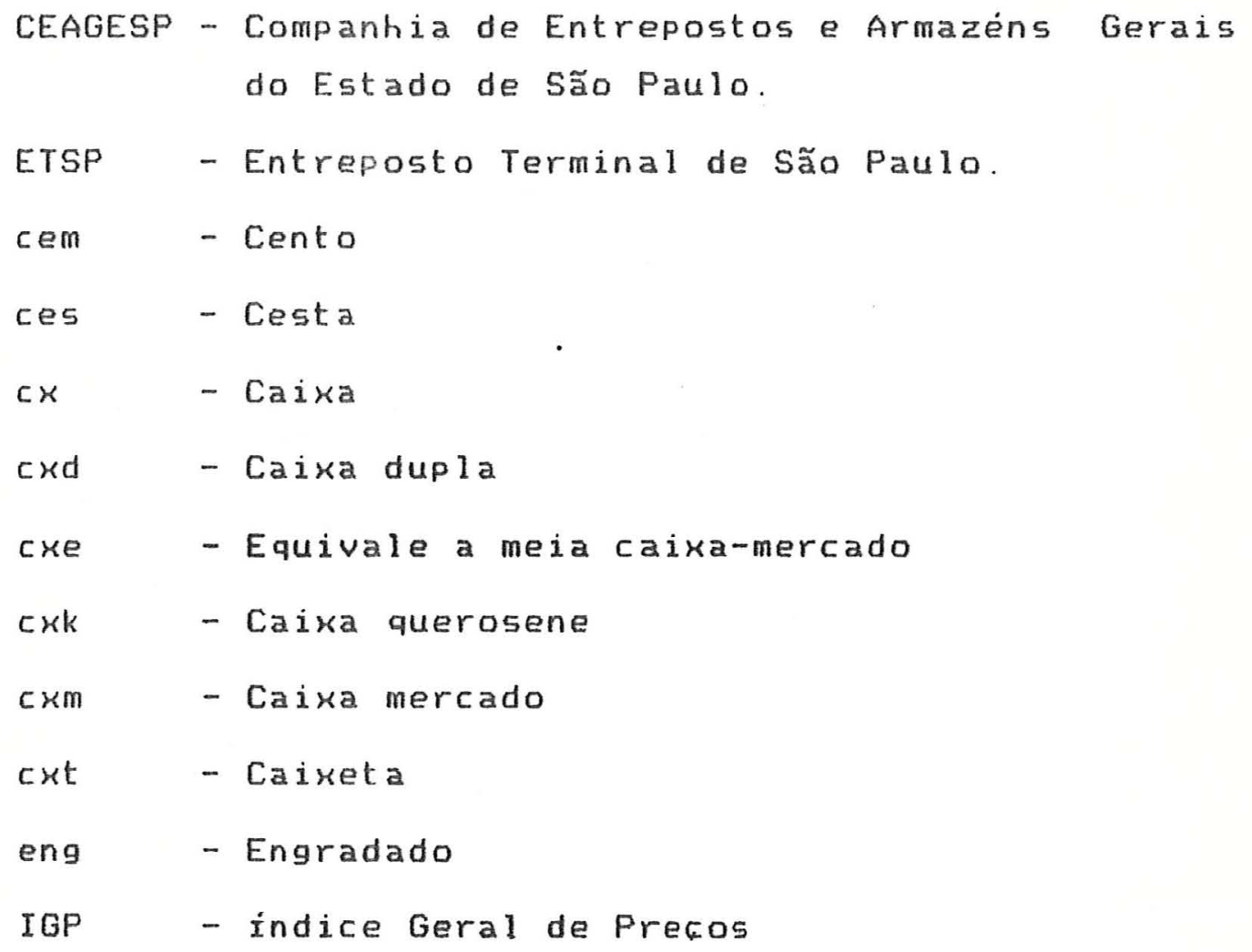




\section{ESTACIONALIDADE E CONCENTRACATO NO MERCADO ATACADISTA DE FRUTAS NO ESTADO DE SÃO PAULO}

Autor: MAURA SEIKO TSUTSUI ESPERANCINI MOREIRA

Orientador: PROF. DR. EVARISTO MARZABAL NEVES

RESUMO

Este trabalho tem por objetivo analisar aspectos da sazonalidade de precos de algumas frutas comercializadas no Estado de São Paulo.

Alguns fatores que afetam a estimativa dos indices estacionais, como as takas de inflacão e o componente ciclico também foram analisados. Foi utilizado o método da média móvel centralizada para estimar estes indices.

Procurou-se também avaliar o nivel de concentração no mercado atacadista e de que forma este afeta a sazonalidade nos precos. O grau de concentracão da comercialização foi determinado através de três indicadores de concentracão: Indice de Hirschmann-Herfindahl, parcela detida pelas quatro maiores (C4) e pelas oito maiores firmas (CB).

A influência da concentrąão da comercializacão nos indices estacionais foi analisada através da deter- 
minacão das politicas de margens adotadas pelos atacadistas $e$ o comportamento dos indices sazonais a nivel do atacado e do produtor.

Os resultados obtidos mostram que as taxas de inflacão podem afetar a estimativa dos indices estacionais quando estas são elevadas em relacão ao componente estacional, ao mesmo tempo em que se verificam periodos restritos de oferta, como ocorre com determinadas frutas estacionais. Nestes casos o deflacionamento se faz necessário, caso contrário, os indices estacionais podem estar super ou subestimados, principalmente nos meses iniciais $e$ finais de safra. Além disso, o deflacionamento não afetou o modelo escolhido.

Não foi detectada a presenca do componente ciclico de modo que este também não afetou o modelo escolhido.

Os resultados mostraram também que os principais fatores que afetam a sazonalidade dos precos das frutas analisadas são: temperatura, oferta de outras frutas, quantidade ofertada e aumento da demanda.

A influência da concentração da comercializacão nos indices estacionais verifica-se na medida em que permite aos intermediários imporem uma politica de margens rigidas. Isto faz com que as variacões de precos verificadas no atacado não sejam transmitidas de forma proporcio- 
nal aos produtores, alterando os indices de variacão estacional de precos ao produtor em relacão ao atacado.

Quando além da margem fixa, os intermediários impõem uma porcentagem sobre os precos pagos, os indices estacionais ao produtor e ao atacado são semelhantes. 
SEASONALITY AND CONCENTRATION IN FRUITS WHOSALE MARKET IN THE STATE OF SÃO PAULO

Author: MAURA SEIKO TSUTSUI ESPERANCINI MOREIRA Adviser: PROF. DR. EVARISTO MARZABAL NEVES

SUMMARY

This study intends to analyse price seasonality of some fruits commercialized in the state of São Paulo.

Some factors, which are expected to influence seasonal variation indices, such as cyclic component and inflationary rates, were also analysed. The centered moving average method was used in order to estimate these indices.

The concentration level of fruits wholesale marketing and the way it affects the price seasonality were also analysed. The concentration marketing degree was determined through three indicators: Hirschmann-HerfindahI Index, trade shared by the four greatest firms (C4) and trade shared by the eight greatest firms (C8).

The influence of concentration marketing in seasonal indices was analysed determining the margins policy adopted by the wholesalers and the behavior of the seasonal indices at wholesale and farm level. 
The obtained results showed that inflationary rates affect the seasonal indices when the first is as high as the seasonal component, and the analysed product presents restrict supply period, like some seasonal fruits. In these cases, the deflation is adviced, otherwise seasonal indices can be over or understimated, mainly for first and last months of supply period. Further, the deflation did not affect the chosen method.

Cyclical movements were not observed in data series, therefore they did not affect the chosen method.

The results also showed that main factors that affect the price seasonality of selected fruits are: temperature, other fruits supply, supplied quantity, and demand increase.

The concentration of fruits marketing can affect price seasonal indices as it provides conditions to wholesalers impose a rigid margin policy. This kind of policy makes price variation at wholesale level be transmit more than proportionally to farm level, changing the indices of price seasonality in the farm level relatively to wholesale level indices. If wholesalers impose a porcentual margin upon the farm prices in addition to a rigid margin, the indices observed at farm level and wholesale level are similar. 


\section{INTRODUÇÃO}

\subsection{Considerações gerais}

Dada a grande diversidade de climas no Brasil, é possivel o cultivo de uma gama variada de frutas tanto de clima temperado quanto de clima tropical.

Entretanto, mais recentemente 0 interesse pelo cultivo de frutas tem aumentado, principalmente em funcão da grande possibilidade de expansão das exportacões.

Segundo CARVALHO \& NABHAN (1984), a expansão das exportacões, em conjunto, caracteriza-se como menos dependente da importação de insumos do que a de produtos industrializados podendo o pais conseguir taxas maiores de crescimento de suas receitas liquidas de divisas com a exportacão de produtos agricolas que com as de produtos industrializados, pelo menos no curto prazo.

No ano de 1989, as exportacôes brasileiras de frutas frescas atingiram a marca de 235 mil toneladas, gerando uma receita de U\$ 54 milhões. A média de vendas no exterior entre 1985 e 1989 foi de 220 mil toneladas com receita média anual de U\$ 51 milhões. 
Alguns fatores podem vir a incrementar este quadro no curto prazo, como a produção de frutas de clima temperado. (No Estado de São Paulo, a producão de frutas frescas coincide com a entressafra dos paises do hemisfério norte abrindo possibilidade de expansão das exportač̃es para paises que são grandes consumidores de frutas frescas, como Alemanha, Japão, Reino Unido e Franca. Nestes periodos de entressafra o mercado dá preferência a frutos cujo paladar é mais familiar como macãs, peras e pêssegos.)

Segundo PENTEADO (1986) o incremento das exportacões deve superar alguns entraves no que diz respeito aos aspectos de produtividade, aparência dos frutos e condicôes fitossanitaries.

Já a fruticultura de elima tropical, apresenta vantagens quanto à possibilidade de ser explorada em várias regiões, diversificando as épocas de colheita e garantindo um abastecimento continuo, se o mercado assim o exigir.

As principais frutas exportadas pelo Brasil são tropicais: laranja, banana, melão, abacaki e manga; e os principais paises importadores são europeus, mas existem grandes perspectivas quanto aos mercados consumidores do Canadá e Japão.

Se os frutos apresentarem as caracteristicas exigidas pelo mercado externo quanto à qualidade, sabor e condicões de fitossanidade, em alguns casos, os precos 
podem ser superiores em até $50 \%$ em relacão ao mercado interno) (CODEVASF, 1989).

Dada a possibilidade do Brasil se firmar como exportador de frutas, cabe analisar aiguns aspectos destes cultivos principalmente no que diz respeito a precos e mercados onde estes se formam.

Assim como outros produtos agricolas, a producão de frutas caracteriza-se por forte instabilidade na produção, sobretudo por depender de condicões climáticas e biológicas.

As frutas estacionais, em particular, apresentam duas caracteristicas que reforcam o carater sazonal da oferta. Uma delas é o numero limitado de floracôes durante 0 ano. As frutas de cilma temperado (que componem a maioria das frutas estacionais) normalmente apresentam 1 floracão durante o ano, o que restringe a oferta a periodos bem delimitados.

Outro fator que reforca o caráter sazonal na oferta destas frutas é o alto grau de perecibilidade associados a estas frutas (ver Tabela 1.1), associado muitas vezes à inviabilidade técnica ou econômica de armazenagem. A implantacão de formas avancadas de armazenagem de frutas caminha a passos lentos, ainda que alguns resultados vêm sendo obtidos para máä e pera, por exemplo (Secretaria da Agricultura e Abastecimento/FAO, 1982). 
Tabela 1.1: Porcentagem de perdas em relaça ao volume comercializado, em diversos agentes de comercializaça em 1984 na cidade de São Paulo.

\begin{tabular}{lcccc}
\hline & \multicolumn{4}{c}{ Agente } \\
\cline { 2 - 5 } Fruta & Supermercado & Feira & Quitanda & Média \\
\hline Abacate & 27 & 22 & 15 & 22 \\
Abacaxi & 24 & 16 & 19 & 17 \\
Banana & 33 & 33 & 33 & 33 \\
Caqui & 40 & 21 & 22 & 23 \\
Figo & 30 & 10 & 20 & 13 \\
Laranja & 22 & 10 & 11 & 11 \\
Mamão & 34 & 28 & 32 & 29 \\
Manga & 24 & 18 & 29 & 19 \\
Melancia & 19 & 22 & 14 & 21 \\
Morango & 13 & 8 & 7 & 9 \\
Pêssego & 28 & 12 & 20 & 14 \\
Tangerina & 20 & 18 & 13 & 18 \\
Uva & 18 & 12 & 18 & 13 \\
\hline
\end{tabular}

FONTE: ALMEIDA (1985).

Outros elementos interferem na comercializa६ão e formacão de precos como: zonas limitadas para a producão (dadas as exigências climaticas destas culturas), mudancas na demanda e grau de eficiência na comercializaç̃o. 
Além disso, os precos agricolas se formam numa estrutura de mercado atacadista de relativa imperfeicăo, que ocorre pelo confronto de um grande número de produtores com alguns grandes intermediários, pela heterogeneidade do produto agricola, dificultando a classificacão, o armazenamento e a comercializacão, pela relativa imobilidade dos recursos produtivos e pela situacão de desinformacão que vive a maioria dos produtores em relação ao mercado de seus produtos.

As caracteristicas de sazonalidade e perecibilidade das frutas, associado à formacão de precos num mercado relativamente imperfeito que é o mercado atacadista, deve conferir as frutas grande instabilidade no mercado.

Este trabalho procura assim, analisar aspectos da variacão sazonal dos precos das frutas estacionais, assim como algumas caracteristicas da comercializacão de frutas, principalmente no que diz respeito ao grau de concentracão na comercializacão, procurando avaliar sua interferência na sazonalidade das precos.

Para isto este trabalho é dividido em 5 secôes. A primeira traz uma revisåo bibliografica gobre teoria e aplicacões; a segunda descreve o material e os métados empregados no estudo, a terceira faz uma andise dos fatores que interferem na estimativa dos indices 
sazonais, tais como inflação e ciclos. A quarta seça faz uma anailise das caracteristicas da comercializacão de frutas no mercado atacadista, principalmente no que diz respeito a concentracão da comercializacão. A quinta seç̃o traz uma analise do comportamento sazonal dos precos e procura analisar em que medida a concentracão no mercado atacadista interfere na sazonalidade de prefos.

1.2. Objetivas

o objetivo deste trabalho é estudar a estacionalidade de precos e quantidades de frutas no mercado atacadista (e ao produtor), bem como avaliar o grau de concentracão na comercializacão das mesmas.

Especificamente pretende-se:

- Verificar a influência de fatores como inflacão, tendência e ciclos na estimativa dos indices estacionais e determinar a sazonalidade de precos.

- Avaliar algumas caracteristicas da estrutura do mercado atacadista de frutas estacionais, principalmente no que diz respeito à concentraç̃o da comercializaçăo e em que medida isto interfere na sazonalidade de precos no at acado. 
2. REVISKO DE LITERATUEA

De modo geral pode-se classificar os movimentos das séries temporais ( $Y$ ) em quatro tipos: 1) Movimentos seculares ou de tendência $\left(T_{t}\right)$, e) Movimentos ciclicos $\left.\left(C_{\ell}\right), 3\right)$ Movimentos estacionais $\left(S_{\imath}\right)$ e 4) Movimentos aleatórios $\left(u_{t}\right)$, ou seja $Y=f\left(T_{t}, C_{t}, S_{l}, u_{t}\right)$.

o componente tendencial tem origem em fatores que exercen pouca influência a curto prazo, mas 5 ão bastante significativos ao longo de um periodo de vários anos. Em geral, o efeito destes fatores é monotônico, mas não elimina, entretanto, a possibilidade de uma reversão na tendência .

No lado da oferta o principal fator que pode provocar um movimento tendencial é o desenvolvimento tecnológico ou administrativo, que sendo incorporado às empresas agropecuárias, tem relacão positiva com a produção.

No lado da procura, as principais causas da tendência são o crescimento ou decréscimo demográfico elou de renda real e as modificacões nos gostos, preferências, padrão de vida da população e urbaniอ̨ąão. 
As séries de precos podem também apresentar movimentos ciclicos que são as oscilacões regulares não estacionais. Estas oscilacões podem ocorrer tanto do lado dos pregos quanto da producăo.

Segundo BRANDT (1979) os precos dos produtos agricolas tendem a ser afetados pelos ciclos econômicos. Problemas de instabilidade na procura existem nas regiões onde a elasticidade de renda da procura de produtos agricolas é relativamente alta e a economia näo agricola está sujeita a grandes variacões ciclicas. A medida que aumenta a renda dos consumidores e se estabiliea a economia não agricola, a demanda por produtos agricolas se torna mais estável que a procura por produtos năo agricolas.

Além da oscilação cíclica no lado da procura, pode existir o movimento ciclico que afeta a produç্心o, caracteristico de cada cultura, devido a fenômenos biológicos, como o caso do café, ou devido a variáveis econômicas como na pecuária de corte.

O componente irregular se dá quando forcas imprevisiveis (de ordem climatica ou biológica), tão comuns na atividade agropecuária, atuam nos preqos. Eventos esporádicos podem também afeta-los como ameaças de guerra, secas ou inundacões generalizadas.

A variacão estacional dos precos agricolas é bem caracterizada devido a estacionalidade da producão, 
embora não se deva desprezar variacões acentuadas no lado da demanda.

Para produtos não estocáveis, a estacionalidade é afetada pelos preços na entressafra que é funcão não só do custo de producão numa área mas também do custo de producão em outra área e do custo de transporte para o mercado em análise.

Segundo PEREIRA (1963), a intensidade dos indices de variaça estacional depende principalmente da viabilidade técnica e econômica do armazenamento. As variacões sazonais da maioria das frutas e verduras são relativamente maiores que outros produtos agricolas.

Variaços estacionais na procura podem variar muito em funcão de fatores climáticos (temperatura, umidade) ou institucionais, religiosos e culturais (festas juninas, Natal, Semana Santa, Finados), ou de renda (ex. recebimento de 132 salário).

Dentro de um determinado ano, em geral, as variacões climáticas tendem a afetar a quantidade produzida e os fatores culturais e sociais tendem a afetar a demanda pelo produto.

obviamente, a estabilidade do padrão de variacão estacional depende do comportamento dos fatores que causam esta flutuacão, em relacão a outros fatores.

Segundo MORETTIN \& TOLOI (1985), existem, de modo geral, dois enfoques utilizados na análise das séries 
temporais. Quando a análise é feita no dominio temporal, os modelos são paramétricos (ten un numero finito de parâmetross e neste caso inclul os modelos de regressăo e das médias móveis.

quando a análise é feita no dominio das frequências, os modelos são não paramétricos (têm um número infinito de parâmetros) e neste caso inclui-se os modelos de análise espectral. Este método consigte el decompor as séries temporais estacionárias em um conjunto de funçoses periódicas diferentes, onde cada ciclo se caracteriza por determinadas frequências e amplitudes. LEMOs et alii (1989), analisando ciclos de comércio agricola no Brasil, utilizou este método na análise de séries econômicas, destacando que é adequado para se identificar comportamentos das séries temporais em que os métodos tradicionais tornam-se deficientes.

Segundo MORETTIN \& TOLOI (OP. cit.), OE modelos de regressão são mais adequados para séries temporais que apresentam sazonalidade deterministica, ou seja, o componente estacional pode ser estimado a partir de dados dos meses anteriores.

Neste modelo, o componente sazonal pode ser dado por uma variável periódica (seno, cosseno ou variável "dummy"), o componente aleatório por uma variável de média 0 e variancia igual a $\sigma^{2}$ e. a partir da matriz de regressão é possivel obter os estimadores normais de 
minimos quadrados. Para séries que apresentam crescimento exponencial é aconselhável o uso de modelos multiplicativos e logaritmicos.

o método da média móvel é adequado para séries que apresentam tanto sazonalidade deterministica quanto estocástica. Este método consiste basicamente em determinar uma tendência de precos, dada pela média móvel e determinar os desvios em relacão a esta média.

A determinacão do padrão de variacão estacional pode ser feito através de dois modelos básicos. Um deles agrega os componentes da forma aditiva tal como $Y=A+T_{l}+C_{i}+S_{l}+u_{l}$. Neste modelo os componentas são desvios quantitativos. Esta pressupasicão de aditividade implica admitir que os componentes são independentes entre si, não importando, por exemplo, quão alto seja o nivel da tendência porque esta não afeta o componente estacional. Por exemplo, o fator que provoca aumento da producão é totalmente diferente do fator que provoca as variacões sazonais.

0 segundo modelo admite que os quatro componentes são relacionados entre si, e agregam-se de forma multiplicativa tal como $Y_{\ell}=A \cdot T_{\ell} \cdot C_{\ell} \cdot S_{\ell} \cdot u_{t}$. Os componentes são expressos como porcentagens na forma de indices. Uma vantagem deste modelo é que permite um conveniente isolamento dos componentes. 
Este é um método bastante utilizado devido a sua conceptão simples e relativa precisão dos resultados. Alguns autores descrevem algumas limitacões deste método, o que não invalida, entretanto, sua utilizacão.

YAMANE (1975) descreve alguns problemas que surgem quando se utiliza a média móvel para determinar a Iinha de tendência. Normalmente assume-se que a tendência representa um crescimento sistemático e os outros componentes, que são os componentes ciclicos, estacionais e irregulares, podem ser descritos como divergências da tendência.

Conforme demonstrado por LANGE (1967) 5e existem flutuacões periódicas de $n$ meses numa série, estas flutuacões são eliminadas com uma média móvel de $n$ meses. Entretanto, movimentos ciclicos e irregulares normalmente não tên estas flutuacões periódicas e o método da média móvel vai apenas parcialmente eliminar estes efeitas. Quando os trếs componentes $\left(C_{l}, S_{l} e u_{t}\right)$ estão combinados $e$ tratados como divergentes, provavelmente não existe periodo comum para os três elementos, de modo que a eliminaça das divergências gerá apenas parcial.

Um outro problema apontado pelo autor é que a média móvel quando aplicada a séries randômicas pode gerar uma série oscilatória. Tal fenômeno é conhecido como efeito slutzky-Yule. Uma série econômica geralmente contém um componente randômico. Assim, quando se toma a média móvel 
de uma série temporal para achar a tendêcia, também está se tomando a média móvel do componente randômico. 0 efeito Slutaky-Yule vai gerar uma série oscilatória que se torna parte da tendência ajustada.

0 autor recomenda cuidados ao utilizar a média móvel para projetar tendências. Deve-se admitir, por exemplo, que os fatores que provocam a tendência não sofrem modificações.

THDMSEN \& FODTE (1952) apontam que a média móvel tem a desvantagem de perder alguns dados no comego e no final da série. 0 outro problema apresentado pelos autores é que os movimentos marcantes de queda ou de alta tornam a média móvel totalmente não representativa da série naqueles pontos.

0 isolamento do componente cíclico não é considerado por diversos autores como MORETTIN \& TOLOI, 1985, SPIEGEL, 1970; HOEL, 1982, e YAMANE, 1975, que consideram que o ciclo e a tendência se devem a causas similares e não podem ser isoladas, formando o componente ciclico tendencial.

RIBEIRO (1977) utilizou a corregão de pręos pelo indice 2 da Fundacão Getúlio Vargas (IGP-DI) para eliminar as variacões ciclicas. Tal procedimento só é aceitável se se considerar que o componente ciclico da série de preços de um produto agropecuario apresenta a mesma evolucão ciclica do IGP, o que é bastante improvável. 
A variacão ciclica dos produtos agropecuarios obedece, na maioria das vezes, a um padrão biológico, situacão a que nem todos os componentes do IGP estão sujeitos, por isso, o autor supõe que o componente ciclico foi eliminado pelo deflacionamento dos precos, o que pode não ocorrer.

Para HOFFMANN (1980), a justificativa para a utilizacăo do método da média móvel é que todos os fatores que provocam variacões no nivel de precos entre anos, como mudancas na conjuntura e perdas de safras, podem ser incluidos num único componente.

SPIEGEL (1970) descreve mais alguns métodos para cálculo dos indices estacionais como:

1) Método da porcentagem média: os dados de cada mês são expressos em porcentagens da média anual. As porcentagens dos meses correspondentes dos diferentes anos são balanceadas mediante o emprego de uma media ou mediana. As doze porcentagens resultantes dão os indices por estacão. o problema deste método é que valores muito extremos podem viezar o resultado.

2) Método da tendência ou relação porcentual : neste método os dados de cada més băo expressos como porcentagens da tendência mensal. Uma média adequada das porcentagens dos meses correspondentes dá o indice desejado. A média subsequente dos valores $Y / T$ produz os indices por estacão e pode incluir variacões cíclicas ou irregulares, o que não deika de ser uma desvantagem deste método. 
3) Método dos elos relativos: os dados de cađa mês são expressos como porcentagem do mês anterior. São chamados de elos relativos porque encadeiam cada mes ao precedente. Toma-se uma média adequada dos elos referentes aos meses correspondentes. Desses 12 elos relativos podem ser obtidas as porcentagens relativas de cada mês, referida à de janeiro, que é de 100\%. O próximo més de janeiro pode apresentar um acréscimo ou decréscimo em relacão à tendência. Neste método, as várias porcentagens podem ser ajustadas para esta tendência. As porcentagens finais, corrigidas de modo a apresentarem a média de $100 \%$ proporcionam os indices por estacão desejados.

PEREIRA (1963) desenvolveu um método utilizado pelo Instituto de Economia Agricola (IEA). Este. é chamado de método do total móvel de 12 meses, onde cada preco mensal é expresso como porcentagem deste total. Estes precos foram totalizados para o 12 ano e centralizados sobre $07^{\circ}$ mês. A tendência e ciclo de preços aparecem no total móvel de 12 meses. Pela divisão de precos por este total elimina-se a tendência e os ciclos, permanecendo somente as variatooses estacionais e aleatórias. 0 método para calcular o indice de variacão estacional médio foi tomar cada preco mensal e dividi-lo pela média do periodo de 7 anos. Assim, o indice de variacão estacional médio mostra a relacão entre o preço em qualquer mês e o preco médio ajustado dos 7 anos. Este trabalho incluiu 9 produtos 
agropecuários no Estado de São Paulo e determinou também a relacão entre a amplitude do indice de variacão estacional médio e o grau de perecibilidade do produto.

- estudo da média móvel data de longo tempo. Na literatura americana, WAITE \& COX (1940) já utilizavam este procedimento para obter indices de variacão estacional de precos de produtos agricolas, no Estado de Minnesota, para o periodo de 1921 a 1935.

KOHLS (1985) destaca a importância destes estudos que mesmo com limitacões, ainda assim, estão entre as mais úteis ferramentas de auxilio à comercializacão disponiveis aos produtores. WAITE \& TRELOGAN (1948) enfatizaram a utilidade dos indices de variacão estacional como subsidio à escolha de alternativas, como armazenar o produto ou comercializá-10 imediatamente, relacionando a magnitude da variaga dos indices com os custos de armazenagem para produtos estocáveis.

Nos paises de clima temperado, a oferta estacional é bem mais caracterizada, principalmente para produtos não armazenáveis. JANECKE \& ALVENSLEBEN (1988) analisaram alguns aspectos da oferta sazonal e variacão de precos no mercado alemão de frutas e hortalias concluindo que a oferta de longo prazo e a flutuacão de precos nos mercados alemães são devidas a variafóes sazonais na producão, custos de armazenagem e demanda. No mercado de alfaces, por exemplo, se os preços no começo da estacão são 
altos a oferta aumenta consideravelmente, levando a baixos precos na média estacão e vice-versa. Para bens armazenáveis, como repolhos, batatas e macãs, se os precos do final da estação são altos, muito da colheita final é vendida e armazenada, mantendo os precos altos durante todo - periodo fora da estacão.

A comercializacão de produtos alimenticios é um dos elos fundamentais da articulacão da cidade com o campo. Com o rápido crescimento urbano verificado nas iltimas décadas, o sistema de comercializaça assume importância cada vez maior no abastecimento e sua eficiencia tem reflexos diretos na quantidade ofertada, na qualidade dos alimentos e no preco destes produtos (DICLER, 19897.

Diversos problemas têm sido analisados no sistema de comercializacão. WERNER \& BRAUN (1983) destacam - mercado atacadista como uma das principais causas das distorcões no sistema de comercializaç̃o e que a aç̃o oligopolistica dos grupos atacadistas reduz a influência de varejistas e produtores na formacão de precos.

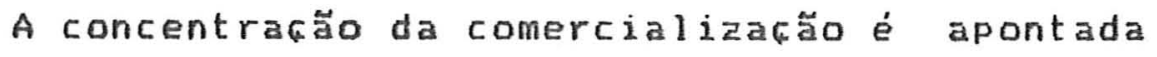
por alguns como um fator de distorcão do sistema de comercializaç̃o. PEROSA (1985) constata forte concentracão na comercialização de tomates no mercado atacadista, onde as quinze maiores fímas permissionárias foram responsáveis 
por $50,8 \%$ do total comercializado, num mercado onde atuam 432 atacadistas.

Dutra critica que se faz às Centrais de Abastecimento é que sua implantacão teve ônus de altos investimentos iniciais pelos Estados e as vantagens advindas de sua implantacão foram absorvidas quase que exclusivamente por atacadistas, cooperativas e firmas agroindustriais que aumentaram sua escala de producão, contribuindo para maior oligopolizacão do setor (DOMINGUES et alii, 1979).

ALMEIDA (1984) destaca o papel do mercado atacadista de São Paulo e sua condicão como o principal mercado formador de precos de hortifruticolas do pais. Os atacadistas de São Paulo afetam os preços em mercados longinquos ao comprar de distantes regiões produtoras e vender para diversos pontos do pais.

A atuacão dos atacadistas no mercado maringaense de hortifrutigranjeiros foi estudada por ASSUMPCXO et alii (1989). Neste trabalho os autores relacionaram algumas caracteristicas do mercado atacadista tais como concentracão da comercializacão, nivel de informacões no mercado atacadista e barreiras à entrada e saida de comerciantes, concluindo que é um mercado concentrado e especializado e exerce influência na determinacão de precos. D autor destaca, entretanto, que dada a grande 
proximidade de atacadistas entre si, a principal concorrência se dá via precos.

BARRQS (1989), analisando a transmissão de precos no mercado atacadista destaca seu papel preponderante na formacão destes, e que isto não ten necessariamente efeltos negativos ou positivos, mas sim se - atacado estabiliza ou ṇão o mercado.

BRANDT (1979) também destaca que o poder monopolistico do setor de intermediaça, por si, não é o problema, mas sim os reflexos sobre a instabilidade da produç̃o agricola. 
3. MATERTAL E METODOS

3.1. Haterial

As frutas selecionadas para o estudo de variaço estacional de precos e quantidades a nivel do atacado foram ameika, caqui, figo, macã nacional, manga, mexerica, morango, nectarina, pera, pêssego, tangerina poncan e uva niagara. As frutas selecionadas para o estudo de variação a nivel do produtor são apenas 6: figo, maçã, morango, pêssego, tangerina, uva niágara. Não existem informaçơs mensais sobre quantidade produzida.

0 estudo das caracteristicas da comercializaça de frutas no mercado atacadista incluiu outras frutas como abacate, abacaxi, banana, laranja, mamão, tangerina cravo, tangerina murcote e tangerina poncan, para comparaç̃o.

Os dados de precos e quantidades das frutas a nivel atacadista foram coletados junto a publicacones da Companhia de Entrepostos e Armazéns Gerais do Estado de São Paulo - Entreposto Terminal (CEAGESP-ETSP). Os precos são 
coletados diariamente no mercado atacadista e sua media refere-se ao numero de dias que o mercado trabalhou durante - mês.

Os precos ao produtor foram coletados em publicacões da Secretaria da Agricultura e Abastecimento-Instituto de Economia Agricola. Estes precos são baseados nas cotacooes das diversas regiones produtoras do Estado ponderadas pela estimativa de producão destas regiões.

Ds dados de quantidades vendidas por firma permissionaria são fornecidos pelos próprios atacadistas ao CEAGESP e são apresentados na forma de volume e porcentagem (em relaço ao setor) comercializada por cada permissionário, para cada fruta e por forma de comercializacão.

D deflator usado foi o indice Geral de Precos-Disponibilidade Interna (IGP-DI) coletado junto à Fundacão Getúlio Vargas, com base em dezembro de 1988 .

As frutas selecionadas para este estudo apresentam muita irregularidade no que diz respeito às estatisticas de precos e quantidades. Para contornar este problema alguns procedimentos foram tomados, como os que se seguem :

1. Os meses iniciais e finais da safra que não apresentaram dados regulares na maioria dos anos foram desprezados. Assim, o que se considerou periodo de oferta foram os 
meses em que os produtos têm cotacão regular. 0 ano para cada fruta, portanto, é formado apenas pelos meses da safra.

2. Nos casor em que apenas um determinado ano näo apresentou cotą̧ão em um mês considerado regular no periodo dé oferta, estimou-se um valor baseado na média dos anos anteriores, para não perder a série

- programa utilizado para o cálculo dos indices estacionais será o "IVE-15"1, desenvolvido para determinacão de indices estacionais para um número lexivel de meses.

3.2. Métados

3.2.1. Métodos para a estimativa do padrão de variação estacional de preços

o padrão de variacão estacional dos prę̧os foi determinado através do método da média móvel, descrito por HOFFMANN (1980), adaptado neste estudo para safras com número de meses inferior a 12.

1 Desenvolvido no Departamento de Economia e Sociologia Rural - Faculdade de Ciências Agronômicas - Campus de Botucatu - UNESP. 
Foram utilizados dois modelos teóricos: 0 da média aritmética e o da média geométrica.

3.2.1.1. Metodo da media aritmstica

Este modelo é apropriado para quando os precos apresentam tendência linear de crescimento $e$ a amplitude absoluta do componente estacional não varia ao longo do período analisado. Os precos $\left\langle P_{l}\right\rangle$ são o resultado da soma de 4 componentes básicos.

$$
P_{i}=P_{i j}=a+b \cdot t+e_{j}+u_{i}
$$

onde.

a) $a+b t e d a$ tendência linear, sendo a $e b$, parâmetros;

b) $e_{j}$ é o componente estacional, onde

$$
\Sigma e_{j}=0
$$

c) $u_{1}$ é o termo aleatório, com

$$
E\left(u_{b}\right)=0
$$

d) $i=1,2, \ldots m$ (numero de anos)

e) $j=1,2, \ldots, n$ (número de meses da safra, com $n \leq 12$ )

f) $t=1,2, \ldots, m \times n$ (número total de meses

$$
\text { q) } q=n-1
$$


Neste modelo as indices estacionais são estimados a partir da seguinte expressão.

$$
d_{i j}=d_{i}=P_{i j}-M_{i j}=P_{i}-M_{i}
$$

onde $P_{i j}$ é o preco relativo ao mês $j$ do ano $i$ e $M_{i j}$ é a média aritmética móvel centralizada correspondente

A média aritmética é dada pela seguinte expressão, quando o número de meses é par.

$$
\begin{aligned}
& M_{t}=a+b \cdot t+\sum e_{j} / n+\left(0,5 u_{t-(n / 2)}+u_{l-\{n / 2)+1}+\ldots+u_{l}+\right. \\
& \left.\cdots u_{1+\langle n / 2\rangle-1}+0,5 u_{1+(n / 2\rangle}\right\rangle / n\langle 3.5\rangle
\end{aligned}
$$

Nesta equacão o terceiro termo e a expressão entre parênteses são iquais e têm esperança igual a zero, dadas as pressuposicões (3.2) e (3.3), respectivamente.

Dessa forma as estimativas do indice estacional, obtidas pela expressão (3.4) são não tendenciosas, lembrando que:

$$
P_{i}-M_{i}=d_{i j}=e_{j}+u_{i}-\left(0,5 u_{i-(n / 2)}+\ldots+0,5 u_{l+6 n / 2)}\right) / n
$$

Cabe lembrar que a média aritmética móvel para um numero impar de meses difere da express ̃o (3.5), sendo definida por.

$$
\begin{aligned}
M_{l}=a+b t+\sum e_{1} / n+\left(u_{(-\langle q / 2)}+u_{t-(q-2)+1}\right. & +\ldots+u_{t}+\ldots+ \\
& \left.+u_{t+(q-2)-1}+u_{t+(q-2)}\right) / n
\end{aligned}
$$

Calculando-se a média dos $d_{i j}$ referentes a um mesmo mês obtêm-se estimativas mais eficientes. 


$$
\begin{aligned}
& \bar{d}_{j}=\left\langle\Sigma d_{i j}\right\rangle / k \\
& i=\left\{\begin{array}{rr}
1,2, \ldots, m \text { para } k=m \text { ou } k=m-1 \\
\text { ou } k, 3, \ldots \text { para } k=m-1
\end{array}\right.
\end{aligned}
$$

De acordo com (3.2) é necessário que o componente estacional apresente somatório igual a zero, devendo-se fazer a correcão (c):

$$
c=\left(\Sigma \bar{d}_{j}\right) / n
$$

A estimativa do componente estacional ( $\left.\hat{e}_{j}\right)$, que é um desvio quantitativo com a mesma unidade que a tendência, é dado por:

$$
\hat{e}_{j}=\bar{d}_{j}-c
$$

3.2.1.2. Metodo da média geomstrica

Este modelo é adequado para séries de precos que apresentam crescimento exponencial e a amplitude absoluta do componente estacional cresce com a nivel de precos. Neste modelo os precos são o resultado do produto de três componentes.

$$
P_{i j}=P_{t}=A \cdot B^{l} \cdot \varepsilon_{j} \cdot U_{t}
$$

onde.

a) $A B^{l}$ é a tendência, sendo $A$ e $B$ parâmetros $\operatorname{com} a=\ln A$ e $b=\ln B$. 
b) $\varepsilon_{j}$ é o componente estacional adimensional con.

$$
\begin{aligned}
& n \varepsilon_{j}=1 \\
& e_{j}=\ln \hat{\varepsilon}_{j} \\
& \sum e_{j}=0
\end{aligned}
$$

c) $U_{q}$ é o fator aleatório adimensional

$$
\begin{gathered}
E\left(\ln u_{l}\right)=0 \\
\ln u_{l}=u_{l}
\end{gathered}
$$

A nova expressão de precos transformada $\dot{e}$

dada por.

$$
\ln P_{L}=a+b t+e_{j}+u_{L}
$$

A partir da expressão (3.16) o processo é o mesmo do caso anterior, utilizando-se a média aritmética do logaritmo dos precos.

$g_{l}=a+b t+\sum e_{j} / n+\left(0,5 u_{t-(n / 2)}+\ldots+0,5 u_{t+1 n / 2\}}\right) / n(3.17)$ onde $g_{l}=\ln G_{t}$ e $G_{l}$ é a média geométrica dos precas $P_{l}$. o componente $e_{j}$ pode ser estimado a partir da seguinte expressão.

$$
d_{i j}=d_{L}=\ln P_{L}-g_{t}=\ln D_{i j} \text { onde } D_{i j}=\frac{P_{t}}{G_{L}}
$$

Os $d_{i j}$ obtidos 5ão estimativas não tendenciosas de $e_{j}$

$$
E\left(d_{i j}\right)=e_{j}=\ln E_{j}
$$


Da mesma forma que o caso anterior, é desejável que se utilize a média dos $d_{i j}$, para cada mês $j$ a fim de obter melhores estimativas.

$$
\bar{d}_{j}=\left(\Sigma d_{i j}\right) / k
$$

$i=\left\{\begin{array}{l}1,2, \ldots, m \text { para } k=m-1 \text { ou } k=m \\ 2,3, \ldots, m \text { para } k=m-1\end{array}\right.$

A correcão $(c) e$ as estimativas de $e_{j}$ são definidas por ( 3.8$)$ e (3.9), respectivamente.

Neste modelo, os indices estacionais são definidos por.

$$
I e=100 \cdot D_{L}=100 \exp \left[d_{l}\right]
$$

e os indices sazonais são dados por.

$$
\begin{aligned}
& \text { Is }=100 \hat{\varepsilon}_{j} \text { onde } \hat{\varepsilon}_{j}=\exp \left(\hat{\varepsilon}_{j}\right) \\
& 0 \text { desvio padrão dos } \hat{d}_{i j} \text { define o indice de }
\end{aligned}
$$

irregularidade.

$$
\begin{array}{r}
s_{j}=\exp \left\{\sqrt{\left(\sum d_{i j}-\bar{d}_{j}\right) / k-1}\right\} \\
i= \begin{cases}1,2, \ldots, m \text { para } k=m-1 \text { ou } k=m \\
2,3, \ldots, m \text { para } k=m-1\end{cases}
\end{array}
$$

Os dois modelos foram testados e escolhidos segundo critérios de ajustamento da tendência e amplitude do componente estacional. 


\subsubsection{Movimantos clclicos}

A existência de ciclos bienais nos preqos das frutas foi verificado através do modelo de regressäo, semelhante ao utilizado por SATO (1988)

Este modelo procura captar a diferenca de padrão de variacão estacional entre anos pares e anos impares e é dado por:

$$
P_{i j}=\alpha+\sum \beta_{h} z_{i h}+\sum \gamma_{f} x_{i f}+u_{i j}
$$

a) $P_{i j}=$ preco mensal deflacionado;

b) $\alpha$ = termo constante da regressão associada ao preco médio no mês n em ano par;

c) $z_{\text {ih }}=$ variavel binária que capta a variacão estacional para o ano par;

d) $x_{\text {if }}=$ é a variável binária que capta a diferenca de padrão de variacão estacional de anos pares para anos impares;

e) $i=1,2, \ldots, m$ (numero de anos)

f) $j=1,2, \ldots, n$ (número de meses)

g) $h=1,2, \ldots, n-1$ (numero de meses do ano par)

h) $f=1,2, \ldots, n$ (número de meses do ano impar)

Assim tem-se para os anos pares $x_{i f}=0$ para todo f. Para o mês $n$ (último mês da safra) tem-se $E\left(P_{i j} / Z_{i h}=0\right.$ paratodo $\left.h\right)=\alpha, e E\left(P_{i j} Z_{i h}=1\right.$ para $h=j e$ $z_{i h}=0$ para $\left.h \neq j\right)=a+\beta_{h}$ para os demais meses. 
Para os anos impares tem-se $x_{\text {if }}=0$ para $f \neq j e X_{i f}=1$ para $f=j$ ). Para o mês n tem-se $E\left(P_{i j} / Z_{i h}=0\right.$ para todo $\left.h\right)=\alpha+\gamma_{n}$ epara os demais meses tem-se.

$E\left(P_{i j} / Z_{i h}=1\right.$ para $j=h$ e $Z_{i h}=0$ para $\left.h \neq j\right)=a+\beta h+\gamma_{i}$ A hipótese testada será a seguinte.

$$
H_{0} \cdot \gamma_{1}=\gamma_{2}=\ldots \cdot \gamma_{n}=0
$$

Se o teste F for significativo rejeita-se a hipotese de nulidade aceitando-se que existe diferenca no padrão de variação estacional entre anos pares e impares.

Para o teste F utilizou-se o nivel de significância de $5 \%$ por ser o mais usual.

\subsubsection{Indicadores de concentração}

Para quantificar o grau de concentracão da distribuicão do volume comercializado no mercado atacadista de São Paulo - Entreposto Terminal, foram utilizadas três medidas de concentraça:o: o indice de Hirschmann-Herfindahl (HDFFMANN et alii, 1976), a parcela detida pelas 4 maiores firmas (CA) e a parcela detida pelas 8 maiores firmas (Ca) (CARUALHO et alii, 1970), e uma medida de desigualdade. indice de Gini (HOFFMANN, 1980). 
3.2.3.1. Indice de Hirschmann-Herfindahl $C$ D

Este indice mede o grau de concentracão de uma distribuicăo sem levar em consideracăo sua ordem e é definido por.

$$
H=\sum P_{i}^{2} \quad i=1, \ldots, n
$$

onde:

a) $P$ é a participacão decimal ineste caso o volume comercializado) de cada individuo (permissionario),

b) $i=1, \ldots, n$ (numero de individuos)

0 indice $H$ tende para zero quando $n$ tende para o infinito e todos os individuos têm a mesma participacão $\left(P_{1}=P_{2}=P_{3}=\ldots=P_{n}\right)$. 0 mercado será tanto mais concorrencial quanto menor for o valor de $H$.

0 indice $H$ tende a 1 quando um único individuo tende a elevar sua participação no mercado para 1 $(100 \%)$. Neste caso extremo tem-se um mercado de monopolio.

Este indice caracteriza-se por ser influenciado pelos pérmissionários com elevada participacăo no mercado. Por outro lado, a existência de um grande número de permissionários com reduzida participacão não altera significativamente este indice. 
3.2.3.2. Parcela detida pelas 4 maiores firmas (CA) e pelas 8 matores (C8)

Esta é uma medida bastante comum no setor industrial que relaciona a participacão dos agentes econômicos na producão total com a estrutura do mercado, desenvolvida por Bain", citado por CARUALHO et alii (1984).

o autor estabelece as seguintes categorias, segundo a porcentagem do mercado detida pelas 4 maiores firmas (Cs).

a) $0 \%$ a $25 \%$ - atomismo,

b) $25 \%$ a $50 \%$ - oligopólio levemente concentrado ou de baiko grau;

c) $50 \%$ a $75 \%$ - oligopólio concentrado;

d) mais de $75 \%$ - oligopólio altamente concentrado.

Neste estudo relacionou-se a participacão dos atacadistas da CEAGESP no volume total comercializado com a estrutura deste mercado.

Foi utilizado também o indice ca para captar possiveis distorqões do indice $\mathrm{C}$.

\footnotetext{
"BAIN, J.S. Industrial organization. 2ed. sl, John wiley \& Sons, 1968, 678p
} 
Este indice mede o grau de concentracão de uma distribuicăo. Neste estudo, será analisada a distribuicão do volume comercializado éntre os permissionários do mercado atacadista no Entreposto Terminal da CEAGESP.

D indice de Gini é obtido colocando-se na abscissa de um sistema cartesiano a porcentagem acumulada dos individuos, em ordem crescente de participacão, e na ordenada as fracões acumuladas de volume comercializado.

Se a cada porcentagem acumulada de individuos correspondesse igual porcentagem acumulada de volume comercializado, seria definida uma linha de perfeita igualdade correspondente à diagonal de um quadrado.

Como isto normalmente não ocorre, isto é, a cada porcentagem acumulada de individuos corresponde a uma porcentagem menor de volume comercializado, forma-se uma linha distante da linha de perfeita igualdade. 0 indice de Gini é estimado através da relação entre a área formada por estas duas linhas e a área do triângulo isósceles formada pela linha de perfeita igualdade.

Este indice apresenta a caracteristica de ser influenciado basicamente pelos individuos com reduzida participacăo e pelas grandes porcentagens detidas por poucos permissionarios. 
3.2.4. Modelo de margens de comercializaçăo

o modelo proposto para a análise de margens consiste no ajustamento da seguinte funcão utilizada por CARVALHO (1980).

$$
M_{c}=C_{0}+C_{1} \mathrm{Pd}
$$

onde $\mathrm{Me}=\mathrm{Pa}-\mathrm{Pd}$ é a margem absoluta expressa em unidade de preço; Fa é o preço praticado no atacado e Pdé o preco recebido pelo produtor. O coeficiente co é o intercepto da funcão e cl é o coeficiente de $\mathrm{Pd}$.

- teste dos parâmetros Co e Ca permite identificar o tipo de politica de margem adotado pelos atacadistas: os intermediários podem adotar margens relativas constantes $\left(C_{0}=\emptyset\right.$ e $C_{1}$ ) $\theta$ ), margens relativas crescentes $\left(C_{0}(O\right.$ e $\left.\mathrm{C} i{ }\rangle\right)$, margens relativas decrescentes (Co) $\theta$ e $A(\theta)$, margens absolutas constantes ( $C_{0}$ ) $\theta$ e $C_{1}=0$ ), margens absolutas crescentes (Co) $\theta \in[a$ ) 0 ), etc. 
4. FATORES RUE AFETAM A ESTIMATIVA DO PADREO DE VARIACTAO ESTACIONAL

\subsection{Derlacionamento}

Esta seção procura analisar a importância de fatores que afetam a estimativa dos indices sazonais quando se utiliza a média móvel. Este método foi escolhido por ser um dos mais utilizados para a obtencão dos indices de variacão estacional em funcão não só à sua simplicidade de concep̧ão, mas também à facilidade com que são feitos os cálculos nos programas desenvolvidos para tal.

A maioria dos autores que utiliza a média móvel para a estimativa dos indices estacionais não procede a um prévio deflacionamento de precos, pois os primeiros trabalhos desenvolvidos que utilizaram este método atestam que a média móvel capta o efeito inflacionário e o elimina quando se procede ao cálculo dos indices estacionais. Os trabalhos realizados na década de 60 como os de HOFFMANN (1969) realmente confirmam a indiferenca quanto à utilizacão de precos reais ou nominais. É importante destacar, entretanto, que as condicões em que estes 
trabalhos se desenvolveram, na década de 60 , permitiam utilizar os precos nominais, pois neste periodo os indices inflacionários eram pouco significativos em reląão aos indices estacionais.

Tal procedimento, entretanto, vem sendo utilizado por diversos autores, mesmo em periodos em que se verificam elevados indices de inflacão (NOGUEIRA et alii, 1984 e NOGUEIRA et alii, 1985). Nesta secão pretende-se mostrar que este procedimento é recomendado sob determinadas condições.

Considerando o modelo 3.1. tem-se:

$$
P_{i}=P_{i j}=a+b t+c_{l}+e_{j}+u_{i}
$$

onde.

$$
\begin{aligned}
& P_{l}=\text { preço do produto; } \\
& a=\text { preco iniciali } \\
& b_{t}=\text { tendência de crescimento do preço; } \\
& c_{l}=\text { aumento de preço devido à inflaçăo, } \\
& e_{j}=\text { variacões sazonais, } \\
& u_{l}=\text { variacões aleatórias. }
\end{aligned}
$$

A média aritmética (de 12 meses) será:

$$
M_{t}=\left(0,5 P_{t-6}+P_{t-5}+\ldots+P_{t+5}+0,5 P_{t+6}\right) / 12
$$

Substituindo (4.1) ea (4.2) e sabendo-se que $\sum_{j=1}^{12} e_{j}=0$, segue-se que: 


$$
\begin{aligned}
M_{t}= & a+b t+\left[\left(0,5 C_{t-6}+c_{t-5}+\ldots+c_{t+5}+0,5 c_{t+6}\right)+\right. \\
& \left.+\left(0,5 u_{t-6}+u_{t-5}+\ldots+u_{t+5}+0,5 u_{t+6}\right)\right] / 12 \quad(4,3)
\end{aligned}
$$

Subtraindo a média móvel $M_{t}$ do preco $P_{t}$ obtém-se $d_{\mathfrak{\imath}}$ :

$$
\begin{gathered}
d_{t}=d_{i j}=P_{t}-M_{t}=P_{i j}-M_{i j} \\
d_{t}=c_{t}+e_{j}+u_{t}-\left[\left(0,5 C_{t-6}+c_{t-5}+\ldots+C_{t+5}+0,5 C_{t+6}\right)+\right. \\
\left.\left(0,5 u_{t-6}+u_{t-5}+\ldots+u_{t+5}+0,5 u_{t+6}\right)\right] / 12 \quad \text { (4.5) }
\end{gathered}
$$

Como $E\left(u_{t}\right)=0$ para todo $l$, dada a pressuposiç̃o (3.3) tem-se:

$E\left(d_{t}\right)=e_{j}+C_{t}-\left[\left(0,5 C_{t-6}+c_{t-5}+\ldots+C_{t+5}+0,5 C_{t+6}\right)\right] / 12$

Considerando que a média móvel do componente inflacionário seja $\bar{C}_{\mathfrak{t}}$, isto é,

$\bar{c}_{t}=\frac{1}{12}\left(0,5 C_{t-6}+c_{t-5}+\ldots+c_{t+5}+0,5 C_{t+6}\right)$

Obtém-se a seguinte equą̧ão:

$$
E\left(d_{i j}\right)=\theta_{j}+\left(C_{t}-\bar{C}_{t}\right)
$$

A partir da eq. (4.8) admite-se que o componente estacional calculado será não tendencioso se o componente inflacionário no periodo $t$ for igual à média 
móvel centralizada em $l$ dos componentes inflacionários, ou seja, se $C_{l}-\bar{C}_{l}=0$. Caso contrário, a estimativa do componente estacional incorpora um residuo, que é a diferenca entre $c_{l}$ e $\bar{c}_{l}$.

Existem casos em que esta pressuposiço de não tendenciosidade é perfeitamente possivel, como nos casos onde componente inflacionário é igual em todos os meses do ano $\left(C_{l-1}=C_{\ell}=C_{l+1}\right.$, para todo 1$)$, ou ainda quando $C_{l} \dot{e}$ tão pequeno que pode ser incluido no termo aleatório.

No entanto, é mais comum verificar indices inflacionários elevados e com grandes irregularidades, em Especial no periodo analisado (1980-1988).

A irregularidade dos prefos causada pela elevacão ou queda brusca destes indices pode provocar movimentos bruscos na série tornando a média móvel não representativa da série conforme mostrou THOMSEN \& FOOTE (1952).

Este fenômeno apesar de indesejável pode ser diluido quando sua ocorrência é eventual, uma vez que se faz a média dos indices estacionais.

Entretanto, se estes movimentos são sistemáticos, os vieses introduzidos podem ser bastante acentuados refletindo-se fortemente na estimativa dos indices sazonais. 
Tal fenômeno ocorre para produtos com oferta temporária uma vez que o diferencial de pregos do final de uma safra para o inicio da outra é muito grande porque incorpora os indices inflacionários do periodo de entressafra.

Por exemplo, se o indice de inflacão fosse constante e igual a $5 \%$ ao mês, e houvesse um periodo de ausência de oferta de quatro meses, o diferencial de inflacão do final de uma safra para o inicio de outra seria de $21,55 \%$, ao passo que de um mês de oferta para outro seria de apenas $5 \%$

Esta descontinuidade de oferta tem o mesmo efeito de uma variacão brusca nos precos, devendo-se proceder a um prévio deflacionamento de precos.

A media móvel que deveria acompanhar o movimento geral da série para as frutas estacionais, se acha superestimada antes do movimento, pois capta os precos altamente inflacionados ocorridos no inicio da safra seguinte e após o movimento a média móvel se acha subestimada pois inclui os precos defasados ocorridos na safra anterior.

Este comportamento da média móvel provoca desvios sistematicos na estimativa dos indices sazonais calculados para os meses imediatamente anteriores e posteriores ao movimento. 0 uso de precos correntes nestes 
casos leva a subestimar os indices estacionais dos meses finais da safra e superestimar estes valores nos meses iniciais.

No Apêndice A săo apresentados diferentes comportamentos de precos devido à inflacão e seus efeitos sobre as estimativas dos indices estacionais.

Pode-se afirmar que estas condicões (periodo de ausência de oferta em presenca de altas taxas inflacionárias) tornam as estimativas dos componentes estacionais viesadas.

Se isto de rato ocorre, os indices estacionais devem apresentar as seguintes caracteristicas:

1) 0 valor central, se existir, deve apresentar diferenca minima entre os indices calculados para precos reais e precos nominais.

2) Os indices estacionais para precos nominais estarão superestimados no inicio da safra e subestimados nos finais da safra em relação aos indices calculados para precos reais e os desvios devem ser maiores para os meses iniciais e finais da safra.

3) Quanto maiores o periodo de entressafra e as takas inflacionárias, as diferencas entre os indices calculados para precos reais e precos nominais tendem a ser maiores. 
Nesta análise pressupõe-se que são os indices reais que realmente refletem o comportamento estacional dos precos ao longo do ano.

Como mencionado anteriormente, apenas pode-se esperar que o componente inflacionário seja eliminado pela média móvel, se estes se apresentarem muito regulares ao longo do período analisado ou forem muito reduzidos em relação ao componente aleatório.

05 indices inflacionários poderiam, ainda, servir apenas para reforcar as estimativas dos componentes estacionais, pois nos periodos de entressafra normalmente espera-se que os precos se elevem, afetando as expectativas inflacionárias e com isto os próprios precos, já que se trata de uma economia indexada. Entretanto os produtos selecionados para este estudo tem pouca importância em termos de produtos com os quais são calculados os indices de inflação. Por esta razão admite-se que os preços reais são mais adequados para estimar o padrão de variąão estacional, portanto, é desejável que a inflação seja eliminada das análises. De acordo com os resultados obtidos, verifica-se que alguns comportamentos previstos para os indices sazonais foram confirmados.

A primeira hipótese foi confirmada, pois os produtos que apresentavam um numero impar de meses, sempre apresentavam uma diferenca minima entre os indices 
calculados para preços reais e nominais para o mês central (Ver Tabelas 4.1 e 4.2).

A diferenca aumenta à medida que se àproxima dos valores extremos, confirmando também a segunda hipótese, isto é, que os valores extremos (do inicio e de final de safra), sempre apresentam maiores diferencas entre os indices calculados para valores reaí e valores nominais.

Os dados confirmam também que os indices sazonais estäo superestimados para os meses do inicio de safra e subestimados para os meses finais de safra, que foi verificado para todos os produtos. 
Tabela 4.1 - indices sazonais de precos correntes e deflacionados para 13 frutas comercializadas no atacado, e os testes $F$ obtidos. 1980-1988.

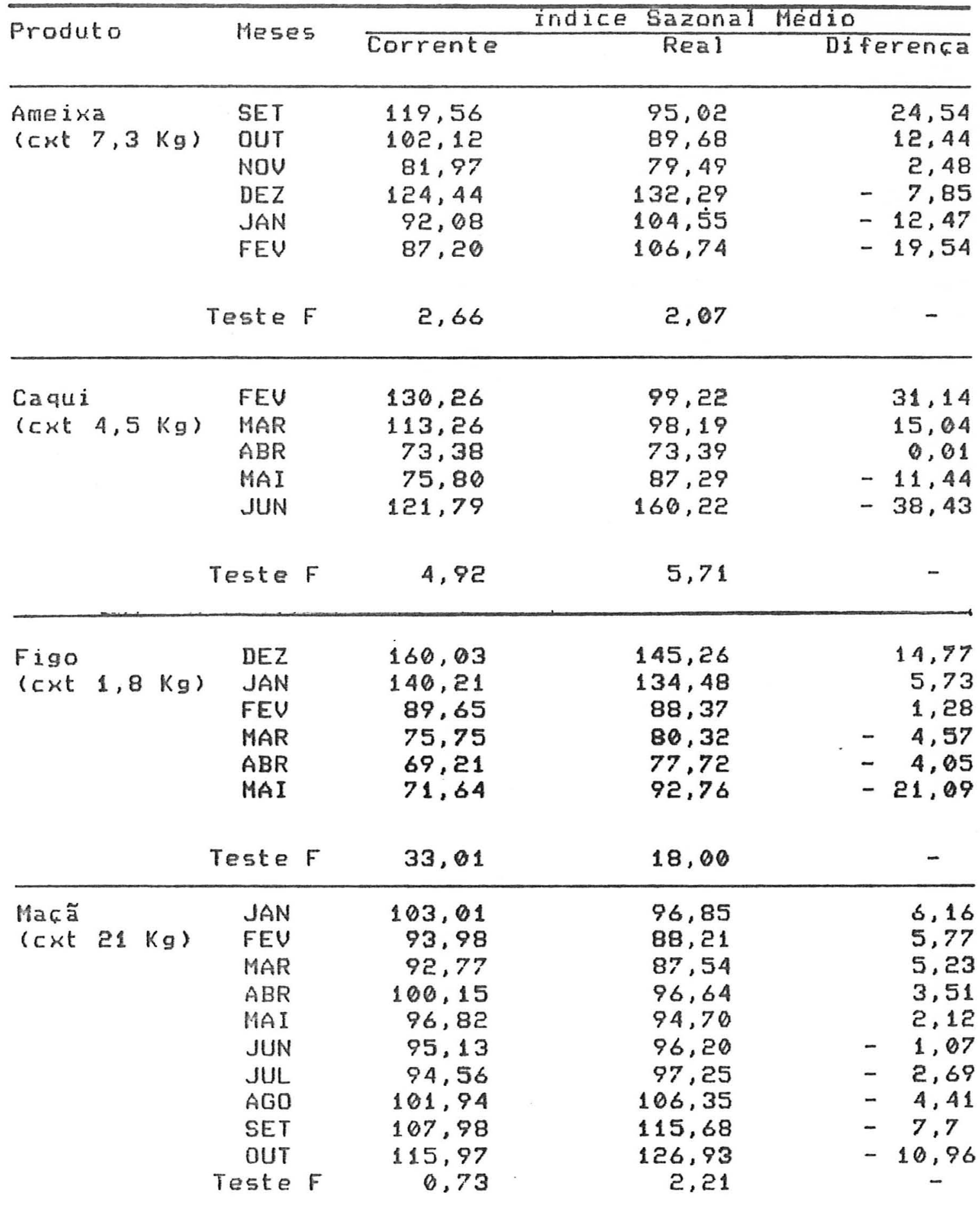


Tabela 4.1 - indices sazonais de precos correntes e deflacionados para 13 frutas comercializadas no atacado, e os testes $F$ obtidos. 1980-1988.

Produto Meses corrente indice Sazonal Médio

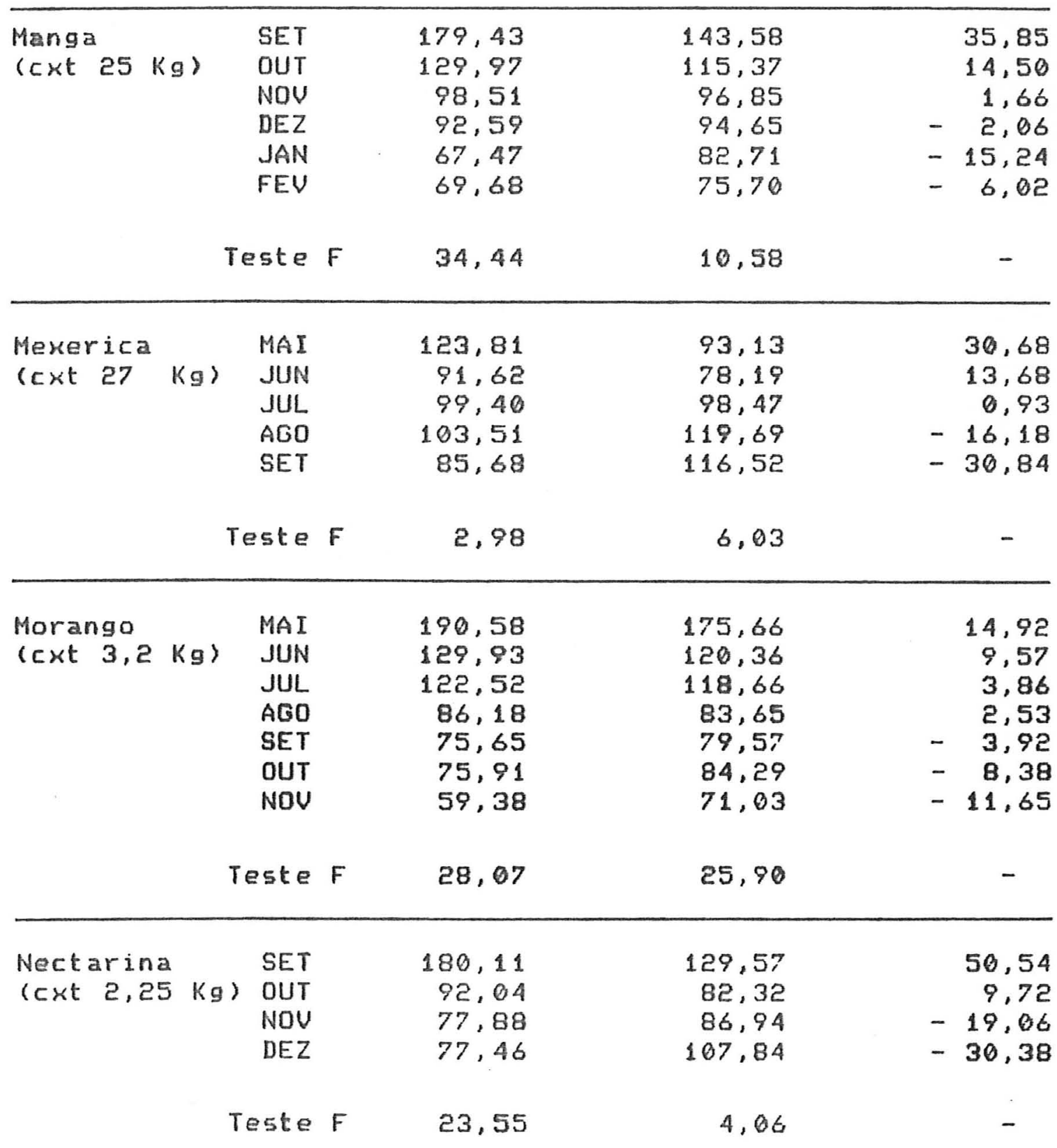


Tabela 4.1 - indices sazonais de precos correntes e deflacionados para 13 frutas comercializadas no atacado, e os testes $F$ obtidos. 1980-1988.

\begin{tabular}{|c|c|c|c|c|}
\hline \multirow{2}{*}{ Produto } & \multirow{2}{*}{ Meses } & \multicolumn{3}{|c|}{ Indice Sazonal Médio } \\
\hline & & Corrente & Real & Diferenca \\
\hline \multirow{5}{*}{$\begin{array}{l}\text { Nêspera } \\
(\text { cxt } 5,00 \mathrm{~kg})\end{array}$} & JUN & 147,28 & 108,21 & 39,07 \\
\hline & JUL & 148,66 & 126,90 & 21,76 \\
\hline & $A B O$ & 101,58 & 101,30 & 0,28 \\
\hline & SET & 73,26 & 85,70 & $-12,44$ \\
\hline & OUT & 61,38 & 83,95 & $-22,57$ \\
\hline
\end{tabular}

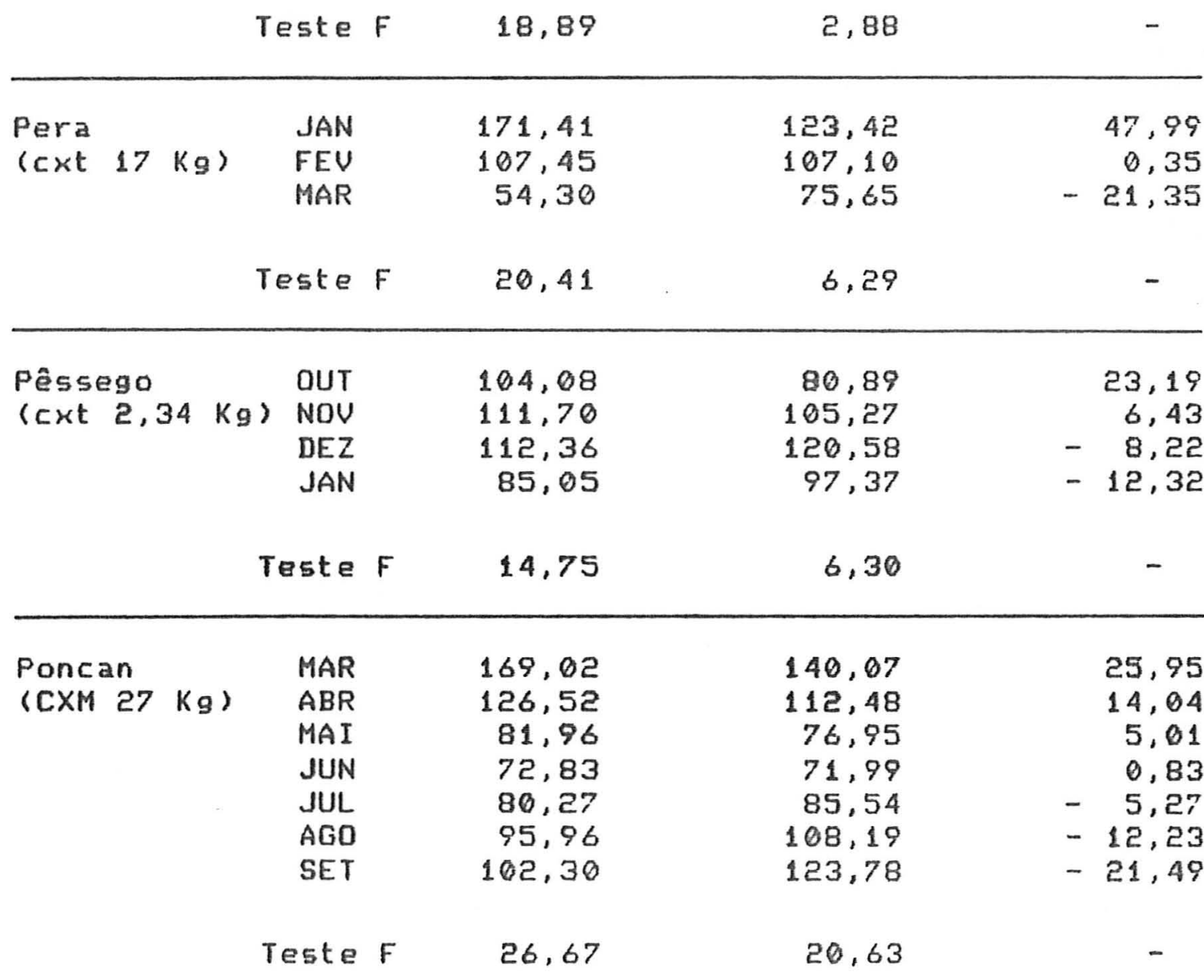


Tabela 4.1 - indices sazonais de precos correntes e deflacionados para 13 frutas comercializadas no atacado, e os testes $F$ obtidos. 1980-1988.

\begin{tabular}{|c|c|c|c|c|}
\hline \multirow{2}{*}{ Produto } & \multirow{2}{*}{ Meses } & \multicolumn{3}{|c|}{ indice Sazonal Médio } \\
\hline & & Corrente & Real & Diferenga \\
\hline \multirow{6}{*}{$\begin{array}{l}\text { Uva Niágara } \\
(c \times \quad 6,00 \mathrm{~kg})\end{array}$} & NOV & 243,44 & 174,63 & 68,81 \\
\hline & DEZ & 155,56 & 127,16 & 28,40 \\
\hline & JAN & 81,19 & 74,73 & 6,46 \\
\hline & FEV & 68,57 & 69.63 & $-1,06$ \\
\hline & MAR & 47,41 & 86,52 & $-39,11$ \\
\hline & este $F$ & 15,88 & 21,87 & - \\
\hline
\end{tabular}

FONTE: Dados primários da CEAGESP. 
Tabela 4.2 - indices sazonais obtidos a partir de precos reais e nominais a nivel do produtor e os Testes $F$ obtidos. 1980-1988.

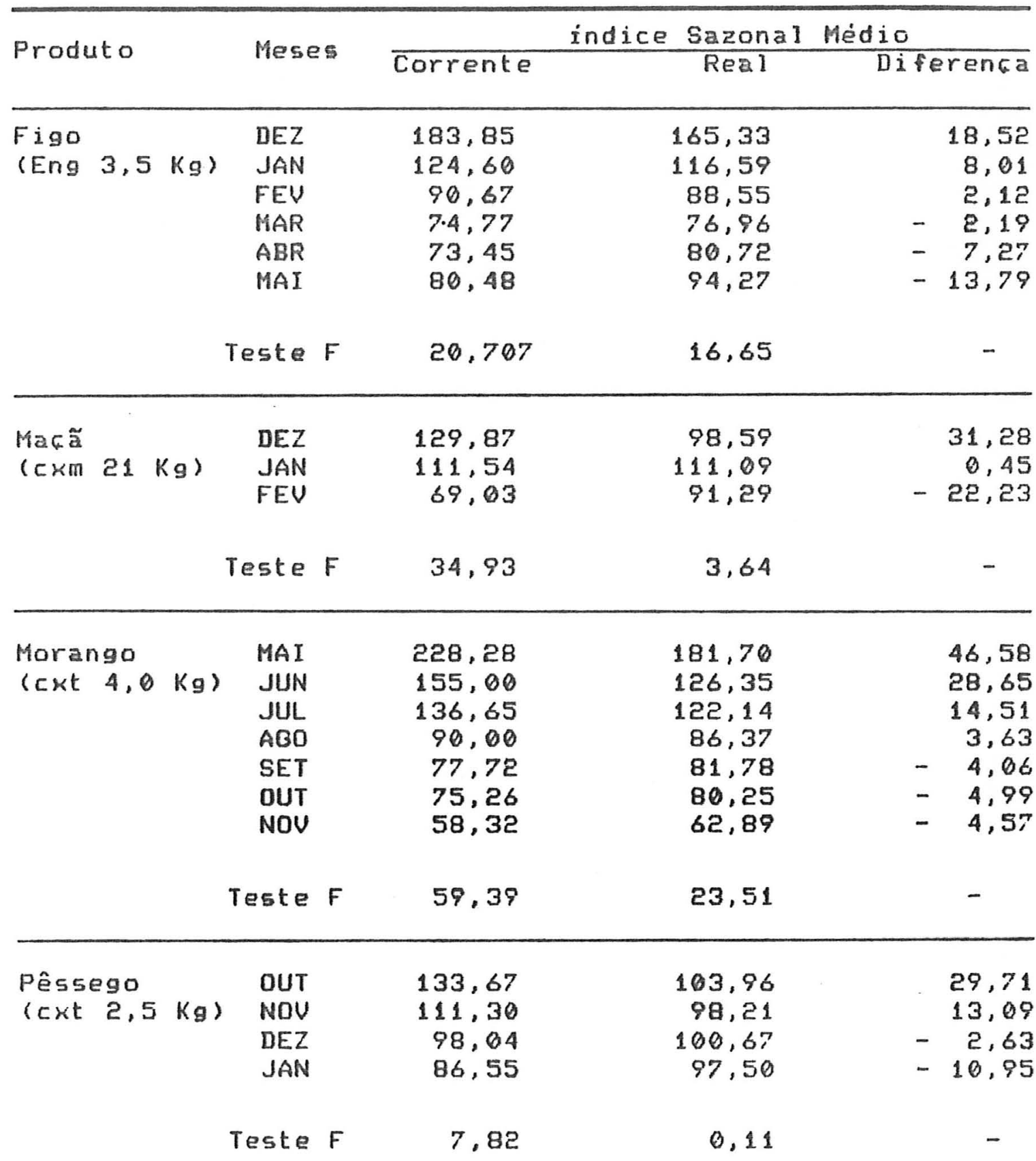


Tabela 4.2 - Indices sazonais obtidos a partir de precos reais e nominais a nivel do produtor e os Testes F obtidos. 1980-1988.

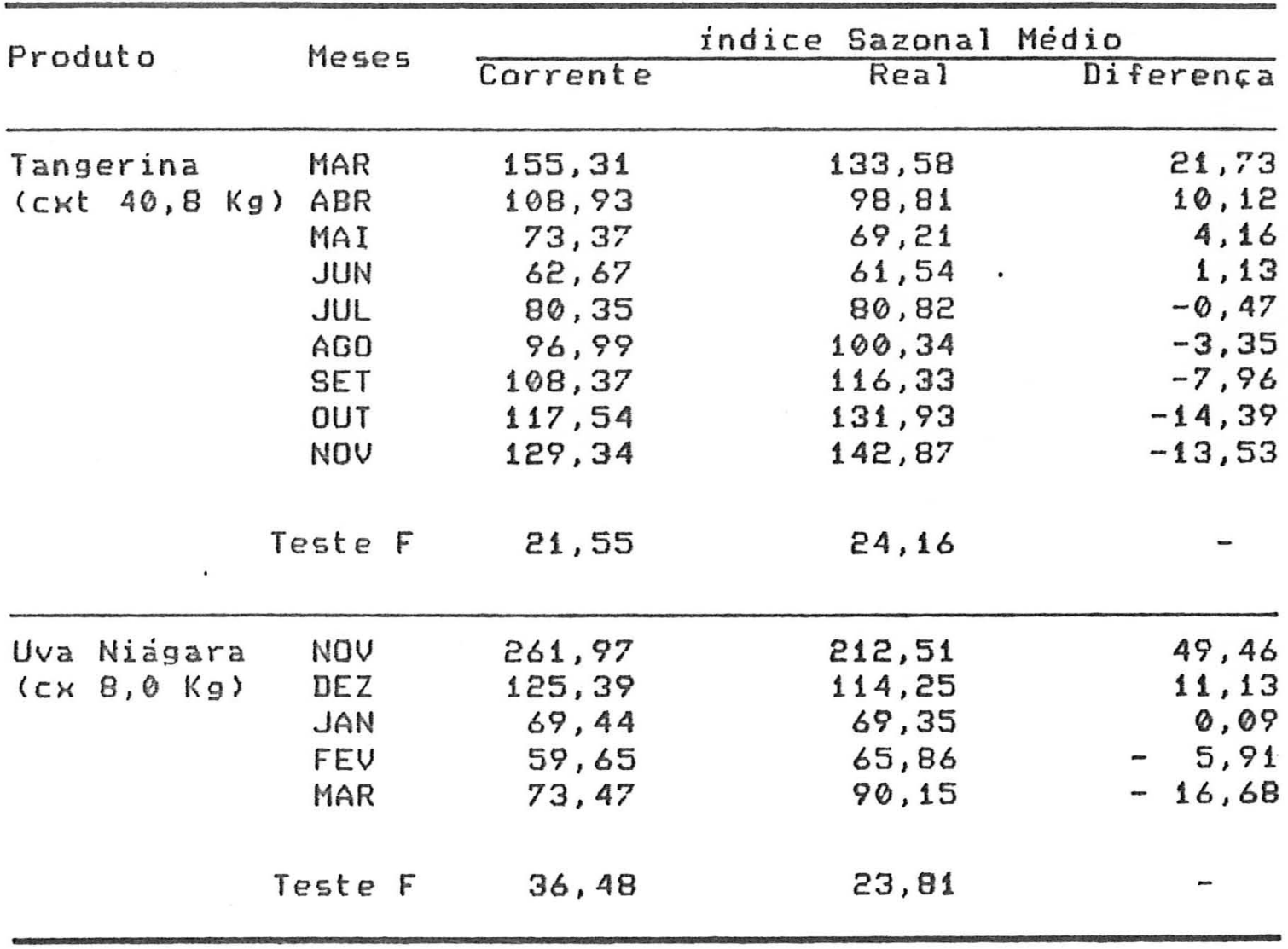

FONTE: Dados primarios da Secretaria da Agricultura e Abastecimento (Instituto de Economia Agricala). 
Foi calculado, também o teste $F$ que mostra a importância da variaç̃o estacional na variacão total de preco5.

$$
05 \text { resultados mostram que o teste } F \text { se }
$$
apresenta, em geral, mais elevado para frutas cujo indice foi calculado para valores nominais (ameixe, figo, manga, morango, nectarina, nêspera, pera, pêssego e tangerina poncan).

Uma vez que os indices estacionais para precos nominais estão subestimados nos meses iniciais e superestimados nos meses finais, a dispersão dos valores em relacão à média é maior para algumas séries de precos nominais, por isto o teste $F$ para os valores nominais destas frutas se mostrou mais elevado. Uma vez que os preços são deflacionados, ao corrigir as distorcões o valor deste teste reduz-se bastante para as frutas citadas. Assim, é importante destacar que quando se utiliza precos nominais, pode-se estar embutindo um componente inflacionário na estimativa do indice estacional como nos casos do figo, manga, nectarina, nêspera, pera e pêssego no mercado atacadista, e mą̧ã, morango e pêssego ao nivel do produtor.

0 teste $F$ capta também a diferenca de preqos dada pela inflação, o que não significa que tenha caracteristicas sazonais, como se define convencionalmente. 
Por outro lado, alguns produtos apresentaram - teste F maior para indices calculados para valores reais. Isto deve ocorrer porque o comportamento dos indices foi muito estável ao longo do ano, e assim ao se deflacionar os valores nominais corrigem-se as distorgóes, explicitando o componente estacional e isto torna o valor do teste $F$ maior como nos casos de mexerica, caqui, macã e uva niágara, no mercado atacadista; e a tangerina, a nivel do produtor.

A diferenca na intensidade dos indices estacionais pode ser ilustrada pelas figuras 4.1 e 4.2 que apresentam o comportamento estacional de precos nominais e reais para a mexerica (cxm - $27 \mathrm{Kg})$.

Estes gráficos mostram que a intensidade dos indices estacionais e precos difere bastante. Enquanto em termos nominais os precos são praticamente estáveis até agosto, caindo no mês de setembro; para os precos reais, no periodo de junho a agosto, os precos elevam-se de 78,19 para 119,69 e a partir dai permanecem relativamente estáveis.

Verificou-se também que o numero de meses de entressafra afeta a estimativa dos indices sazonais. De um modo geral, as diferencas entre os indices calculados para precos reais e precos nominais aumentaram com o numero de meses de entressafra, tanto para os meses do inicio de 
safra quanto para os meses de final de safra, conforme mostra a Tabela 4.3.

Os coeficientes dé correlacão foram calculados considerando o numero de meses da entressafrá como uma variável e o valor absoluto das inédias das diferencas entre indices estacionais para precos nominais e reais, como a outra variável.

Estas médias das diferencas foram calculadas para o primeiro e para o último mês da safra, pois são os que apresentam os maiores vieses, conforme mostrado anteriormente.

Tabelá 4.3 - Número de meses de entressafra e médja das diferencas entre os indices estacionais calculados para precos reais e precos nominais do primeiro e ultimo meses de safra.

Meses de entressafra

Média das diferencas

Mês inicial Mês final

\begin{tabular}{|c|c|c|}
\hline 2 & 6,16 & 10,96 \\
\hline 4 & 29,91 & 11,31 \\
\hline 5 & 29,38 & 17,31 \\
\hline 6 & 28.62 & 15,56 \\
\hline 7 & 33,63 & 30,64 \\
\hline$B$ & 50.54 & 30,38 \\
\hline Coeficiente de & 0,93 & 0,89 \\
\hline
\end{tabular}

FONTE: Dados primários da CEAGESP 
Dessa forma fica também confirmada a terceira hipotese formulada nesta secão, de que o número de meses da entressafra influi na intensidade dos desvios observada nos indices.

A principal conclusão desta seção é que o deflacionamento de precas deve preceder a aplicacão do método da média móvel, quando se trabalha com preqos de produtos que apresentam oferta restrita a poucos meses no ano principalmente em periodos de elevados indices inflacionários.

Os principais problemas que ocorrem quando se utiliza precos nominais nesta situacão $\dot{e}$ que os indices calculados podem estar viesados e o componente estacional pode estar super ou subestimado.

\subsection{Tendéncia}

Foi visto no item anterior que o deflacionamento de preços é recomendado em especial para produtos que apresentam oferta temporária. Esta correcão de precos evita vieses na estimativa dos indices estacionais dos meses iniciais e finais da safra.

0 deflacionamento de precos, entretanto, afeta o ajustamento da média móvel a funcões lineares exponenciais, como mostra a Tabela 4.4 
Tabela 4.4 - Coeficiente de determinacão do ajustamento da média móvel de precos reais e nominais à funcôes lineares e exponenciais.

\begin{tabular}{|c|c|c|c|c|}
\hline \multirow{2}{*}{ Frutas } & Precos & Nominais & \multicolumn{2}{|c|}{ Precos Reais } \\
\hline & F.Linear & F.Exponenc. & F.Linear & F. Exponenc \\
\hline Figo & 0.52 & 0.97 & 0,03 & 0,01 \\
\hline Mąã & 0.45 & 0.96 & 0,03 & 0,04 \\
\hline Morango & 0,40 & 0,98 & 0.07 & 0.03 \\
\hline Pêssego & 0,72 & 0,98 & 0,03 & 0,08 \\
\hline $\begin{array}{l}\text { Tangerina } \\
\text { Poncan }\end{array}$ & 0,40 & 0.98 & 0.61 & 0,54 \\
\hline Uva Niágara & 0,53 & 0.99 & 0,11 & 0.06 \\
\hline Caqui & 0,51 & 0,98 & 0,03 & 0,02 \\
\hline
\end{tabular}

FONTE: Dados primérios da CEAGESP.

Para prefos nominais, a tendencia da série ajusta-se melhor a uma funcão exponencial, pois parte da tendência é provocada por altas taxas inflacionárias. Dessa forma, quando se remove o componente inflacionario, o coeficiente de determinacão da série de precos reais às duas funcões se torna bastante reduzido.

$$
0 \text { objetivo deste capitulo é analisar o }
$$
comportamento tendencial dos precos após a remocão do componente inflacionário e verificar o modelo que melhor se aplica aos precos deflacionados.

$$
\text { Quando se corrige os precos, as seguintes }
$$

situacões podem ocorrer. 
1- 0s precos podem após, o deflacionamento, continuar apresentando uma tendência exponencià e periodicidade relativa, ou seja, a amplitude absoluta do componente estacional cresce com o nivel de precos. Neste caso, a utilizacão do modelo da média geométrica é a mais adequada para obtencão dos indices estacionais.

2- 05 precos, após o deflacionamento, podem apresentar uma tendência linear crescente ou decrescente e periodicidade absoluta. O modelo apropriado, nestes casos, é o da média aritmética.

o problema deste modelo é que apresenta os componentes estacionais na forma de desvios e não na forma de indices, que é mais comum. Pode-se, entretanto, transformar estes valores em um indice em relacão a uma base fixa, como o preço inicial, representado por "a" na equação.

$$
I E_{l}=\frac{d_{l}}{a} \times 100
$$

onde IE é o indice estacional, $d_{l} \dot{e}$ o desvio absoluto e "a" é preco inicial.

D tipo de tendência será analisado a fim de determinar o tipo de modelo que melhor se adequa as dados. Se a série apresentar crescimento linear, o método adequado 
é o da média aritmética. Se a série apresentar crescimento exponencial o método adequado é o da média geométrica.

0 tipo de periodicidade é mais dificil de determinar. Um exemplo onde a periodicidade relativa foi captada com facilidade é quando foram estimados os indices estacionais para precos nominais utilizando-se o primeiro modelo (da media aritmetica), que capta a amplitude absoluta. Observou-se para todas as frutas um crescimento acentuado dos indices estacionais. A Tabela 4.5 mostra os indices estacionais obtidos para o preco nominal de alguns produtas, utilizando-se este madelo.

A flutuacão de preços se dá em termos relativos, pois uma mesma variacăo absoluta pode ser tornar insignificante a niveis elevados de precos.

A análise da tendencia foi feita procurando-se ajustar a média aritmética móvel (M) a uma funcão linear do tipo.

$$
M_{t}=a+b t+u_{t}
$$

Procurou-se ajustar também o logaritmo da média geométrica dos precos $\left(G_{\mathfrak{l}}\right)$ a uma funcão logaritmica como se segue.

$$
\ln G_{l}=\ln A+\ln B+\ln u_{l}
$$


Tabela 4.5 - Variacão absoluta dos indices estaciorais de prefos nominais para algumas frutas no periodo de 1981 a 1987 .

\begin{tabular}{lccccccr}
\hline & 81 & 82 & 83 & 84 & 85 & 86 & 87 \\
\hline \multirow{2}{*}{ Figo } & 0,01 & 0,03 & 0,10 & 0,35 & 0,76 & 2,26 & 9,06 \\
Macä & 0,03 & 0,20 & 0,33 & 0,81 & 3,77 & 8,94 & 56,81 \\
Uva Fina & 0,37 & 0,70 & 1,34 & 3,64 & 14,34 & 35,55 & 108,13 \\
Tangerina & 0,05 & 0,16 & 0,52 & 1,58 & 5,86 & 9,55 & 70,53 \\
\hline
\end{tabular}

FONTE: Dados primários da CEAGESP.

0s ajustamentos foram feitos através de regressões lineares simples pelo método dos minimos quadrados ordinários e os resultados estatisticos obtidos são apresentados na Tabela 4.6. 
Tabela 4.6. Resultados da análise da tendência de preços de algumas frutas estacionais.

Média Aritmética (funçres lineares)

\begin{tabular}{lrrrl}
\hline Eruta & Parâmetro b & Teste $t$ & terítico & $\mathrm{R}^{2}$ \\
\hline Figo (eng-1,8 kg) & 0,33 & 1,48 & 2,01 & 0,03 \\
Maçấ (cx-21,0 kg) & $-6,07$ & 0,71 & 2,09 & 0,03 \\
Morango (ces-3,2 kg) & 8.91 & 5,18 & 1,98 & 0,07 \\
Pêssego (cxt-2,34 kg) & 3,78 & 1,12 & 2.03 & 0,03 \\
Poncan (cx-27,0 kg) & 24,13 & 112,12 & 1,98 & 0,61 \\
Nectarina (cxt-2,25kg) & 2,45 & 0,51 & 2,02 & 0,02 \\
Uva niagara (cx-6 kg) & $-2,57$ & 8,176 & 1,98 & 0,11 \\
\hline
\end{tabular}

Média geométrica (funçôes exponenciais)

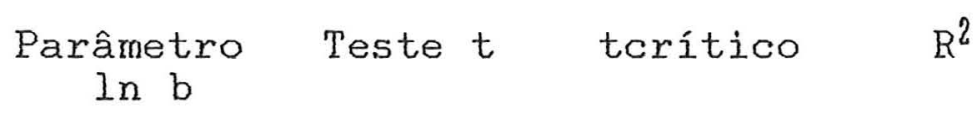

\begin{tabular}{lrrrl} 
Figo (eng-1,8 kg) & 0,001 & 0,57 & 2,01 & 0,01 \\
Maçã (cx-21,0 kg) & $-0,006$ & 0,89 & 2.08 & 0,04 \\
Morango (ces-3,2 kg) & 0,002 & 2,00 & 1,98 & 0,03 \\
Pêssego (cxt-2,34kg) & 0,006 & 0,03 & 2,03 & 0,08 \\
Poncan (cxm-27,0 kg) & 0,007 & 86,36 & 1.98 & 0,54 \\
Nectarina (cxt-2,25 kg) & 0,004 & 0,04 & 2,02 & 0,08 \\
Uva niagara (cx-6 kg) $-0,001$ & 3.62 & 1,98 & 0,06 \\
\hline
\end{tabular}

Eonte: Dados primários da Ceagesp. 
0s resultados apresentados na Tabela 4.6 mostram que os coeficientes de determinaça são reduzidas para ambas as funções, com exceça da tangerina para a func:a linear que apresantau $\mathrm{F}^{2}=0.61$ e para a funcão exponencial cujo $\mathrm{R}^{2}=0,54$.

Ds coeficientes reduzidos indicam que as séries não apresentaram crescimento significativo após o deflacionamento.

Para o morango e a uva niágara os coeficientes de determinacão ge mostraram bastante reduzidos, mas o teste $t$ foi significativo a nivel de $5 \%$. Isto indica que estas séries devem apresentar algum crescimento, embora menos acentuado que a tangerina que apresentou elevado $R^{2}$ e o teste $t$ significativo como mostram as Figuras 4.2.1,4.2.2 e 4.2.3.

Mesmo que as séries apresentem subperiodos, onde as tendências de crescimento sejam diferentes, observa-se que grande parte do movimento tendencial foi removido com o deflacionamento de $t a l$ forma que a utilizacăo de um ou outro método é indiferente. 

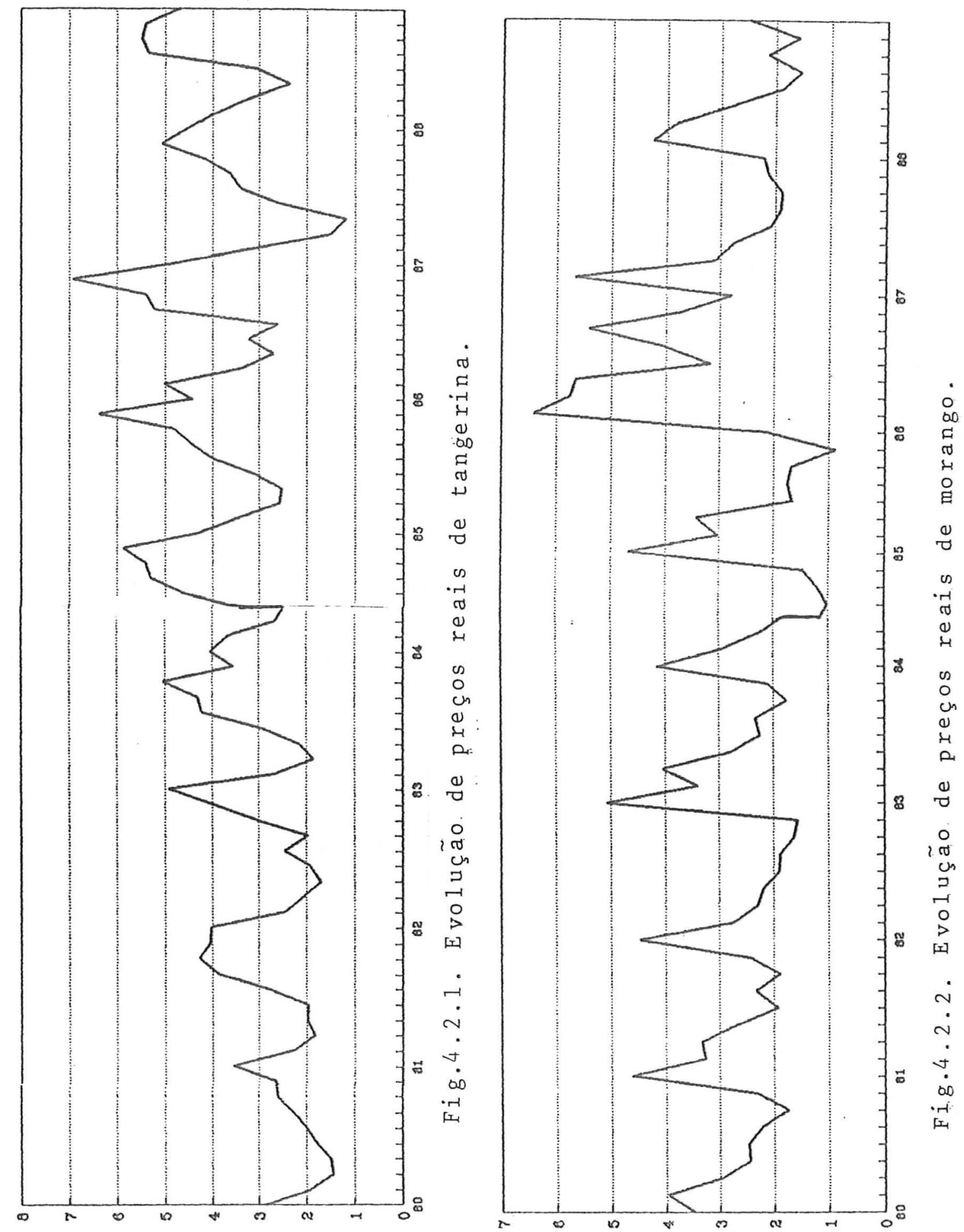
5,0

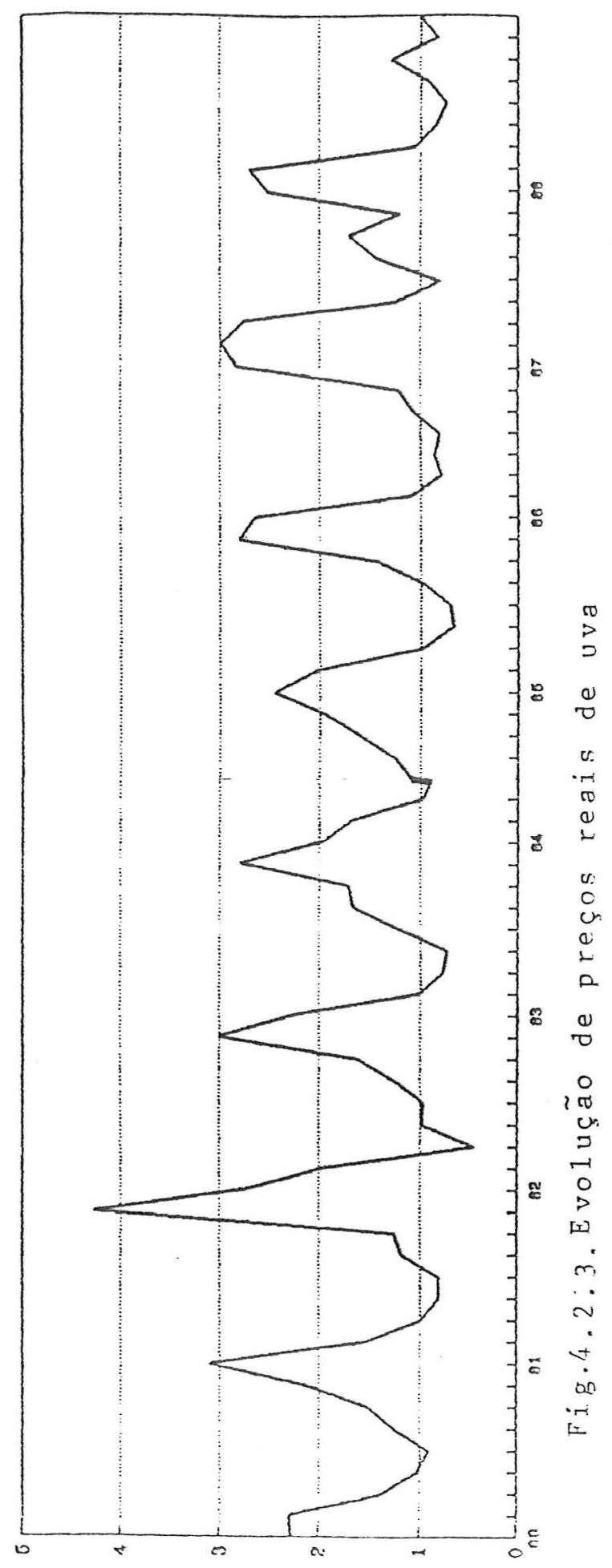


Não foram observadas alterăões importantes na amplitude absoluta dos componentes estacionais, uma vez que a inflarão, quando determina um aumento de pręos, aumenta também à amplitude absoluta dos indices estacionais. Se os precos são deflacionados, a amplitude absoluta dos indices estacionais se mantém constante.

Como as séries não apresentaram crescimento significativo ao longo do periodo, e a amplitude absoluta se mantém constante, o uso de qualquer um dos métodos é indiferente para estimar os indices estacionais.

Para este estudo utilizou-se o método da média geométrica por ser de uso generalizado, inclusive para a tangerina, pois o ajustamento para a funcão exponencial foi semelhante à funcão linear

\subsection{Ciclos}

A majoria dos, autores näo considera a existência de ciclos nas séries temporais, incluindo este componente junto à tendência.

Para culturas perenes ou semiperenes é razoável supor que os precos destes produtos podem apresentar uil movimento ciclico.

Alguns produtos têrm seu movimento ciclico berm definido, como é o caso do café, que apresenta ciclo de 
producão bienal. A producão de um ano afeta o desenvolvimento da planta no ano seguinte $e$ consequentemente há oscilac ão na producão.

Segundo BRANDT (1979) o mecanismo dos ciclos

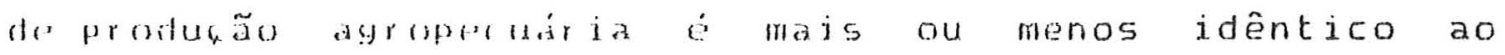
mecanjsmo dos ciclas econômicos que caracterizam as economias de liure empresa. Grande numero de produtores tomain decisôes independentes, inas são gujados principalmente por precos. O retardamento da producão em relacäo ao preco determina a extensâo minima do ciclo e é considerado como parte do mecanismo endógeno do ciclo. Os retardamentos psicológicos e econômicos fazem com que os ciclos sejam mais longos do que seria de se esperar do retardamento fisico.

Admitindo-se que o principal indicador para tomada de decisão dos produtores sejam os niveis de precos praticados, este indicador não existe nos períodos de entressafra para frutas com oferta estacional. 0 produtor tem como um sinalizador os precos praticados na uiltima safra e vaj. planejar sua producão de acordo com os últimos pregos cotados.

Se en determinado ano ( $t$ ) o nivel de prefos foi elevado, isto estimula os produtores a aumentar as despesas e cuidados em tratos culturais (controle de pragas, doencas, utilizacão de insumos e mão-de-obrà, 
provocando aumento da oferta do ano seguinte $(t+1)$ e consequentemente, há queda dé precos. Isto desestimulará os produtores a investir na producão no periodo seguinte ( $t+2)$ diminuindo a oferta do produto e aumentando os precos.

$$
\text { Pressupondo-se que o produtor não tem }
$$

conhecimento deste mecanismo, e que este processo repete-se sistematicamente, a série passa a apresentar um comportamento ciclico definido que é conhecido como "teoremax da teia de aranha"

Neste esstudo, para verificar a existência de movimentos ciclicos utilizou-se a série de precos pagos aos fruticultores, pois dessa forma fatores que possam mascarar a existência de ciclos, como quantidade advinda de outras regiôes, etc., nâo interferem nos resultados. Não se pretende afirmar que estes fatores não afetam o pręo ao nivel do produtor, mas a existência de ciclos biológicos é mais facilmente captada ao nivel do produtor. 0 modelo de análise de regressão utilizado por SATO (1988) foi usado para verificar a existência de ciclos nas séries temporais. 0s precos praticados pelos atacadistas provavelmente näo devem refletir os ciclos presentes na producão, pois estes precos refleten o abastecimento à CEAGESP durante todo o ano, contabilizando produtos que vêm de regiôes diferentes, produzidos em épocas diferentes. 
Para se verificar este comportamento ciclico, foram analisados os prequs coletados junto a produtor divulgados pelo IEA
A Tabela
4. 7
most ra
05
resultados

estatisticos obtidos para o modelo.

Tabela 4.7 - Resultados da análise estatistica para ciclos.

GL. $R^{2} \quad$ Teste $F \quad F C$ D.W.

residuo

$\begin{array}{llllll}\text { Figo } & 49 & 0,46 & 0,98 & 2,21 & 1,13 \\ \text { Mąã } & 18 & 0,27 & 1,52 & 3,16 & 0,99 \\ \text { Morango } & 42 & 0,58 & 0,14 & 2,25 & 0,56 \\ \text { Pêssego } & 30 & 0,18 & 0,36 & 2,53 & 0,91 \\ \text { Tangerina } & 63 & 0,52 & 0,22 & 2,04 & 0,58 \\ \text { Uva fina } & 35 & 0,69 & 1,17 & 2,49 & 1,38 \\ \text { Uva comum } & 56 & 0,80 & 0,79 & 2,11 & 1,59\end{array}$

FONTE: Dados primarios da Secretaria da Agricultura e Abastecimento (Instituto de Economia Agricola).

o teste F testa à hipótese Ho $=\gamma_{1}=x_{2}=\ldots$ $=\gamma_{n}=0$, onde a variável mede a diferenca de padrăo de variặäo estacional de precos de anos impares para años pares 
Se o teste for significativo confirma a existência da diferenca de um ano para outro, confirmando a existência de ciclos nos precos.

Os testes $F$ mostraram-se não significativos indicando que a hipotese de nulidade não deve ser rejeitada. e confirma a não existência de diferença entre padrão de variacão estacional de um ano para outro e, portanto, a existência de ciclos não foi confirmada para nenhum dos produtos.

$$
\text { É possivel que existam fatores que mascarem a }
$$
existência de ciclos, mas não foram consideradas neste estudo.

De acordo com os resultados obtidos não serão considerados movimentos ciclicos e o padrão de variąão estacional terá apenas um periodo. 
5. CONCENTRAÇZO DA COMERCIALIZAÇZO NO MERCADO ATACADISTA DE FRUTAS

Nesta secão são analisados os niveis de concentracão para parte das frutas estacionais comercializadas no mercado atacadista e para algumas frutas não estacionais para efeito de comparacão.

Diversos autores têm colocado a dificuldade de mensuracão da concentracão da producão (neste caso especifico, volume comercializadol nas firmas, existindo um consenso no sentido de que um indice especifico não consegue captar todas as nuances da concentracão nos mercados.

MARQUES \& AGUIAR (1989) destacam que um dos problemas existentes com o coeficiente de Gini, por exemplo, é o mesmo associado a todos os indices que pretendem resumir informacões de mercado, isto é, a dificuldade de se saber a participacão de cada empresa individualmente no mercado total. Além disso, um dado indice de Gini não reflete uma unica distribuicão de firmas no mercado. 
Neste caso as dificuldades foram contornadas no sentido de que dispõe-se de informacões da participacão de todas as firmas na comercializacão de cada fruta individualmente. Estes dados estratificados acham-se na Tabela 5.1.

Além disso, a utilizacão de outros indices contornam os problemas inerentes a cada indice isoladamente.

CAUES (1964) coloca as limitacões dos indices de concentraçัด CA e CB. Supondo 2 distribuicões onde as 4 principais firmas detêm $80 \%$ das vendas, estas distribuicões podem diferir em aspectos importantes tais como numero total de firmas no mercado, e como esta porcentagem de $80 \%$ é distribuida entre as 4 firmas principais. Apesar disto, este mesmo autor destaca que estes indices dão uma idéia bastante exata de posicão, comparativamente, na escala que vai da concorrencia perfeita até o monopolio puro, pois a maioria das industrias (neste caso o mercado) inclui tanto firmas grandes quanto pequenas, normalmente. Acredita-se que casos atipicos possam ser identilicados.

A seguir serão apresentados os indices de concentracão e desigualdade obtidos.
A Tabela
5. 1
mostra
2.5 distribuicões percentuais dos permissionários e dos volumes comercializa- 
dos segundo 7 estratos de porcentagem comercializada para 31 frutas no mercado atacadista de São Paulo em 1989.

$$
\text { Esta tabela mostra os dados num nivel }
$$

bastante grande de desagregacão. Através desta observa-se que grande porcentagem dos permissionarios concentra-se nos estratos inferiores enquanto os maiores volumes comercializados concentram-se nos maiores estratos. Este É - caso de frutas como: banana climatizada, mexerica, figo, uva itália e pera nacional - $17 \mathrm{~kg}$.

Outras frutas como laranja, manga (ckk-25kg), nectarina $(2,25 \mathrm{~kg}) e$ tangerina poncan também apresentam grande concentracão de permissionários nos estratos inferiores, mas o volume comercializado acha-se mais distribuido nos estratos intermediários, indicando que existe um grau maior de concorrência e concentraçăo menor na comercializacăo.

Finalmente existem frutas que apresentam percentual reduzido de permissionarios nos estratos inferiores e o volume comercializado concentra-se nos estratos superiores, parecendo indicar que existem apenas grandes atacadistas. A participacão destas frutas no setor como um todo é pouco significativa, portanto não existem exandes atacadistas quando se pensa em termos de mercado global de frutas. As frutas que apresentam estas caracteristicas săo manga (cxt-11,50) e ameika (ckk-25kg). 


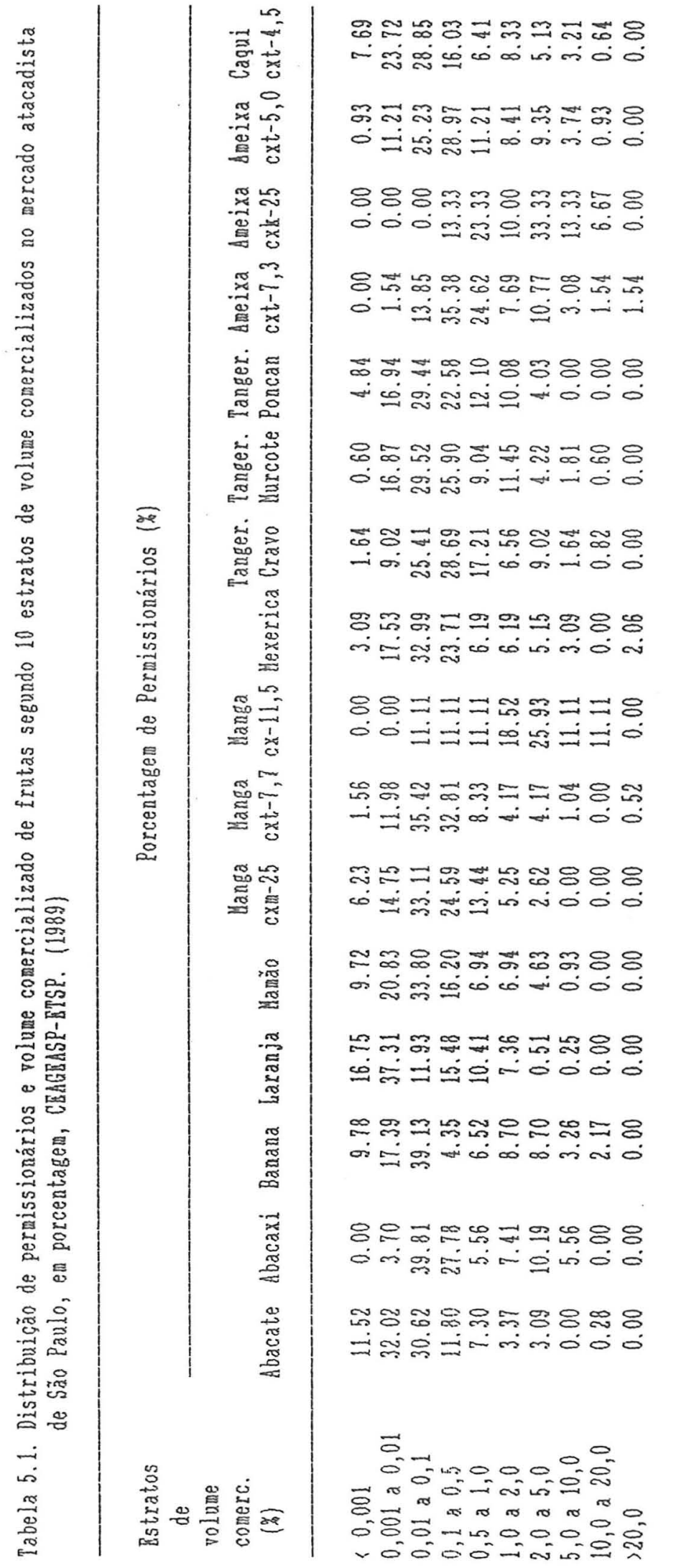

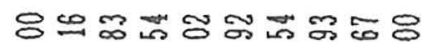
00-1

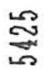

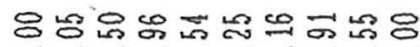
ல்-10்

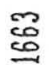

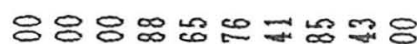
0000

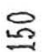

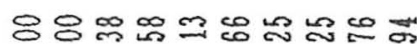
0000

$\stackrel{\infty}{m}$

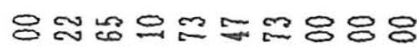

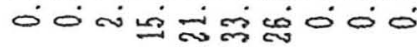
$\underset{\Xi}{\leftrightarrows}$

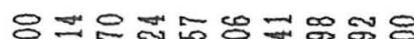
0ㅁ이요

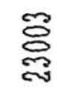

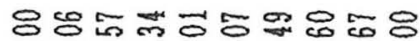
00-10 $\underset{8}{\mathscr{C}}$

8요에요용요용 0ं $\underset{\infty}{\infty}$

88:

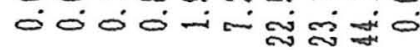
隶

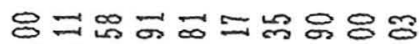

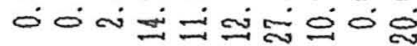

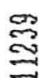

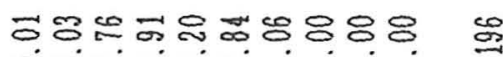
00 $\stackrel{\infty}{\Xi}$

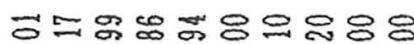
ம0-

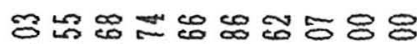
00-

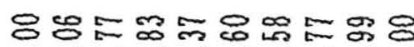
0000

突

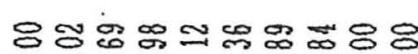
0ं

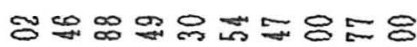

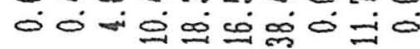




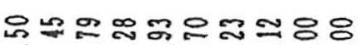

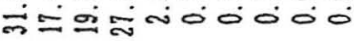

$\vec{\infty}$

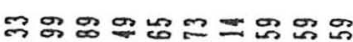

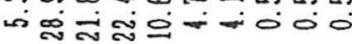

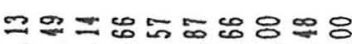

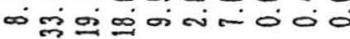

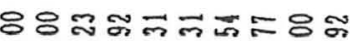

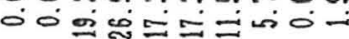

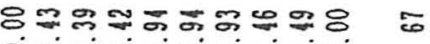

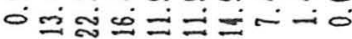

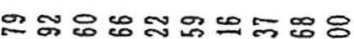

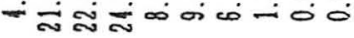

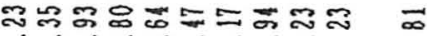

-

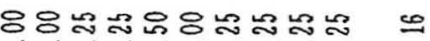

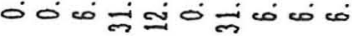

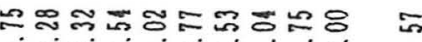

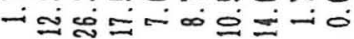

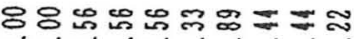

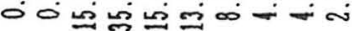

2

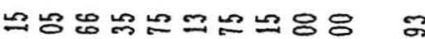

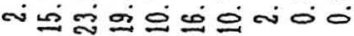

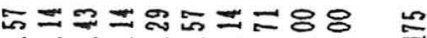

서에

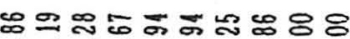

- ¿í

$\Xi$

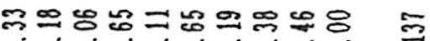

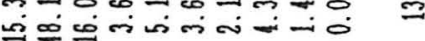

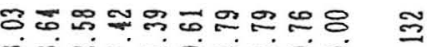

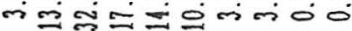

$\overline{0}=\overline{0}=00000$

范

00000
으윰퓨

000

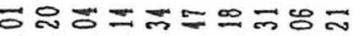

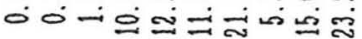

㤩

$\underset{\infty}{\infty}$

두듀요

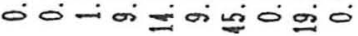

怘

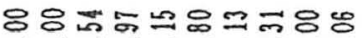

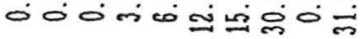

잉형으으으묘묭ㅇㅇ

00ं0ี

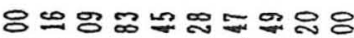

$00-\infty \infty \omega 5=0$

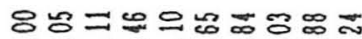

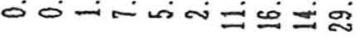

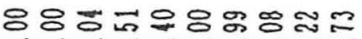

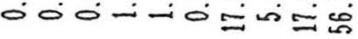

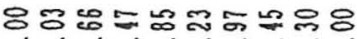

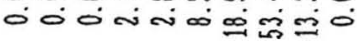

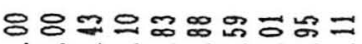
000-

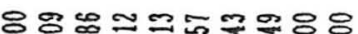
000

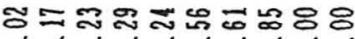

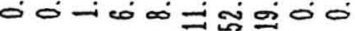

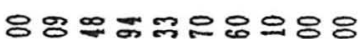
00

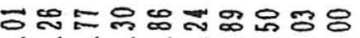
000-

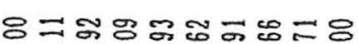

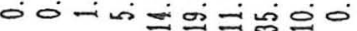

$$
\text { :- }
$$

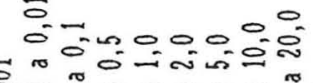

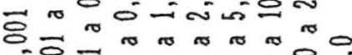

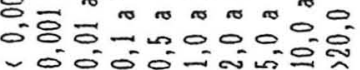

용

윤

$\bar{\Xi}$

$\stackrel{\infty}{\stackrel{\circ}{8}}$

点

요

음

:

$\stackrel{\infty}{9}$

$\stackrel{2}{\stackrel{2}{6}}$

怘

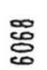

푱 용 
São frutas cuja forma de comercializacão difere da convencional, indicando uma tentativa de diferenciacão neste mercado.

A Tabelis 5.2 apresenta 05 resultados das medidas de concentracão e desigualdade para os produtos selecionados.

A Tabela 5.3 agrupa os resultados segundo os indices $C_{\&}$ e Hirschmann. Na horizontal as frutas foram agrupadas segundo as categorias de $C_{\text {t }}$ definidas anteriormente (atomizada, oligopólio de baiko grau, oligopólio concentrado, oligopólio altamente concentrado).

Em cada uma destas categorias os indices foram ordenados segundo a intensidade do indice de Hirschmann, sendo que as frutas com este indice mais elevado estão no alto de cada coluna.

Os resultados da Tabela 5.3 mostram que a maioria das frutas analisadas concentram-se na categoria de oligopolio de baixo grau, isto é, onde as 4 firmas principais detêm entre $25 \%$ e $50 \%$ do volume comercializado.

As frutas que apresentam comercializacão mais concorrencial sắ aquelas situadas na categoria de atomizadas, ou seja, manga (cxk-25kg), tangerina poncan $E$ laranja.

As frutas que apresentam a comercializacão mais concentrada são aquelas classificadas na categoria de 
Tabela 5.2. Indices de concentração da comercialização no exercado atacadista de frutas no Istado de São Paulo, CRdGBSP - Rntreposto Terninal (1989).

\begin{tabular}{|c|c|c|c|c|c|c|}
\hline Eruta & Dridade & GIMI & HIRSCHЕมH & $\mathrm{C4}$ & 88 & $\begin{array}{c}\text { Permissionários } \\
\text { (número\} }\end{array}$ \\
\hline
\end{tabular}

Iropicais

\begin{tabular}{|c|c|c|c|c|c|c|}
\hline Abacate & $c \times k-22,00 \mathrm{~kg}$ & 0.85479 & 0.03214 & 25.22 & 40.17 & 356 \\
\hline Abacaxi & cen $-155,00 \mathrm{~kg}$ & 0.77303 & 0.04647 & 33.56 & 53.34 & 108 \\
\hline Banana Clieat. & $\mathrm{cx}-21,00 \mathrm{~kg}$ & 0.85176 & 0.08669 & 50.68 & 69.81 & 92 \\
\hline Laranja & $c x=27,00 \mathrm{~kg}$ & 0.79325 & 0.01471 & 15.48 & 22.48 & 394 \\
\hline Kanão & $\operatorname{cxa}-34,00 \mathrm{~kg}$ & 0.83673 & 0.03611 & 27.48 & 14.09 & 216 \\
\hline \multirow[t]{3}{*}{ Hariga } & $\operatorname{cxp} 20-25,00 \mathrm{~kg}$ & 0.72528 & 0.01244 & 12.91 & 23.04 & 305 \\
\hline & $\mathrm{cxt}-7,70 \mathrm{~kg}$ & 0.79562 & 0.05921 & 35.92 & 49.94 & 192 \\
\hline & $\mathrm{cxa}-11,50 \mathrm{~kg}$ & 0.60502 & 0.09494 & 52.75 & 75.81 & 27 \\
\hline Hexerica & $\mathrm{c} \times 1 \mathrm{Q}-27,00 \mathrm{~kg}$ & 0.86823 & 0.12665 & $61.0 ?$ & 74.93 & 97 \\
\hline Tangerina-cravo & $\operatorname{cxp}-28,00 \mathrm{~kg}$ & 0.73233 & 0.05097 & 36.39 & 47.82 & 122 \\
\hline Tangerina-surcote & cxor- $-30,00 \mathrm{~kg}$ & 0.76945 & 0.03598 & 29.91 & 44.08 & 166 \\
\hline langerina-poncan & CX植-27,00 kg & 0.70834 & 0.01410 & 12.57 & 22.61 & 248 \\
\hline
\end{tabular}

Clina Tenperado

\begin{tabular}{|c|c|c|c|c|c|c|}
\hline \multirow[t]{3}{*}{ Ameixa } & $\mathrm{cxt}-7,30 \mathrm{~kg}$ & 0.72659 & 0.08776 & 50.48 & 67.54 & 65 \\
\hline & $\mathrm{cxk}-25,00 \mathrm{~kg}$ & 0.56031 & 0.08118 & 46.75 & 68.05 & 30 \\
\hline & $\mathrm{cxt}-5,00 \mathrm{~kg}$ & 0.74792 & 0.01731 & 34.30 & 50.72 & $10 ?$ \\
\hline \multirow[t]{2}{*}{ Caqui } & $\mathrm{cxt}-4,50 \mathrm{~kg}$ & 0.82550 & 0.04581 & 34.05 & 51.53 & 156 \\
\hline & $\mathrm{cxk}-26,00 \mathrm{~kg}$ & 0.77381 & 0.04565 & 35.50 & 51.59 & 132 \\
\hline ligo & eng-1,80 kg & 0.91353 & 0.09363 & 49.03 & 75.50 & 137 \\
\hline Haçã nacional & $\mathrm{cx}-21,00 \mathrm{~kg}$ & 0.81474 & 0.04152 & 30.02 & 50.54 & 144 \\
\hline Horango & $\mathrm{cxt}-3,20 \mathrm{~kg}$ & 0.83354 & 0.03504 & 24.78 & 43.02 & 175 \\
\hline \multirow[t]{2}{*}{ Mectarina } & $\mathrm{cxt}-6,50 \mathrm{~kg}$ & 0.76801 & 0.13140 & 63.58 & 80.54 & 93 \\
\hline & $\mathrm{cxt}-2,25 \mathrm{~kg}$ & 0.77306 & 0.02143 & 20.44 & 31.82 & 45 \\
\hline Hêspera & $c x t-2,34 \mathrm{~kg}$ & 0.72974 & 0.06303 & 37.54 & 61.51 & 57 \\
\hline \multirow[t]{2}{*}{ Pera nacional } & $\mathrm{cx}-17,00 \mathrm{~kg}$ & 0.83880 & 0.13154 & 60.15 & 74.29 & 16 \\
\hline & $\mathrm{cxt}-3,00 \mathrm{~kg}$ & 0.76162 & 0.36130 & 83.58 & 97.01 & 81 \\
\hline \multirow[t]{2}{*}{ Pêssego } & $\mathrm{cxt}-2,34 \mathrm{~kg}$ & 0.81155 & 0.06459 & 41.67 & 54.42 & 146 \\
\hline & $c x e-10,00 \mathrm{~kg}$ & 0.71700 & 0.05377 & 36.78 & 56.76 & 67 \\
\hline \multirow[t]{2}{*}{ Ova niagara } & $\mathrm{cxt}-3,50 \mathrm{~kg}$ & 0.73467 & 0.12839 & 57.29 & 71.46 & 52 \\
\hline & $\mathrm{cxt}-6,00 \mathrm{~kg}$ & 0.83292 & 0.05329 & 32.28 & 44.38 & 209 \\
\hline Ova itália & $\mathrm{cxt}-8,00 \mathrm{~kg}$ & 0.84788 & 0.08890 & 47.15 & 60.21 & 169 \\
\hline Setor de frutas & - & 0.76375 & 0.00861 & 13.04 & 17.73 & 854 \\
\hline
\end{tabular}

Ronte: Bados priqúrios da CELGESP-RTSP.

cats=caixa querosene; cem=cento; cx=caixa; cxa=caixa de mercado; cxd=caixa dupla; cxt=caixeta eng=engradado. 
Tabela 5.3-Resultados de medidas de concentração agrupadas por C4 e ordendas pelo indice de Hirschnan.

64

$0<C 4<25 \quad 25<C 4<50 \quad 50<C 4<75 \quad 75<C<<100$

\begin{tabular}{|c|c|c|c|c|c|c|}
\hline Prod. Hir & schmana & Prod. & schmann & Prod. Hirse & huan & Prod. Hirschnarn \\
\hline Yorango & $(0.03504\}$ & Rigo & $(0.09363)$ & Pera 17 & (0. 13154$\}$ & Pera $3,0(0.36130\}$ \\
\hline Nectarina & $(0.02143\}$ & Jya Itália & $(0.08890\}$ & Mectarina 6.5 & $(0.13140)$ & \\
\hline Laranja & $(0.01471)$ & k跳ixa 7.3 & $(0.08776)$ & Bva 3,0 & $(0.12839)$ & \\
\hline T. Poncan & $\{0.01410\}$ & breixa $25 \mathrm{~kg}$ & $(0.08118\}$ & Kexerica & $(0.12565)$ & \\
\hline Kanga $25 \mathrm{~kg}$ & $(0.01244\}$ & Péssego 2.34 & $(0.06459\}$ & Manga 11 & $(0.09494\}$ & \\
\hline Setor & $(0.00861)$ & Mêspera & $\{0.06303\}$ & Bällatia & $(0.08669)$ & \\
\hline & & Manga $7.7 \mathrm{~kg}$ & $(0.05921)$ & & & \\
\hline & & Pêssego 10 & $(0.05377)$ & & & \\
\hline & & Dya 6 & $(0.05329)$ & & & \\
\hline & & P. cravo & $(0.05097)$ & & & \\
\hline & & dmeixa $5 \mathrm{~kg}$ & $(0.04731)$ & & & \\
\hline & & tbacaxi & $(0.04647)$ & & & \\
\hline & & Caqui $4 \mathrm{~kg}$ & $\{0.04581\}$ & & & \\
\hline & & Caqui $26 \mathrm{~kg}$ & {$[0.04565\}$} & & & \\
\hline & & Kaçã Hac. & $\{0.04152\}$ & & & \\
\hline & & 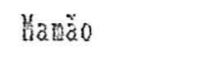 & $(0.03611)$ & & & \\
\hline & & i. Eurcote & $(0.03598)$ & & & \\
\hline & & Abacate & $(0.03214)$ & & & \\
\hline
\end{tabular}


oligopolio concentrado e oligopólio altamente concentrado, ou seja, pera $(c x-17,0 k g)$, nectarina (ckk-6,5kg), uva $(c x k-3,50 k g)$, mexerica $(c x m-27 \mathrm{~kg})$, manga $(11,5 \mathrm{~kg})$ e banana, na primeira categoria e pera (ckk-3,okg), na segunda.

Uma das razões que podem explicar o alto grau de concentracăo na comercializaça destas frutas é à concentracão da producão em determinadas regiões. Na safra de 1989, por exemplo, para pera, os municipios de Guapiara e Pilar do sul detiveram 52\% da producão; para a nectarina, os municipios de Mairinque e Marilia detiveram $71 \%$ da produção; uva, nos municipios de São Miguel Arcanjo, Indaiatuba e Jundiai, com $60 \%$ da producăo; mexerica, nos municipios de Pariqueracu, Registro, Capela do Alto e Mogi Guacu, detêm $70 \%$ da producão.

o figo e a uva itália se situam na categoria de oligopolio de baixo grau e apresentam o indice de Hirschmann relativamente elevado. A producão destas frutas também è relativamente concentrada. O figo teve $91 \%$ de sua producão obtida nos municipios de Valinhos e Campinas e a uva itália teve $70 \%$ de sua producão nos municipios de São Miguel Arcanjo e Pilar do Sul, ná $5 a$ fra de 1989.

A necessidade de infraestrutura de comercializaça pode ser um fator que facilita a concentraça jó 
que seu 450 implica em custos adicionais para os comerciantes.

As frutas de clima temperado tendem a apresentar maior concentracão na comercializacão em comparacăo com as frutas tropicais, especialmente por se tratar de frutas estacionais e de producão fortemente regionalizada. Além disso, a armazeñagm a frio necessária para estas frutas pode concentrar ainda mais a comercializacão.

Na categoria atomizada, encontram-se frutas cuja comercializaçă é atomizada, isto é, os 4 principais atacadistas detêm entre $0 \%$ e $25 \%$ da comercializacão. Neste grupo as frutas com mais baixo grau de concentracão são laranja, tangerina poncan e manga.

Dutras frutas como abacate, tangerina murcote e mamão, apesar de apresentarem $C_{\text {s mais elevado que }}$ as frutas anteriores também apresentam baixos indices de Hirschmann. Tanto estas como as frutas mencionadas anteriormente (laranja, tangerina poncan e manga) apresentam um grande número de permissionários, o que pode atuar como um fator que estimula a concorrência.

Relacionando-se os indices $C_{4}$ e $C_{6}$, como feito anteriormente para $C_{\&} e$ Hirschmann os resultados obtidos mostram-se semelhantes.

Pela Tabela 5.2 observa-se que o indice concentracăo no setor de frutas é inferior ao indice obtido 
por cada fruta, indicando tratar-se de um mercado relativamente especializado, onde cada comerciante trabalha com um numero limitado de produtos.

A Tabela (5.4) a seguir mostra os resultados relacionando os indices $C_{4} e$ Gini. Pode-se observar que os indices de concentracão e desigualdade não estão relacionados, ou seja, frutas que apresentam elevada concentracão podem não apresentar indice elevado de desigualdade. Isto se verifica para abacate, mamão, caqui (ckk-4,5kg), macã, morango, nectarina (ckk-2, 25kg).

Isto indica que estes produtos possuem em sua comercializacão um grande numero de permissionários que trabalham com um volume reduzido destas frutas, ao mesmo tempo em que não existem grandes atacadistas, que atuam na comercializacão destas frutas (ver Tabela 5.1).

Uma vez que se trata de um mercado especializado, a existência de atacadistas que trabalham com um volume muito pequeno de uma fruta, pode não indicar um pequeno permissionário, pois este pode ser um grande atacadista por outro produto. Dessa forma os indices de concentracão refletem melhor a distribuicão da comercializacão entre os permissionários deste mercado.

As principais conclusões que podem ser tiradas deste capitulo são: a) a comercialização das frutas no mercado atacadista é relativamente concentrado, onde grande 
Pabela 5.4 - Resuliacos de nedidas de concentração agrupadas por C4 e ordenadas pelo Indice de Gini.

\section{C4}

$0<04<25$

$25<C 4<50$

$50<C 4<75$

$75<C 4<100$

\begin{tabular}{|c|c|c|c|c|c|c|c|}
\hline Prod. & & Prod. & & Gini & & Prod. & Gini \\
\hline Horango & $(0.83354\}$ & Rigo & $(0.91353)$ & kexerica & $\{0.86750\}$ & Pera 3 & $(0.96162)$ \\
\hline Laranja & $(0.79325)$ & Abacate & (0.85479) & Banana & $(0.85176)$ & & \\
\hline Hectarina & $(0.79306)$ & Ora Itólia & $(0.84788)$ & Pera 17,0 & $(0.83880)$ & & \\
\hline Manga 25 & $\{0.75528\}$ & ห้อ & $(0.83073)$ & Hectarina 6.5 & $\{0.76801\}$ & & \\
\hline 1. Poncan & $\{0.70834\}$ & By 0,0 & $\{0.83292\}$ & Bva 3,0 & $(0.93467\}$ & & \\
\hline & & Caqui 4,0 & $\{0.82550\}$ & Karige 11 & (0.60502) & & \\
\hline & & Haçã Rac. & $(0.81474)$ & & & & \\
\hline & & Pêssego 2.3 & $\{0.81155\}$ & & & & \\
\hline & & Hanga 7.7 & $(0.79562\}$ & & & & \\
\hline & & Caqui 26 & $(0.77381\}$ & & & & \\
\hline & & T. murcote & $(0.76945)$ & & & & \\
\hline & & sneixz 5,0 & $(0.74792)$ & & & & \\
\hline & & T. cravo & $(0.73233)$ & & & & \\
\hline & & lêspera & $(0.72974)$ & & & & \\
\hline & & theixa 7.3 & $(0.72659)$ & & & & \\
\hline & & Pêssego 10 & $(0.71700)$ & & & & \\
\hline & & boeixa $25 \mathrm{~kg}$ & $(0.56031)$ & & & & \\
\hline
\end{tabular}


parte delas enquadra-se na categoria de oligopólio de baiko grau; b) é um mercado relativamente especializado, onde cada comerciante trabalha com um numero limitado de produtos; c) as frutas de clima temperado tendem a apresentar maiores niveis de concentracão na comercializacão; d) as frutas que apresentavam maiores desigualdades nem sempre apresentavam maiores concentracões, mas por se tratar de um mercado especializado, os indices de concentracão refletem melhor a distribuicão do volume comercializado. 
6. DETERIIINAÇAO DO PADRAOO DE VARIAÇX̃O ESTACIONAL DE PREÇOS E QUANTIDADES

Esta seç̃o tem como objetivo determinar o padrão de variacão estacional de preços e quantidades procurando identificar os fatores que o afetam. 0s indices de variacão estacional foram estimados utilizando-se a média geométrica móvel centralizada para o periodo de 1980 a 1988, a partir de precos deflacionados do mercado atacadista de São Paulo ao nivel do produtor.

Foram analisadas as seguintes frutas no mercado atacadista: ameixa, caqui, figo, macã, manga, mexerica, morango, nectarina, nêspera, pera, pêssego, tangerina poncan e uva niágara, segundo o prefo e a quantidade comercializada. A nivel do produtor foram analisadas apenas figo, macă, morango, tangerina, pêssego e uva niágara.

6.1. Ameixa

As ameixas são plantas da familia Rosaceae, gênero Prunus. Até 1970, as cultivares existentes no estado 
eram bastante exigentes em frio, e por isso apresentavam baixa produtividade, exceto nas regiões serranas. 0 lancamento da cultivar Carmesim contribuiu para o aumento da oferta por ser pouco exigente em frio e apresentar boa conservaçăo em câmaras frias.

No Estado de São Paulo, os principais municípios produtores são Mogi das Cruzes (1125 t), Sorocaba (600 t), e Pilar do sul (502 t). Estes três municipios foram responsáveis por $40 \%$ da producão do estado no ano de 1989.

A ameixa nacional comercializada no Estado de São Paulo é originára principalmente dos Estados do Paraná, São Paulo e Santa Catarina, mas a maior parte da fruta comercializada no atacado (75\%) tem origem estrangeira principalmente Argentina e Chile.

Conforme mostra a Figura 6.1, o pico de precos se verifica no mês de dezembro (IS $=132,29$ ) e o mês de novembro é o de mais baikos preços (IS $=79,49$ ). 0 teste F mostra que a estacionalidade não é importante na variação de precos ( $F=2,07)$, ao passo que a quantidade ofertada apresenta o componente estacional mais acentuado que os precos $(F=12,13)$.

0 Pico da comercialização de ameixa se verifica no mês de dezembro, (IS = 226, 13), coincidindo com - Pico dos pregos.

Até a mês de novembro, ao mesmo tempo em que 
a oferta aumenta, os precos caem. De novembro a janeiro precos e quantidades têm movimentos similares, cujos picos se verificam em dezembro. Isto pode ser explicado não só pelas festas natalinas, onde se verifica aumento da demanda mas também pelo fato de ser uma época de altas temperaturas quando o consumo de frutas é elevado, impedindo que as precos caiam, a despeito da elevada quantidade ofertada.

A partir de janeiro a quantidade ofertada diminui e os precos se recuperam (Figura 6.1 e Tabela 6.1 ). 


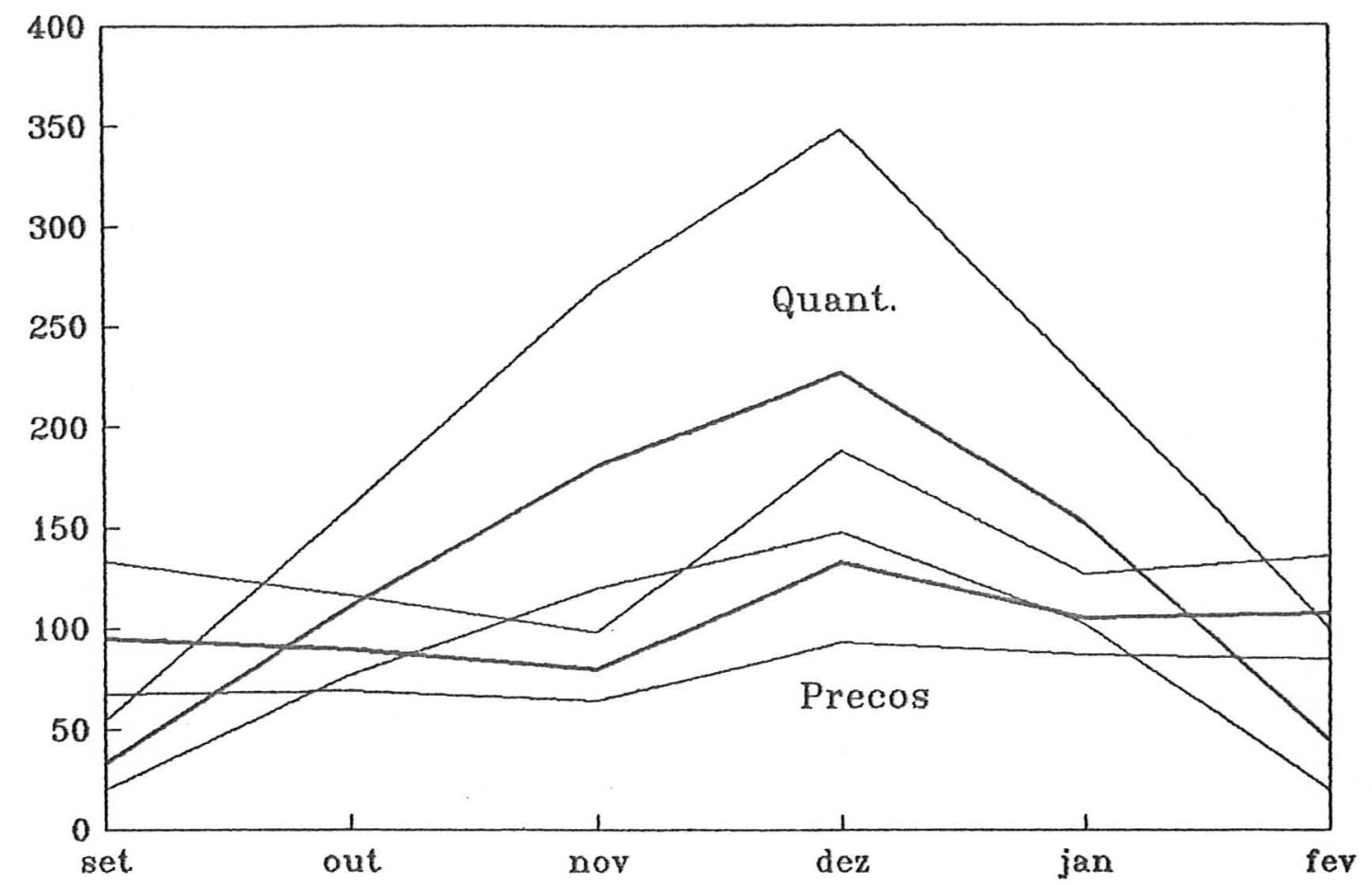

Figura 6.1 - Variąão estacional de precos deflacionados e quantidades de ameixa no mercado atacadista de São Paulo.

Tabela 6.1 - indices de variacão estacional de preços deflacionados e quantidades de ameixa (cxt-7,30 kg) no mercado atacadista de São Paulo. Periodo 1980-1988.

\begin{tabular}{lcrrrrr}
\hline MEsEs & \multicolumn{2}{c}{ Inferior } & \multicolumn{2}{c}{ Médio } & \multicolumn{2}{c}{ Superior } \\
& Preco & Quant. & Preco & Quant. & Preco & Quant. \\
\hline Setembro & 67,72 & 20,15 & 95,02 & 33,03 & 133,32 & 54,13 \\
Outubro & 69,14 & 77,17 & 89,68 & 110,93 & 116,31 & 159,47 \\
Novembro & 64,37 & 119,70 & 79,49 & 179,64 & 98,17 & 269,59 \\
Dezembro & 93,20 & 146,91 & 132,29 & 226,13 & 187,78 & 348,06 \\
Janeiro & 86,79 & 101,61 & 104,55 & 150,81 & 125,94 & 223,82 \\
Fevereiro & 84,54 & 20,6 & 106,74 & 44,54 & 134,77 & 98,87 \\
Teste F & - & - & 2,07 & 12,13 & - & - \\
\hline
\end{tabular}


82.

6. . . Caqui

o caqui pertence à familia das Ebenaceas que

possui plantas de valor econômico e ornamental. Esta cultura vem despertando grande interesse por parte dos fruticultores, tendo em vista os elevados rendimentos que proporciona. Em regiões propicias ela é importante porque permite o aproveitamento dos fatores de producão disponiveis no periodo de fevereiro a junho.

- consumo de caqui aumentou a partir de 1979, com a producão de frutas não taninosas, que tem a preferência do consumidor.

A produção braslleira de caquis destina-se quase que totalmente ao consumo in notura. 0 aproveitamento industrial do caqui para passas e vinagre é ainda incipiente.

A microrregião da Grande São Paulo respondeu por 58\% do volume comercializado no mercado atacadista durante o ano de 1989, sendo que os principais municipios produtores 5ão Mogi das Cruzes (6.500 t), Biritiba-Mirim (1196 t) e Itupeva (806 t).

Pela Figura 6.2 observa-se que os indices sazonais de precos são decrescentes até abril quando atingem o indice de 73,39 e a partir dai elevam-se até o final da safra em junho (IS $=160,22$ ). 0 componente 
estacional não é importante na variacão de preços (F = 5,71).

As quantidades apresentam componente estacional mais forte que os precos ( $F=12,94)$.

0 pico da comercializacão se localiza no mês de marco (IS $=210,36$ ) e o pico de precos se verifica nos mês de junho (IS $=160,22$ ). Neste mês a quantidade ofertada é reduzida (IS $=20,35$ ).

A queda na quantidade ofertada em junho e a pouca oferta de frutas em geral ocasionam a grande recuperação dos preços no final da safra.

Assim, o melhor periodo para o consumo do caqui é o mês de abril que é o mês de menores precos, ao passo que o mês de junho é o melhor mês para a comercialização no atacado.

A Figura 6.2 mostra também que a quantidade ofertada apresenta maior irregularidade que os precos. 


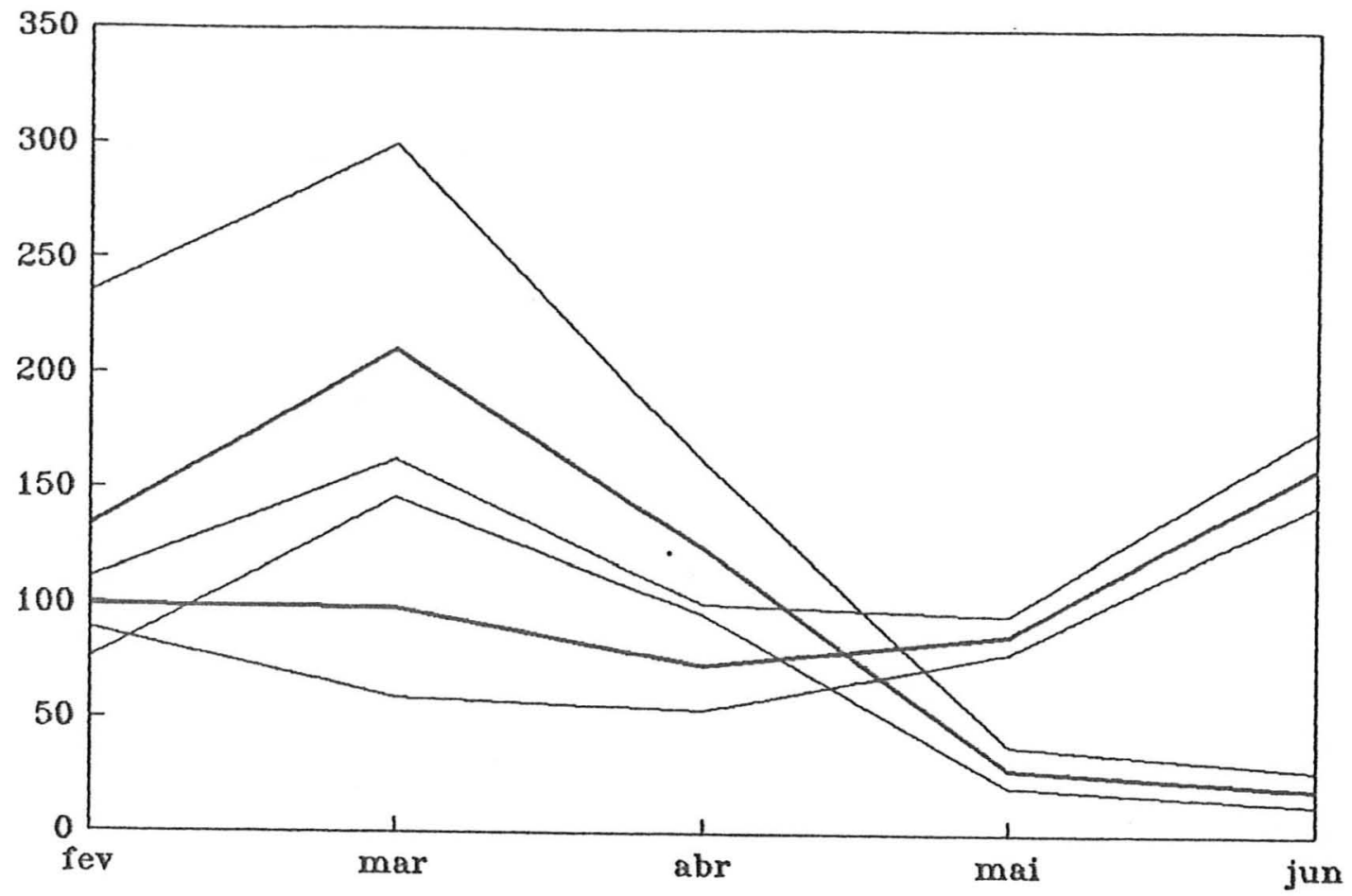

Figura 6.2 - Variação estacional de precos deflacionados e quantidades de caqui no mercado atacadista de São Paulo.

Tabela 6.2 - Indices de variacão estacional de precos deflacionados e quantidades de caqui (cxt-4,50 kg) no mercado atacadista de São Paulo. Periodo $1980-1982$.

MESES

Inferior

Médio

Superior

Preco Quant. Preco Quant. Preco Quant.

\begin{tabular}{lrrrrrr} 
Fevereiro & 88,99 & 75,85 & 99,22 & 133,63 & 110,64 & 234,98 \\
Marco & 59,29 & 146,12 & 98,19 & 210,36 & 162,60 & 299,31 \\
Abril & 53,66 & 95,70 & 73,39 & 124,50 & 100,37 & 161,96 \\
Maio & 79,37 & 20,94 & 87,29 & 28,57 & 96,01 & 38,96 \\
Junho & 144,81 & 13,64 & 160,22 & 20,35 & 177,26 & 28,56 \\
Teste F & - & - & 5,71 & 12,94 & - & - \\
\hline
\end{tabular}




\subsection{Figo}

o figo é uma planta pertencente à familia Moracede, gênero Ficus. É uma cultura que apresenta vantagens no aspecto da comercializacăo, pois tem grande aceitacão na forma in natura e o excedente da producão pode ser dirigido à industria para obtencão de massa ou figo rami. o figo verde também tem grande demanda por parte da indústria para obtencão do doce em calda.

No Estado de São Paulo, a cultura desenvolveu-se no municipio de Valinhos que respondeu por $83 \%$ da producão (5250 t) na safra de 1984. 0 segundo principal municipio é Campinas que detém $13 \%$ da producão. Dado o encarecimento do valor das terras nesta regiăo as culturas para industria deslocaram-se para outros municipios como Angatuba, Buri e Brodósqui.

Pela Figura 6.3 e Tabela 6.3 verifica-se que - maior indice de precos é observado no inicio da safra $($ IS $=145,26)$ e são decrescentes até abril (IS $=77,26$ ). No - final do periodo de oferta, em maio, os precos recuperam-se ligeiramente.

A importância da estacionalidade é maior na quantidade ofertada $(F=108,26)$ que nos precos $(F=18,00)$. Ds meses de janeiro e fevereiro apresentam os maiores volumes comercializados, ( $I S=356,60 \mathrm{e}$ 
IS $=344,51$, respectivamente). A partir do mês de janeiro reduz-se significativamente atingindo o indice de $23,38 \mathrm{em}$ juntio.

De dezembro a janeiro a queda de precos pode ser explicada pelo grande aumento da quantidade ofertada.

Nos meses de janeiro e fevereiro a quantidade ofertada ainda é alta, mas decrescente, ao mesmo tempo que os prefos também caem. Isto ocorre por ser uma época de constante precipitacão $e$ ataque de fungos que compromete a qualidade da fruta.

A partir de abril os precos se recuperam pois a quantidade ofertada continua a diminuir.

Podem ser verificadas grandes semelhancas no padrão de variacão estacional de precos ao produtor $e$ no atacado (Figuras 6.3 e 6.3.1).

Mesmo o componente estacional é bastante semeihante para os precos do produtor $e$ ao atacado $(F=16,65$ e $F=18,00$, respectivamente), como mostram as Tabelas 6.3 e 6.3 .1$. 


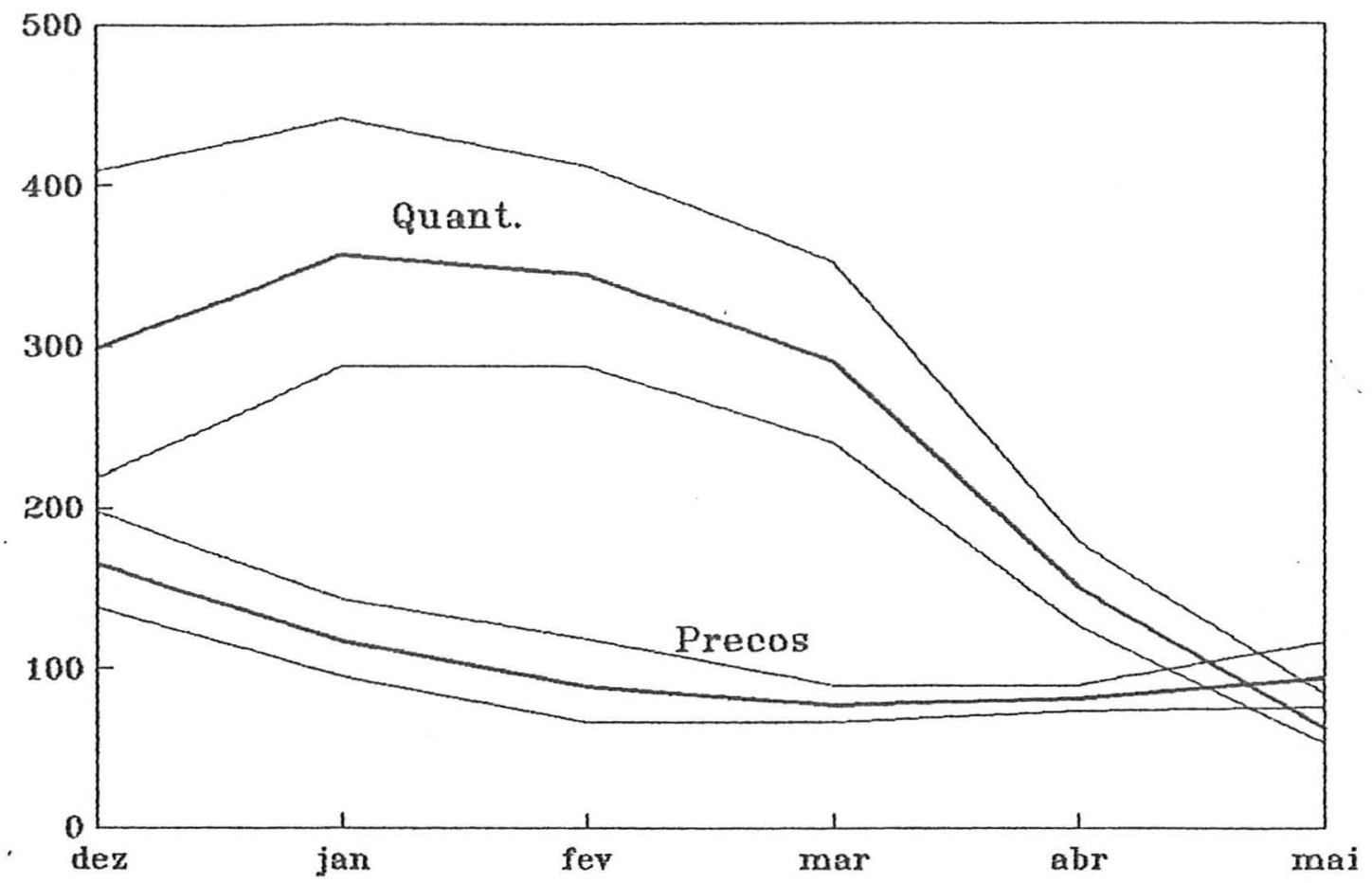

Figura 6.3 - Variacão estacional de precos deflacionados e quantidades de figo no mercado atacadista de São Paulo.

Tabela 6.3 - indices de variacăo estacional de precas deflacionados e quantidades de figo (eng - 1,80 kg) no mercado atacadista de São Paulo. Periodo de 1980-1988.

\begin{tabular}{lrrrrrr}
\hline MEsEs & \multicolumn{2}{c}{ Inferior } & \multicolumn{2}{c}{ Medio } & \multicolumn{2}{c}{ Superior } \\
& Pre6,0 & Quant. & Pre60 & Quant. & Preco & Quant. \\
\hline Dezembro & 120,87 & 218,46 & 145,26 & 298,64 & 174,67 & 408,25 \\
Janeiro & 100,25 & 287,75 & 134,04 & 356,60 & 180,66 & 441,92 \\
Fevereiro & 84,29 & 287,87 & 88,35 & 344,51 & 92,74 & 412,30 \\
Marco & 74,34 & 239,76 & 80,79 & 290,31 & 86,84 & 351,52 \\
Abril & 68,65 & 126,21 & 77,26 & 150,43 & 88,07 & 179,31 \\
Maio & 79,24 & 53,51 & 92,89 & 63,19 & 115,16 & 74,61 \\
Teste F & - & - & 18,00 & 108,26 & - & - \\
\hline
\end{tabular}




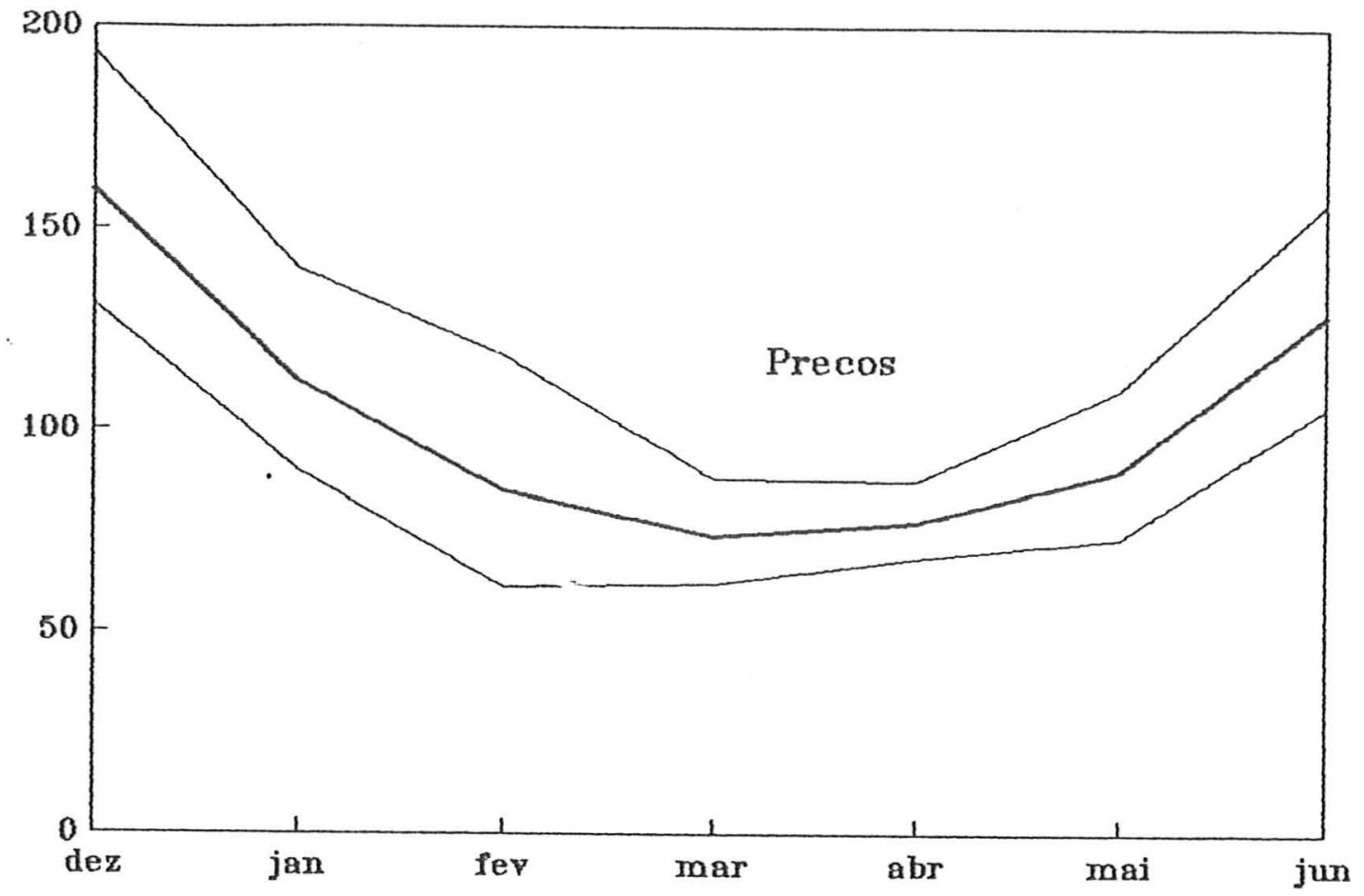

Figura 6.3.1-Variacão estacional de preços deflacionados de figo recebidos pelos produtores no Estado de São Paulo.

Tabela 6.3.1-indices de variacão estacional de prefos deflacionados de figo (eng $-3,5 \mathrm{~kg}$ ) recebidos pelos produtores no Estado de São Paulo. Periodo 1980-1988.

\begin{tabular}{lrrr}
\hline MESES & Inferior & Médio & Superior \\
\hline Dezembro & 138,28 & 165,33 & 197,68 \\
Janeiro & 95,02 & 116,59 & 143,05 \\
Fevereiro & 66,31 & 88,55 & 118,25 \\
Marco & 66,52 & 76,96 & 89,03 \\
Abril & 73,00 & 80,72 & 89,26 \\
Maio & 75,89 & 94,27 & 117,10 \\
Teste F & - & 16,65 & - \\
\hline
\end{tabular}




\subsection{Maçã Nacional}

A macieira pertence à familia das Moraceae, gênero Malus, sendo originaria da Europa e América do Norte. Apenas uma espécie produz frutos comerciais.

Em São Paulo, nas tradicionais regiões produtoras de frutos de clima temperado a macieira é explorada em pequenas propriedades, com métodos de cultivo pouco mecanizados. A despeito dos bons resultados obtidos por alguns fruticultores, a mą̧ã sofre a concorrência de culturas de exploracão mais intensa $e$ de maior rendimento por unidade de área.

No periodo de janeiro a marco os precos são ligeiramente decrescentes e a partir deste último, são crescentes.

A entrada da maçã paulista começa no mês de janeiro quando năo existe mąã no mercado, conseguindo boa cotacăo no mercado, a despeito de sua qualidade regular. A maçã da região sul começa a entrar no mercado apenas em marco e a máã estrangeira chega no mercado apenas em julho e compõe $53 \%$ do volume comercializado neste mercado.

No mês de janeiro os indices de preco da mą̃̃ nacional, predominantemente a paulista, são mais elevados que os meses subsequentes em razão da reduzida quantidade ofertada e caem até marco, que é o mês de maior entrada do 
produto, pois além da safra paulista comeca a entrada da safra sulina.

A partir do mês de abril os prequs são crescentes em virtude da escassez de frutas não frigorificadas e pela própria queda da quantidade ofertada de macã.

o último mês de oferta é o que apresenta o maior indice sazonal (IS $=126,93$ ) ao mesmo tempo em que é - mês de menor oferta (IS $=38,63$ ).

No mercado atacadista as variacões estacionais de precos não são significativas ( $F=2,21), \quad 0$ que indica precos estáveis ao longo do ano.

As quantidades sofrem maiores variacões $(F=8,06)$ em relação aos preços.

A maça possui periodo de oferta bastante extenso em funcão do desenvolvimento de cultivares precoces como Rainha, Ana, Gala e Dhio Beauty, que se adaptam a invernos menos rigorosos.

0 comportamento dos precos da macã recebidos pelos produtores paulistas não difere muito do comportamento dos preqos observados no atacado para os meses comuns. No atacado o padrão inclui os frutos originários de outras regiões (Figuras 6.4.1 e 6.4.1.).

0 componente estacional é pouco relevante na variacão de precos ao produtor $(F=3,64)$ mas ligeiramente superior ao teste observado no atacado $(F=2,21)$. 


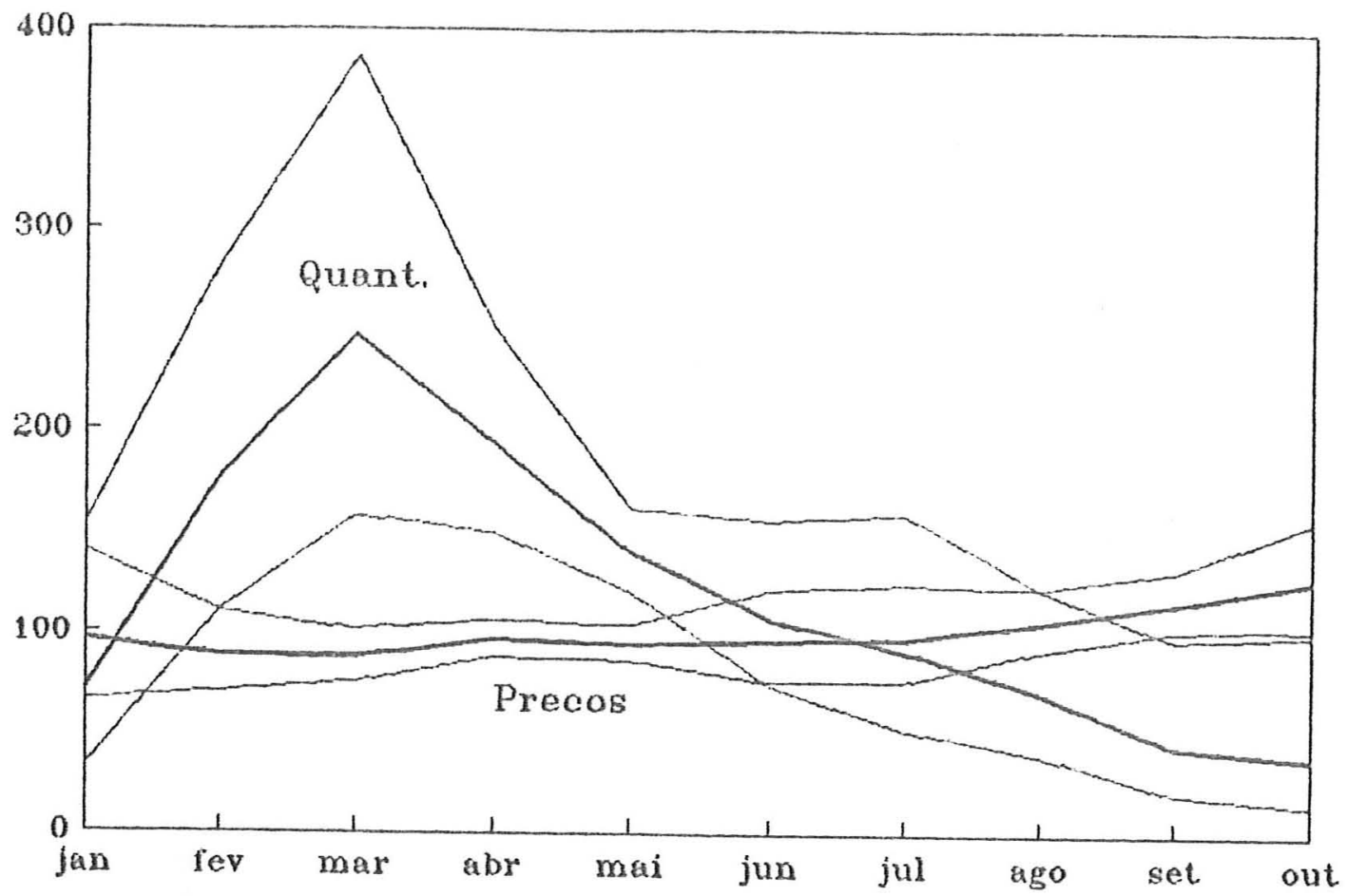

Figura 6.4 - Variacão estacional de precos deflacionados e quantidades de maçã nacional no mercado atacadista de São Paulo.

Tabela 6.4 - indices de variacão estacional de precos deflacionados e quantidades de macã nacional (cx - $21,00 \mathrm{~kg})$ no mercado atacadista de São Paulo. Periodo 1980-1988.

\begin{tabular}{lrrrrrr}
\hline MESES & \multicolumn{2}{c}{ Inferior } & \multicolumn{2}{c}{ Médio } & \multicolumn{2}{c}{ Superior } \\
& Preco & Quant. & Preco & Quant. & Preco & Quant. \\
\hline Janeiro & 66,65 & 33,40 & 96,85 & 71,67 & 140,75 & 153,79 \\
Fevereiro & 70,40 & 111,15 & 88,21 & 177,35 & 110,54 & 282,97 \\
Marco & 75,10 & 158,09 & 87,54 & 247,04 & 102,05 & 386,02 \\
Abril & 87,50 & 149,23 & 96,67 & 193,40 & 106,74 & 250,63 \\
Maio & 85,93 & 120,57 & 94,70 & 139,81 & 104,35 & 162,11 \\
Junho & 75,99 & 73,52 & 96,20 & 107,20 & 121,79 & 156,32 \\
Julho & 75,93 & 52,04 & 97,25 & 91,27 & 124,55 & 160,08 \\
Agosto & 92,06 & 40,09 & 106,35 & 70,07 & 122,85 & 122,46 \\
Setembro & 101,65 & 20,34 & 115,68 & 44,45 & 131,64 & 97,12 \\
Dutubro & 103,26 & 14,87 & 126,93 & 38,63 & 156,02 & 100,32 \\
Teste F & - & - & 2,21 & 8,06 & - & - \\
\end{tabular}




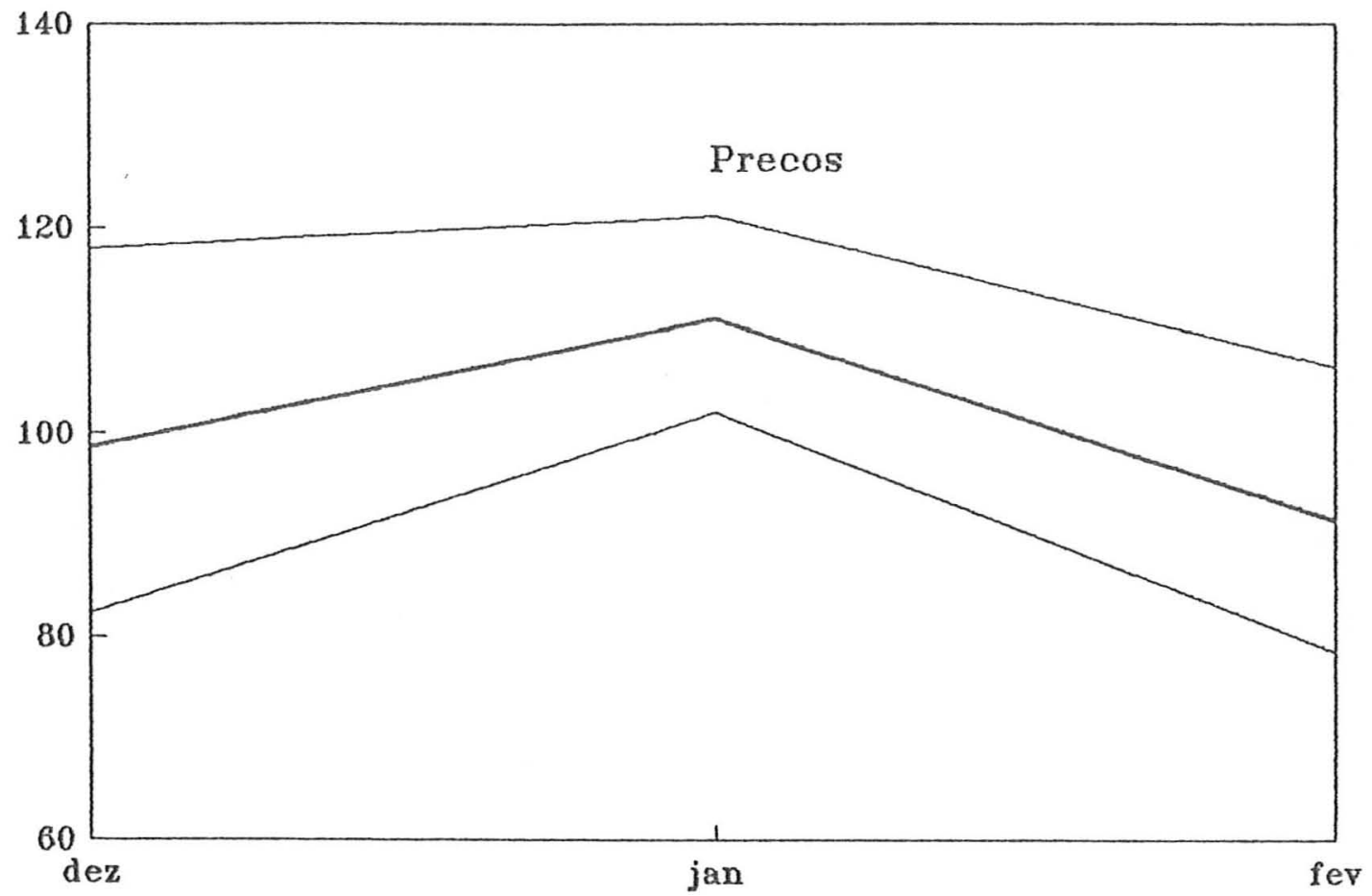

Figura 6.4.1-Variacão estacional de precos deflacionados de maç̃ recebidos pelos produtores no Estado de São Paulo.

Tabela 6.4.1-indices de variacão estacional de precos deflacionados de macã (cx- $40,00 \mathrm{~kg})$ recebidos pelos produtores no Estado de São Paulo. Periodo 1980-1.988.

\begin{tabular}{lrrr}
\hline MESES & Inferior & Médio & Superior \\
\hline Dezembro & 82,36 & 98,59 & 118,02 \\
Janeiro & 101,95 & 111,10 & 121,07 \\
Fevereiro & 78,40 & 91,29 & 106,31 \\
Testef & - & 3,64 & - \\
\hline
\end{tabular}


6.5. Manga

A manga pertence à família das Anacardeaceas e é bastante disseminada pelo Estado de São Paulo, mas são poucas os pomares explorados comercialmente. A área destinada aos pomares comerciais está crescendo dada a alta cotaçัo que o fruto atinge principalmente no mercado externo.

Ds principais municipios produtores são Jardinópolis $(17.600 t)$, Taguaritinga (4.390 t) e Fernando Prestes (4.290 t). Estes municipios totalizam $20 \%$ da producão do Estado.

A Figura 6.5 e a Tabela 6.5 mostram que no inicio da safra os precos são elevados (IS $=143,58$ ) e depois decrescentes até fevereiro $(I S=75,70)$.

Os indices de precos da manga apresentam um componente estacional relativamente elevado $(F=10,58)$, a0 passo que a estacionalidade da producão é mais acentuada $(F=59,15)$.

0 comportamento dos indices de quantidade são crescentes até dezembro, quando atingem seu nivel máximo (IS $=305,21)$ e a partir deste mês são decrescentes até o final da safra em fevereiro (IS $=44,21)$. 
A época de maturação da manga no estado de São Paulo é outubro e marco, com algumas variacões por região, de modo que o malor volume comercializado concentra-se nos meses de outubro a janeiro. Nestes meses verifica-se uma ligeira queda de precos, ocaionado pela grande quantidade ofertada que entra no mercado; além de ser uma época onde se verifica uma grande entrada de frutas no mercado atacadista. 


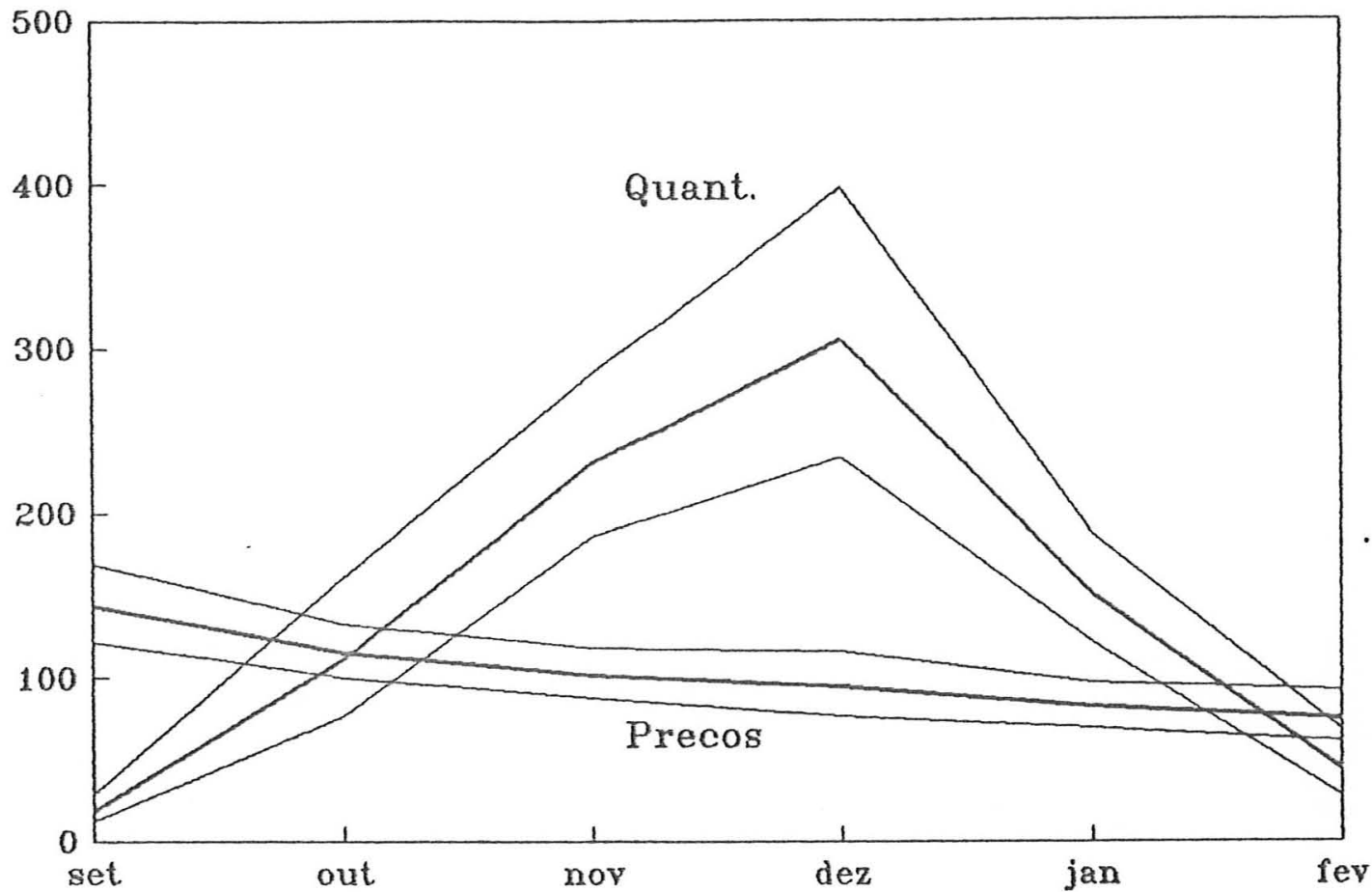

Figura 6.5 - Variacão estacional de precos deflacionados e quantidades de manga no mercado atacadista de São Paulo

Tabela 6.5 - Indices de variacão estacional de precos reais e quantidades de manga (crm - $25,00 \mathrm{~kg}$ ) no mercado atacadista de São Paulo. Periodo 19801988

\begin{tabular}{lrrrrrr}
\hline MESES & \multicolumn{2}{c}{ Inferior } & \multicolumn{2}{c}{ Médio } & \multicolumn{2}{c}{ Superior } \\
& Preco & Quant. & Preco & Quant. & Preco & Quant. \\
\hline Setembro & 121,43 & 12,39 & 143,58 & 19,06 & 169,76 & 29,33 \\
Dutubro & 100,23 & 76,91 & 115,37 & 111,35 & 132,79 & 161,22 \\
Novembro & 87,58 & 186,24 & 101,85 & 230,30 & 118,43 & 284,78 \\
Dezembro & 76,93 & 233,90 & 94,65 & 305,21 & 116,46 & 398,25 \\
Janeiro & 70,18 & 122,24 & 82,71 & 151,54 & 97,46 & 187,86 \\
Fevereiro & 61,68 & 28,61 & 75,70 & 44,21 & 92,90 & 68,31 \\
Teste F & - & - & 10,58 & 59,15 & - & -
\end{tabular}


6.6. Mexerica

As mekericas pertencem ao gênero citrus, espécie citrus reticulata. São plantas resistentes ao frio e são ofertadas nas épocas mais frias. É uma planta de producão bastante regionalizada, concentrada na Baikada do Ribeira, onde os municipios de Pariqueracu (10.404 t) e Registro (6.120 t) responderam por $35 \%$ da producão do Estado no ano de 1989. Dutros municipios importantes são Mogi Guacu e Capela do Alto.

Os indices de precos da mexerica são decrescentes até junho, quando atingem o ponto mais baiko $(I S=78,19)$, recuperam-se até o mês de agosto $(119,69)$ e mantém-se estáveis até a final da safra, em setembro.

0 componente estacional dos precos de mexerica é inferior $(F=6,03)$ aos indices de quantidade $(F=11,85)$.

Observa-se pela Figura 6.6 e Tabela 6.6 que os indices de precos e indices de quantidade movem-se em direcões contrárias, indicando que o preco é bastante influenciado pela quantidade ofertada. 


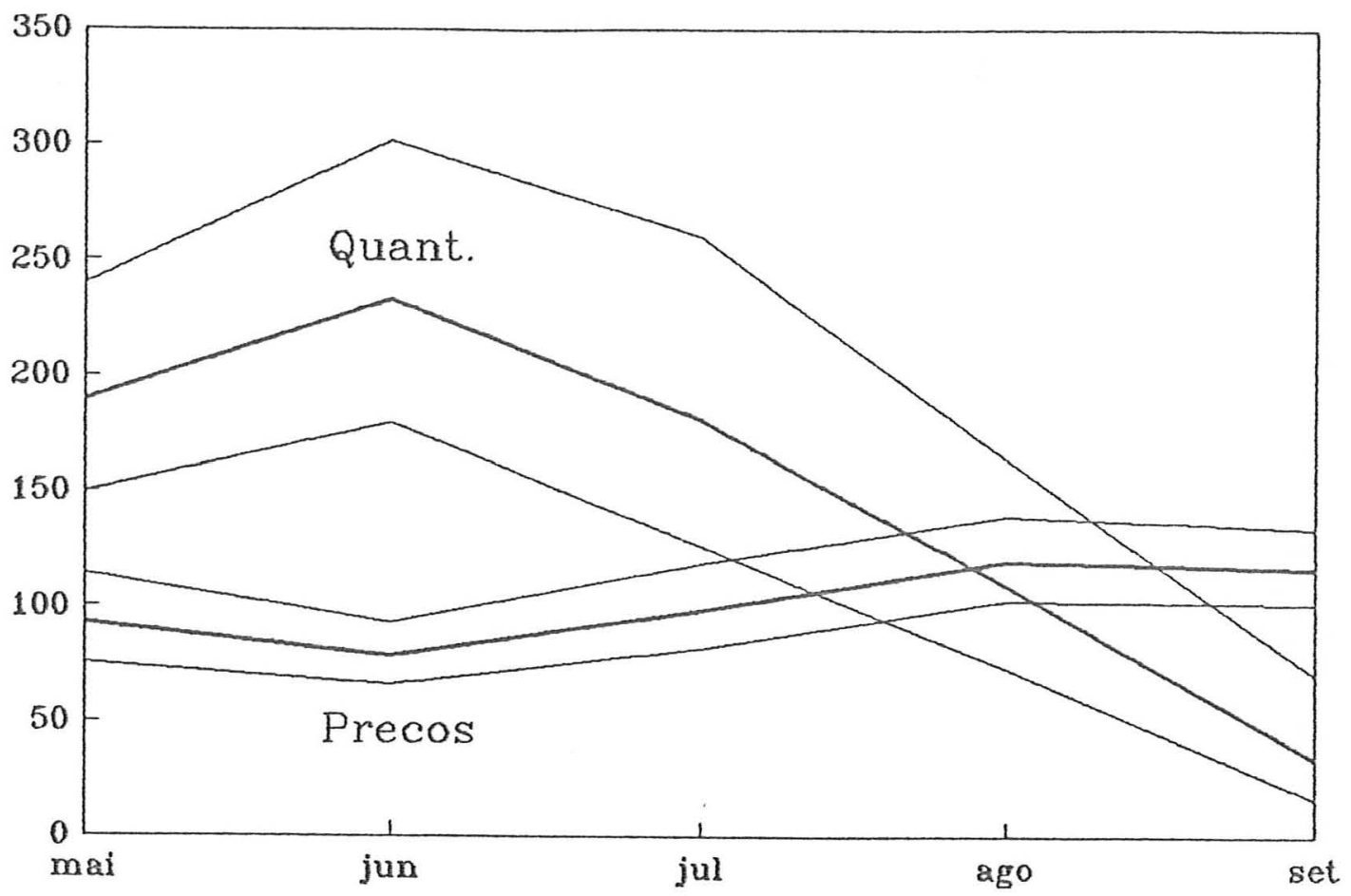

Figura ó.ó - Variacão estacional de precos deflacionados e quantidades de mexerica no mercado atacadista de São Paulo

Tabela 6.6 - indices de variacão estacional de precos deflacionados e quantidades de mexerica (cxm $27,00 \mathrm{~kg})$ no mercado atacadista de São Paulo. Periodo 1980-1.988.

\begin{tabular}{lcccccc}
\hline MESES & \multicolumn{2}{c}{ Inferior } & \multicolumn{2}{c}{ Médio } & \multicolumn{2}{c}{ Superior } \\
& Preco & Quant. & Preco & Quant & Preco & Quant. \\
\hline Maio & 75,77 & 149,49 & 93,13 & 189,29 & 114,46 & 239,69 \\
Junho & 65,75 & 179,33 & 78,19 & 232,60 & 92,99 & 301,69 \\
Julho & 81,91 & 126,19 & 98,47 & 181,15 & 118,38 & 260,04 \\
Agosto & 102,62 & 73,15 & 119,69 & 109,53 & 139,60 & 164,01 \\
Setembro & 101,12 & 16,65 & 116,52 & 34,15 & 134,27 & 70,03 \\
Teste F & - & - & 6,03 & 11,85 & - & - \\
\hline
\end{tabular}




\subsection{Morango}

- morango é uma cultura que necessita de grandes despesas de custeio, mas que tem alto retorno devido aos precos alcancados no mercado. Além disso apresenta a vantagem de poder dirigir os frutos de pior qualidade do final da safra à industria, que busca o produto na propriedade.

A principal procedência do morango comercializado no mercado atacadista é a microrregião de Braganca Paulista. Os principais municipios produtores são Atibaia $(9.600 \mathrm{t})$, Cabreúva $(4.320 \mathrm{t})$, Jundiai e Piedade (2. 400 t cada), na safra de 1989 .

A entrada do morango no mercado ocorre a partir do mês de maio, que é uma época de pouca oferta de frutas e por isso alcanca altas cotacões (indice Sazonal = 175,66). A partir de então a oferta comeca a aumentar depreciando os prefos.

A segunda florada em meados de julto, com uma grande producão de frutos de boa qualidade está relacionado com o pico da comercializacăo em agosto e consequente pico de queda de precos.

A partir de agosto, a entrada de outras frutas no mercado e a baika qualidade dos frutos da terceira florada contribuem para que os precos não se 
elevem anda que a quantidade ofertada tenha se reduzido significativamente em reląão ao pico da safra, como mostra a Figura 6.7 e a Tabela 6.7.

A Tabela 6.7 mostra que o componente estacional dos precos $(F=25,90)$ é inferior ao componente estacional das quantidades $(F=150,09)$.

o comportamento dos precos de morango ao nivel do produtor e ao nivel atacadista são bastante semelhantes (Figuras 6.7 e 6.14 ).

As principais causas do comportamento dos precos é a quantidade ofertada e a qualidade dos frutos.

o componente estacional é semelhante para os precos a nivel do produtor $(F=23,51)$ em relacão à variąão de precos no atacado ( $F=25,90$ ). 


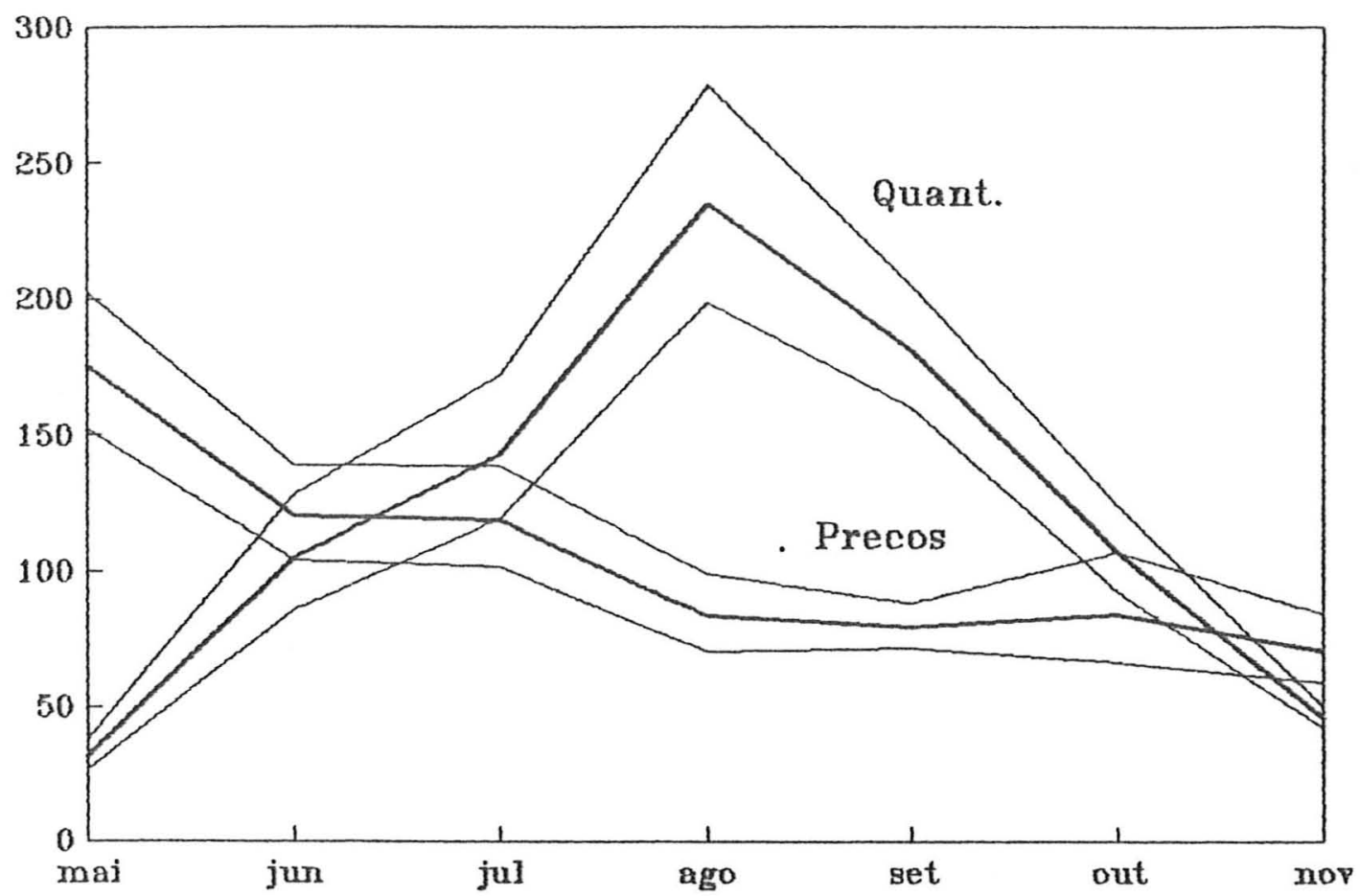

Figura 6.7 - Variacão estacional de preços deflacionados e quantidades de morango no mercado atacadista de São Paulo.

Tabela 6.7 - indices de variacão estacional de precos deflacionados e quantidades de morango (ckt $3,20 \mathrm{~kg})$ no mercado atacadista de São Paulo. Período 1980-1988.

\begin{tabular}{lrrrrrr}
\hline MESES & \multicolumn{2}{c}{ Inferior } & \multicolumn{2}{c}{ Médio } & \multicolumn{2}{c}{ Superior } \\
& Preco & Quant. & Preco & Quant & Preco & Quant. \\
\hline Maio & 152,99 & 26,60 & 175,66 & 31,64 & 202,94 & 37,63 \\
Junho & 104,36 & 85,79 & 120,36 & 104,94 & 138,79 & 128,37 \\
Julho & 101,57 & 118,91 & 118,66 & 142,91 & 138,67 & 171,75 \\
Agosto & 70,64 & 198,67 & 83,63 & 235,18 & 99,28 & 278,11 \\
Setembro & 71,73 & 166,26 & 79,57 & 181,18 & 88,54 & 204,83 \\
Outubro & 66,78 & 92,43 & 84,29 & 107,13 & 107,38 & 124,17 \\
Novembro & 59,13 & 42,55 & 71,03 & 46,15 & 84,15 & 50,50 \\
Teste F & - & - & 25,90 & 150,09 & - & - \\
\hline
\end{tabular}




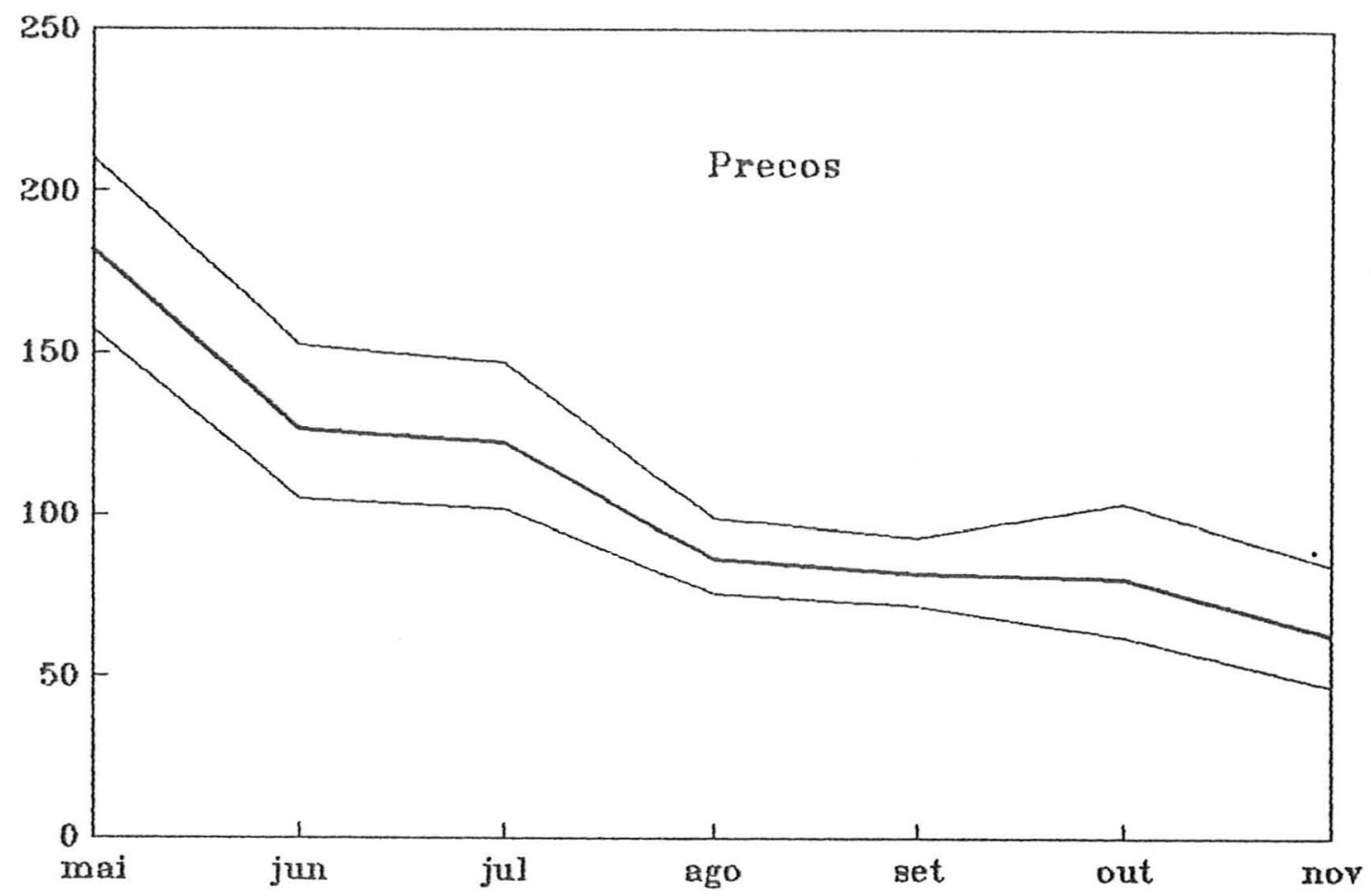

Figura 6.7.1-Variacão estacional de precos deflacionados de morango recebidos pelos produtores no Estado de São Paulo.

Tabela 6.7.1-indices de variacão estacional de precos deflacionados de morango ( $\mathrm{Ck}-4,00 \mathrm{~kg})$ recebidos pelos produtores no Estado de São Paulo. Periodo 1980-1988.

\begin{tabular}{lccr}
\hline MESES & Inferior & Médio & Superior \\
\hline Maio & 157,82 & 183,47 & 214,65 \\
Junho & 104,39 & 127,30 & 155,25 \\
Julho & 101,75 & 122,79 & 148,17 \\
Agosto & 75,70 & 86,72 & 99,10 \\
Setembro & 71,81 & 81,78 & 93,14 \\
Outubro & 62,26 & 80,25 & 103,45 \\
Novembro & 46,96 & 62,89 & 84,23 \\
Teste F & - & 23,51 & - \\
\hline
\end{tabular}




\section{8. Nectarina}

A nectarina é da mesma espécie das pêssegos, cuja variedade nucipersica produz frutos desprovidos de pilosidade

Esta cultura tem crescido em funcão do aumento da demanda. 0 volume de comercializáão, entretanto, é reduzjdo quando comparado com os pêssegos. Além disso, parte da demanda é atendida pelos frutos de origem estrangeira.

o melhoramento tem se desenvolvido no sentido de aumentar o periodo de oferta até janeiro. Normalmente a colheita termina em dezembro.

As principais regiões produtoras localizam--se nos municipios de Marilia (954 t) e Mairinque (315 t)

A Tabela 6.8 e a Figura 6.8 mostram que os indices estacionais de precos são mais elevados no inicio e no final da safra quando at ingem indices sazonais iguais a 129,57 e 107,84 , respectivamente. O menor indice de preco se verifica no mês de outubro (IS $=82,32$ ).

A importancia da estacionalidade nos precos $(F=4,06)$ é bastante inferior à da quantidade $\langle F=68,44\rangle$. A oferta de nectarina comera no mês de setembro e aumenta até outubro, que é o pico da comercialização $(F=273,24)$. A partir deste mês os indices 
de quantidade são crescentes até dezembro que é o mês final da safra.

$$
\text { Pode-se observar que os indices de precos são }
$$
bastante influenciados pela quantidade ofertada 


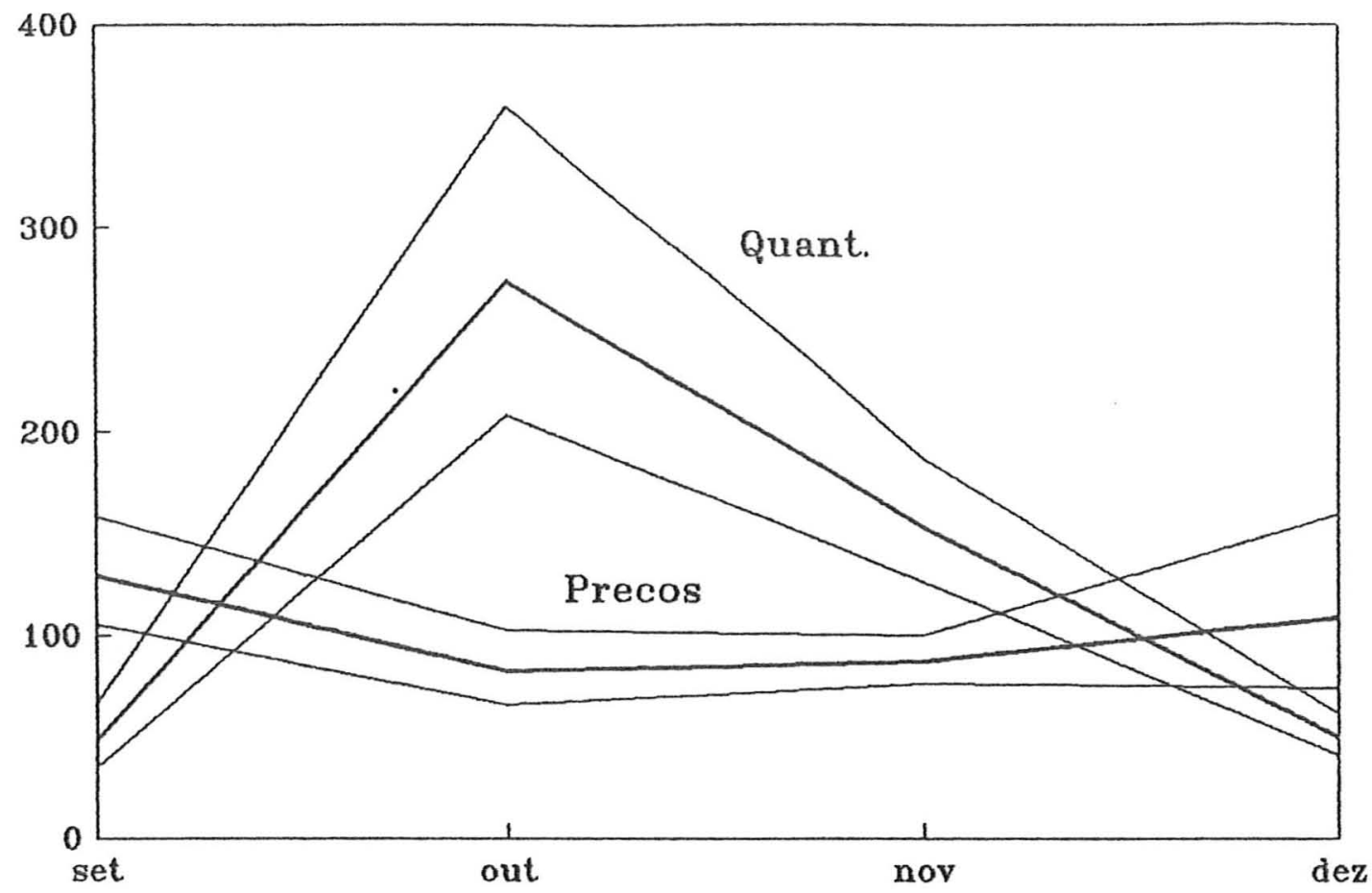

Figura 6.8 - Variąão estacional de precos deflacionados e quantidades de nectarina no mercado atacadista de São Paulo

Tabela 6.8 - indices de variacão estacional de preços deflacionados e quantidades de nectarina (cxt 2, $25 \mathrm{~kg})$ no mercado atacadista de São Paulo. Período $1980-1988$

\begin{tabular}{lrrrrrr}
\hline MESES & \multicolumn{2}{c}{ Inferior } & \multicolumn{2}{c}{ Médio } & \multicolumn{2}{c}{ Superior } \\
& Preco & Quant. & Preco & Quant. & Preco & Quant. \\
\hline Setembro & 105,68 & 34,96 & 129,57 & 48,27 & 158,87 & 66,66 \\
Dutubro & 66,09 & 207,86 & 82,32 & 273,24 & 102,55 & 359,20 \\
Novembro & 75,93 & 126,00 & 86,94 & 153,40 & 99,54 & 186,75 \\
Dezembro & 73,35 & 40,26 & 107,84 & 49,41 & 158,53 & 60,64 \\
Teste F & - & - & 4,06 & 68,44 & - & - \\
\hline
\end{tabular}


6.9. Nespera

A nêspera Eriobotrya japonica é uma fruta de origem japonesa, cuja exploração no Estado de São Paulo vem aumentando, pois sua maturacão ocorre nos meses de maio a novembro, época de escassez de frutas no mercado. Ainda assim tem baixissima expressão no mercado onde participa com menos de $0,01 \%$ do valor comercializado no setor atacadista de frutas.

Assim como outras frutas cuja colheita se dá no inverno, é uma excelente opqão para o aproveitamento dos fatores de producão ociosos nesta época do ano nas propriedades fruticolas.

Uma desvantagem do cultivo da nespereira que limita sua expansão é a alta exigência em mão-de-obra, com relaço à principal cultura concorrente que é a ameika (PENTEADO, 1986).

No Estado de São Paulo, a principal região produtora se encontra nos municipios de Mogi das Cruzes $(1800 t)$ e Pilares $(660 t)$, que correspondeu a $80 \%$ da producão do estado na safra de 1989.

A Tabela 6.9 e a Figura 6.9 mostram que os preços da nêspera são decrescentes a partir de julho, que é o mês onde se verifica o maior indice (IS $=126,90$ ). 
As quantidades são crescentes até o mês de setembro, que é o mês de mãior oferta (IS $=314,04$ ) e caem no mês de outubro para $1.85,62$.

Existe reląăa entre os precos e a quantidade ofertada, pois o pico da comercializacăo coincide com uma queda dos precos em setembro. 


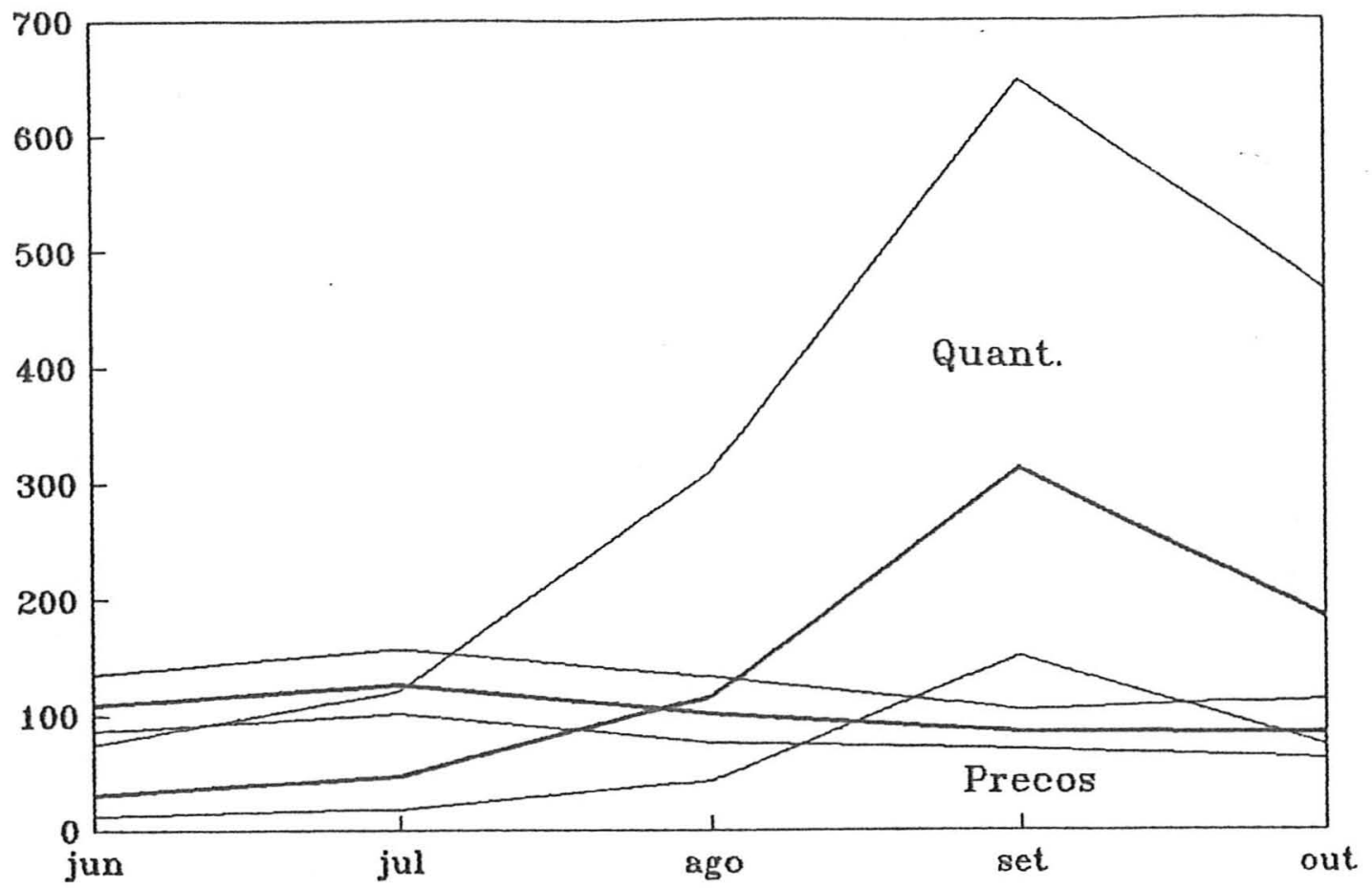

Figura 6.9 - Variacão estacional de precos deflacionados e quantidades de nêspera no mercado at acadista de São Paulo.

Tabela 6.9 - indices de variacăo estacional de precos deflacionados e quantidades de nêspera (cxt $5,00 \mathrm{~kg})$ no mercado atacadista de São Paulo. Periodo $1980-1988$

\begin{tabular}{lrrrrrr} 
MESES & \multicolumn{2}{c}{ Inferior } & \multicolumn{2}{c}{ Médio } & \multicolumn{2}{c}{ Superjor } \\
& Preco & Quant. & Preco & Quant. & Preco & Quant. \\
\hline Junho & 86,19 & 12,91 & 108,12 & 30,98 & 135,64 & 74,33 \\
Julho & 102,06 & 18,76 & 126,90 & 47,57 & 157,79 & 120,59 \\
Agosto & 76,85 & 43,59 & 101,30 & 116,36 & 133,53 & 310,64 \\
Setembro & 70,37 & 152,29 & 85,70 & 314,04 & 104,38 & 647,57 \\
Outubro & 62,35 & 73,75 & 83,95 & 185,62 & 113,02 & 467,16 \\
Teste F & - & - & 2,88 & 6,82 & - & -
\end{tabular}




\subsection{Pera}

A pera Pirus vulgaris é uma fruta tipica de climas temperados e tem sido cultivada no Brasil desde o inicio do século. Nas décadas de 50 e 60 , a pera era cultivada em regiões mais frias, como os municipios de São Roque, Itu e Atibaia (PENTEADO, 1986). Após este periodo é patente a reducão da área cultivada, sendo que grande parte da demanda é atendida pelo fruto importado.

Hoje as principais regiões produtoras localizam-se nos municipios de Pilar do Sul (765 t) e Campos do Jordão (4e5 $t$ ). Esta quantidade produzida é inferior $\dot{a}$ da maçã, por exemplo, que é a cultura concorrente. A produção total de peras no estado foi de 2.924 t e a de macãs foi de 8.600 t. Estes numeros referem-se à safra de 1989.

o comportamento dos precos é decrescente (IS= $=123,42 \mathrm{em}$ janeiro, e IS $=75,65 \mathrm{em}$ marcol em funcão da elevada entrada de pera estrangeira no mercado que se dá em fevereiro. A queda de cotacão se dá porque a qualidade do fruto nacional é inferior à do fruto estrangeiro, originário principalmente da Argentina (Figura 6.10 e Tabela 6.10).

Dadas estas condicões, o melhoramento deve ser no sentido de introduzir variedades precoces, pouco exigentes em frio e tão tenras quanto as frutas estrangeiras. 
Neste sentido a pesquisa genéticá já introduziu algumas variedades com estas caracteristicas como Seleta, Triunfo e Tenra, que já têm pomares formados 


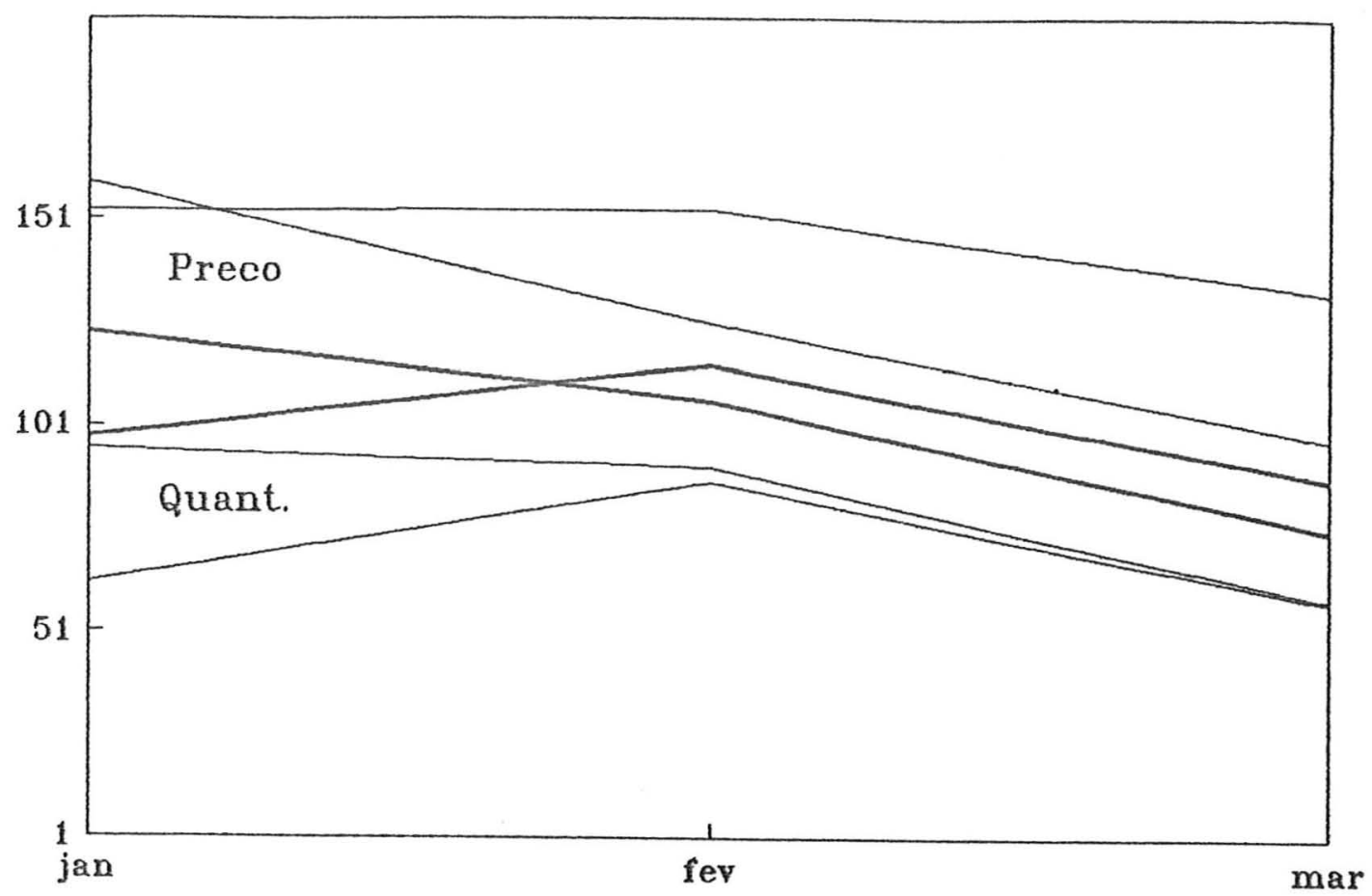

Figura 6.10-Variacão estacional de precos deflacionados e quantidades de pera nacional no mercado atacadista de São Paulo.

Tabela b.10-indices de variacão estacional de precos deflacionados de pera nacional (cx-17,00 kg) no mercado atacadista de São Paulo. Periodo $1980-1988$

\begin{tabular}{lcrrrrr} 
MESES & \multicolumn{2}{c}{ Inferior } & \multicolumn{2}{c}{ Médio } & \multicolumn{2}{c}{ Superior } \\
& Preco & Quant. & Preco & Quant. & Preco & Quant. \\
\hline Janeiro & 95,26 & 62,81 & 123,42 & 98,09 & 159,91 & 153,18 \\
Fevereiro & 91,05 & 87,47 & 107,10 & 115,86 & 125,96 & 153,45 \\
Marfo & 58,64 & 58,11 & 75,65 & 87,98 & 97,61 & 133,26 \\
Teste F & - & - & 6,29 & 0,86 & - & -
\end{tabular}




\subsection{Péssego}

0 pêssego pertence à familia das Rosáceas, género Prumus, sendo que a espécie $F$. persica produz frutos comerciais.

A producão de pêssegos concentra-se principalmente nos municipios de Guapiara e Mogi das Cruzes que totalizaram $41 \%$ da producão do estado na $5 a f r a$ de 1989.

Os indices de preços são mais elevados nos meses de novembro, dezembro quando atingem indices de $105,27,120,92$, respectivamente (Tabela 6.11). Os menores indices de precos podem ser observados principalmente no final da safra (IS $=97,34$ ).

o componente estacional dos precas tem menor importância nos preços $(F=6,30)$ que nas quantidades $(F=70,70)$.

As quantidades têm comportamento semelhantes aos prefos, ou seja, os picos de comercializacão verificam-se nos meses de novembro, dezembro e janeiro com indices de $220,81,270,92$ e 129,30 , respectivamente.

Os padrões de variagão de preços do produtor difere daquele observado no mercado atacadista nos meses de outubro e novembro (Figuras 6.11 e 6.15) e são mais estáveis ao nivel do produtor $(F=0,44)$. 


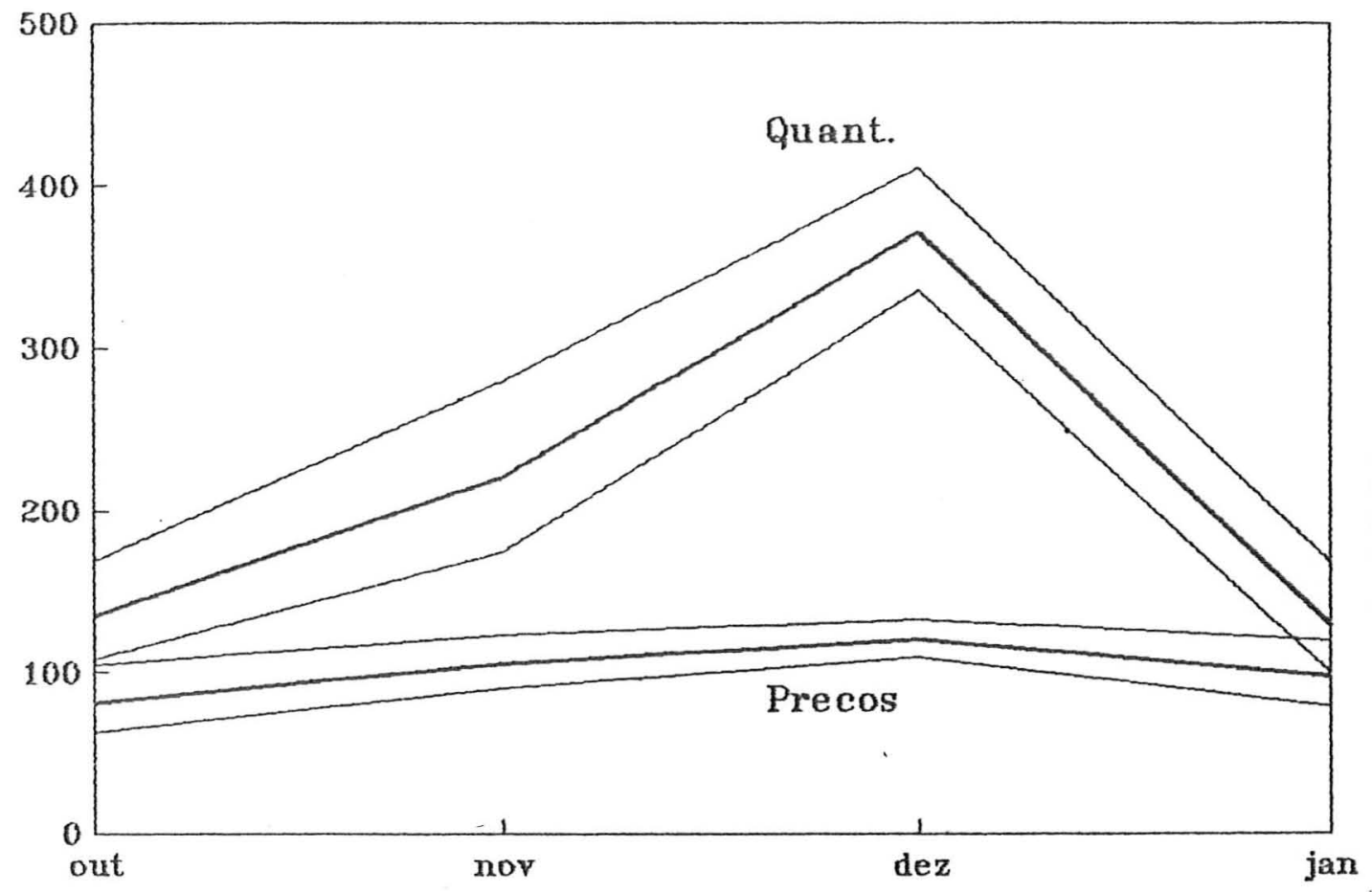

Figura 6.11- Variaçăo estacional de precos deflacionados e quantidades de pêssego no mercado atacadista de São Paulo.

Tabela 6.11-indices de variacão estacional de prefos deflacionados e quantidades de pêssego (cxt $2,34 \mathrm{~kg})$ no mercado atacadista de São Paulo. Periodo 1986-1988.

\begin{tabular}{lrrrrrr}
\hline \multirow{2}{*}{ MESES } & \multicolumn{2}{c}{ Inferior } & \multicolumn{2}{c}{ Médio } & \multicolumn{2}{c}{ Superior } \\
& Preco & Quant & Preco & Quant. & Preco & Quant. \\
\hline Outubro & 62,40 & 107,91 & 80,89 & 135,06 & 104,17 & 169,03 \\
Novembro & 90,38 & 174,57 & 105,27 & 220,81 & 122,66 & 279,28 \\
Dezembro & 109,66 & 335,26 & 120,92 & 270,92 & 132,79 & 410,37 \\
Janeiro & 79,74 & 99,66 & 97,34 & 129,30 & 119,96 & 167,36 \\
Teste F & - & - & 6,30 & 70,70 & - & - \\
\end{tabular}




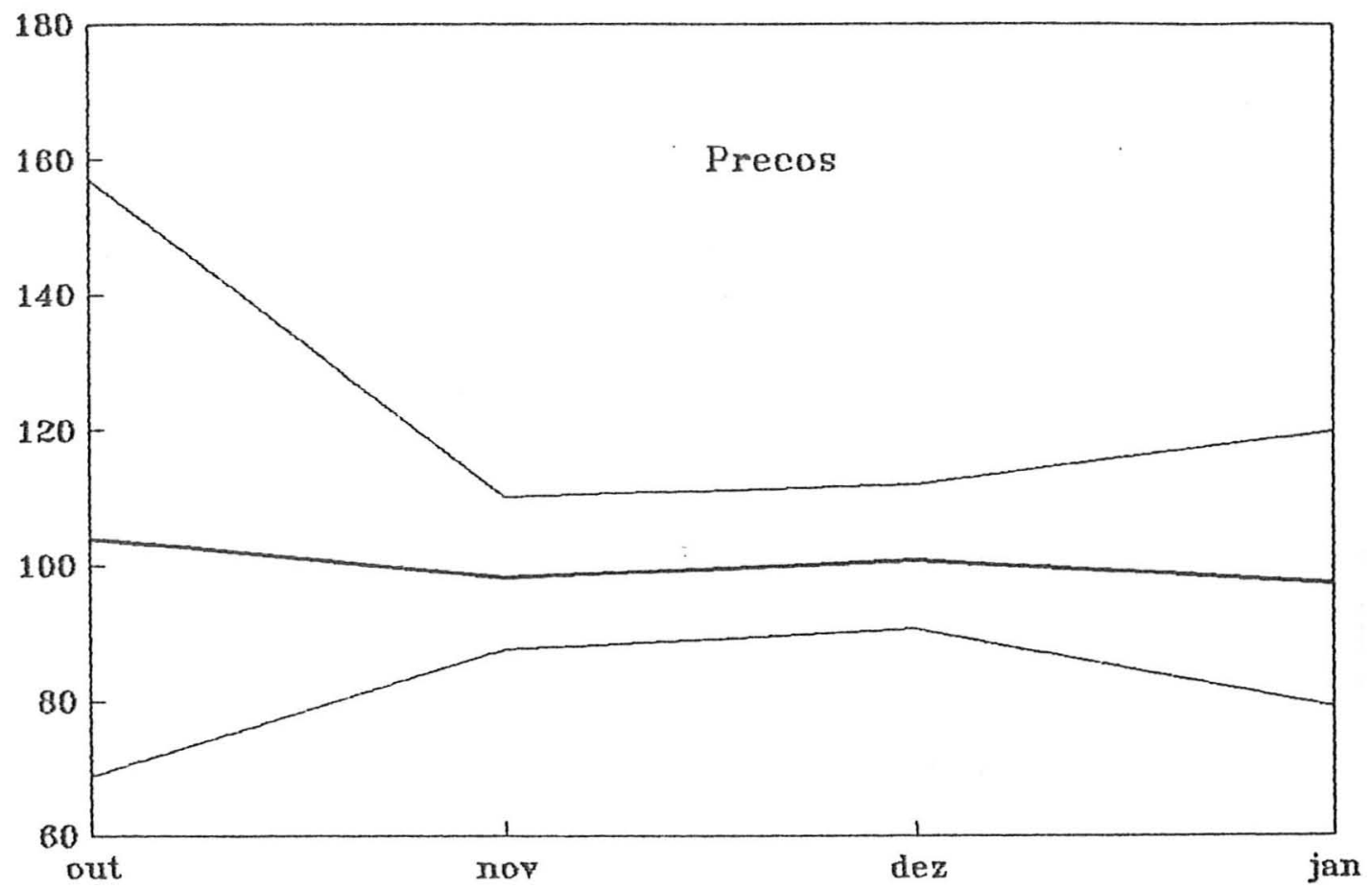

Figura 6.11.1 - Variacão estacional de precos deflacionados de pêssego recebidos pelos fruticultores no Estado de São Paulo.

Tabela 6.11.1 - indices de variacão estacional de precos deflacionados de pêssego (ckt $-2,50 \mathrm{~kg}$ ) recebidos pelos produtores no Estado de São Paulo. Período 1980-1988.

\begin{tabular}{lcrr}
\hline MESES & Inferior & Médio & Superior \\
\hline Dutubro & 68,85 & 103,96 & 186,92 \\
Novembro & 87,59 & 98,21 & 110,11 \\
Dezembro & 90,59 & 100,67 & 111,88 \\
Janeiro & 79,07 & 97,27 & 119,67 \\
Teste F & - & 0,11 & - \\
\hline
\end{tabular}




\subsection{Tangerina Poncan}

A tangerina poncan é uma fruta tipica dos meses mais frios cuja comercializacão tem inicio no mês de marco, quando atinge os maiores indices de precos (IS $=140,07)$. Os indices de precos caem até o mếs de junho $(I S=71,99)$ e se elevam até o mês de setembro, quãndo atingem o indice de 123,78 .

o comportamento da quantidade comercializada é simétrica ao comportamento dos preços. No mês de marco é observado um indice bastante reduaido (IS $=27,75$ ). 0 auge da comercialização se dá no mês de junho (IS $=326,19$ ).

Assim como as demais frutas, à quantidade comercializada apresenta estacionalidade maior $(F=55,38)$ que os prequs $(F=20,63)$.

Os maiores indices de precos ao produtor para a tangerina são verificados nos meses de marco, outubro $a$ novembro com indices de 133,58, 131,93 e 142,87, respectivamente. 0 periodo de oferta comeca no mês de marco até novembro, sendo que a estacionalidade é relativamente importante na variação de preços $(F=24,16)$ como mostrà a Tabela 6.16

Ds meses que apresentam maior irregularidade nos indices são agosto, setembro e novembro.

É importante lembrar que os prefos de tangerina ao nivel do produtor incluem os três tipos 
(murcote, cravo e poncan), não sendo, portanto, comparáveis com as precos a nivel do atacado. 


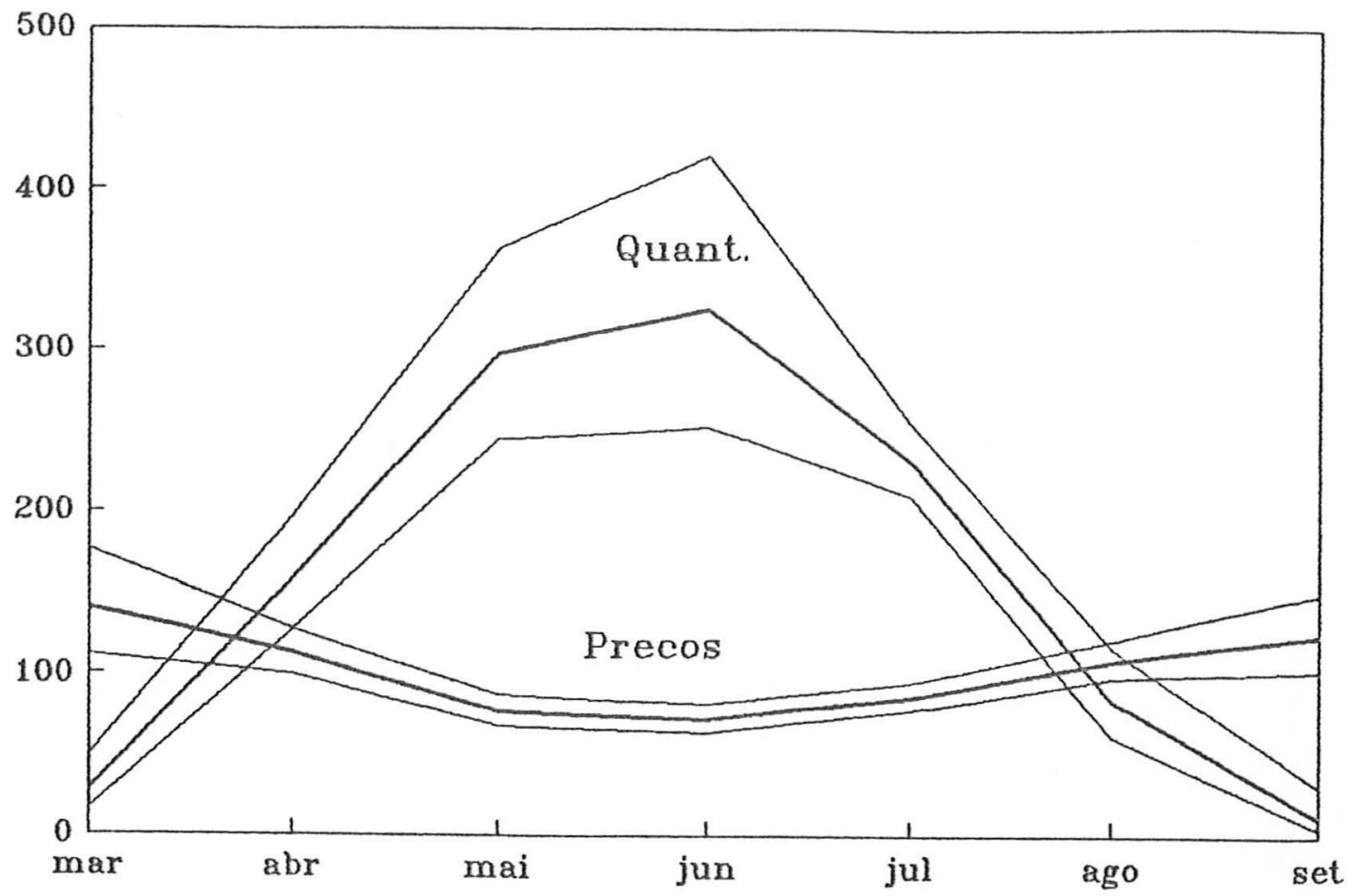

Figura 6.12-Variacão estacional de precos deflacionados e quantidades de tangerina poncan (ckm-27,00 kg) no mercado atacadista de são Paulo. Período $1980-1988$.

Tabela 6.12- indices de variăão estacional de precos deflacionados e quantidades de tangerina poncan (cxt - $27,00 \mathrm{~kg}$ ) no mercado atacadista de São Paulo. Periodo 1980-1988.

\begin{tabular}{lrrrrrr}
\hline \multirow{2}{*}{ Meses } & \multicolumn{2}{c}{ Inferior } & \multicolumn{2}{c}{ Médio } & \multicolumn{2}{c}{ Superior } \\
& Preco & Quant. & Preco & Quant & Preco & Quant. \\
\hline Marco & 111,11 & 15,74 & 140,07 & 27,75 & 176,57 & 48,93 \\
Abril & 99,65 & 126,58 & 112,48 & 157,55 & 126,95 & 196,08 \\
Maio & 67,86 & 244,46 & 76,95 & 297,77 & 87,25 & 362,71 \\
Junho & 63,34 & 252,75 & 71,99 & 326,19 & 81,83 & 420,97 \\
Julto & 77,50 & 209,80 & 85,54 & 231,41 & 94,41 & 255,25 \\
Agosto & 97,30 & 61,39 & 108,19 & 84,40 & 120,30 & 116,04 \\
Setembro & 102,42 & 4,69 & 123,78 & 12,05 & 149,60 & 30,97 \\
Teste F & - & - & 20,63 & 55,39 & - & - \\
\hline
\end{tabular}




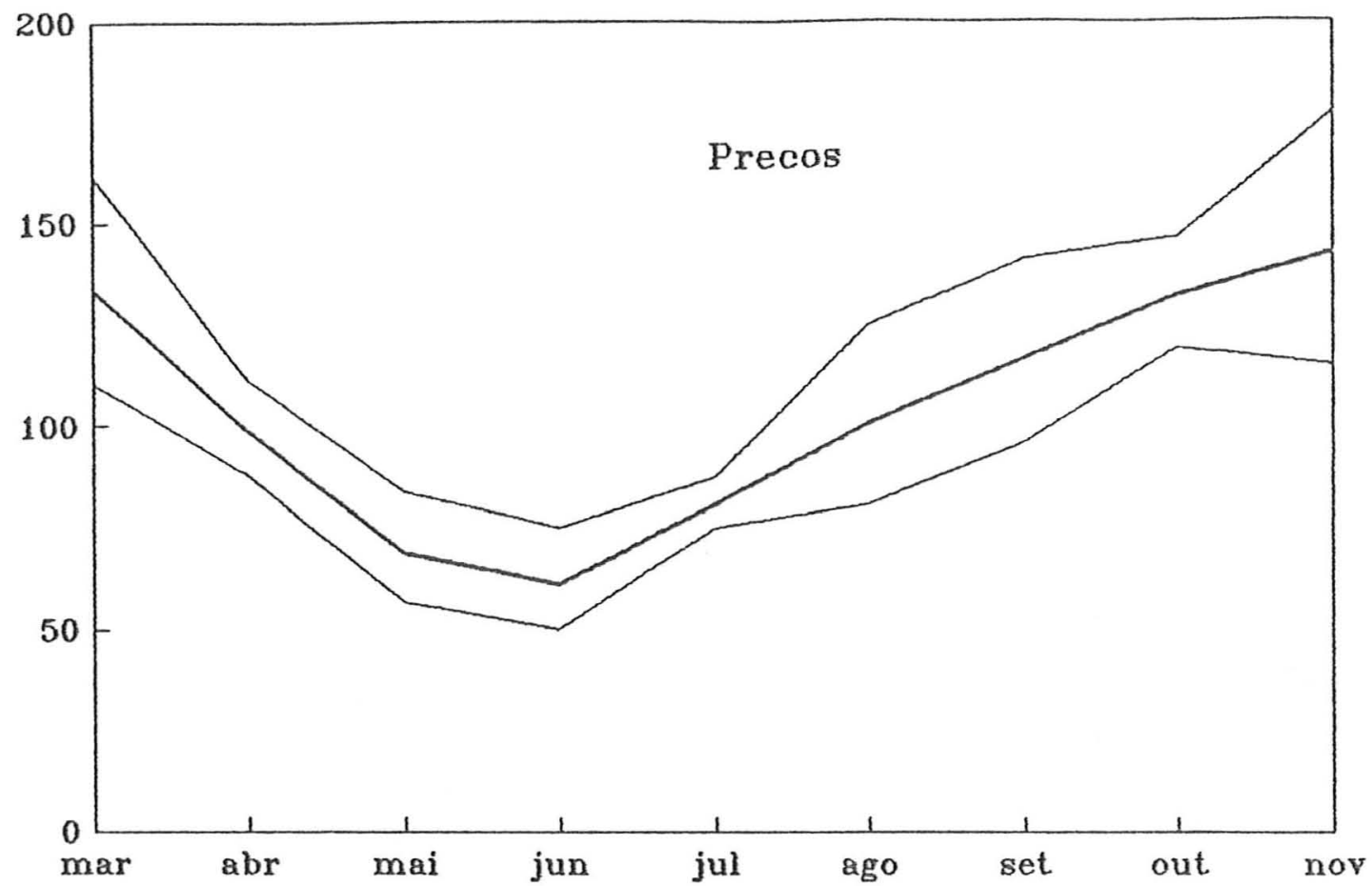

Figura ó.12.1-Variacão estacional de precos deflacionados de tangerina recebidos pelos produtares no Estado de São Paulo

Tatela 6.12.1-indices de variacão estacional de precos nominais de tangerina ( $\mathrm{cx}-40,8 \mathrm{~kg}$ ) recebidos pelas produtores no Estado de $5 \tilde{a} 0$ Faulo. Periodo 1980-1988.

\begin{tabular}{lrrr}
\hline MESES & Inferior & Médio & Superior \\
\hline Marco & 110,23 & 133,58 & 161,87 \\
Abril & 87,81 & 98,81 & 111,19 \\
Maio & 57,65 & 69,21 & 83,98 \\
Junho & 50,37 & 61,54 & 75,19 \\
Julho & 74,82 & 80,82 & 87,30 \\
Agosto & 80,72 & 100,34 & 124,71 \\
Setembro & 95,96 & 116,33 & 141,04 \\
Dutubro & 119,00 & 131,93 & 146,25 \\
Novembro & 114,99 & 142,87 & 177,50 \\
Teste F & - & 24,16 & -
\end{tabular}




\subsection{Uva Niágara ou Comum}

A culturà dà videira constitui à base da sustentacão agricola de muitas regiões, não somente como fruta fresca para mesa, mas também como matéria-prima para a producão de vinho e suco não fermentado.

No Brasil, as maiores plantacões de uva para vinho estão localizadas no Rio Grande do Sul, enquanto no Estado de São Paulo predomina o plantio de castas para mesa. Outros estados produtores de uva com expressão econômica são Minas Gerais, Paranà e Santa Catarina.

No Norte do Paraná, em Londrina, está se desenvolvendo um núcleo de producão de uvas finas. No nordeste brasileiro, de clima quente semi-árido, com emprego de irrigacão, encontra-se uma viticultura de grandes possibilidades futuras, principalmente nos municipios de Petrolândia e Floresta.

A producão paulista de uvas finas baseia-se na cultivar "Itália". As principais regiões produtoras encontram-se nos municipios de São Miguel Arcanjo (18.900 t) e Pilar do Sul $(7.000$ t). A producão total do estado atingiu no ano de 1989 o total de 31.500 t

Entretanto, a viticulturà de maior expressão no estado continua sendo a producão de uvas rústicas para mesa, predominando as variedades americanas, cuja principal representante é a "Niágara Rosada". No estado, a região de 
Jundiai-Louveira mantém a lideranca na producão desta uva em cerca de 1.100 propriedades com área inferior a 10 ha (0JIMA, 1984).

0 municipio de Jundiai produziu na safra de $198918.000 \mathrm{t}$, seguido dos municipios de São Miguel Arcanjo e Indaiatuba, com $5.000 t$ e $9.500 t$, respectivamente.

Ds maiores indices de precos no mercado atacadista foram observados no inicio da safra atingindo o IS $=183,63$, ao mesmo tempo em que se observam os menores indices de quantidade comercializada ( IS $=14,23$ ). $A$ comercialização de frutas atinge o auge no mês de dezembro com maior volume comercializado ( IS $=371,83$ ), e os precos mais reduzidos foram observados no mês de fevereiro, onde $I S=70,63$.

Também para esta fruta, a estacionalidade de precos é inferior à da quantidade. 


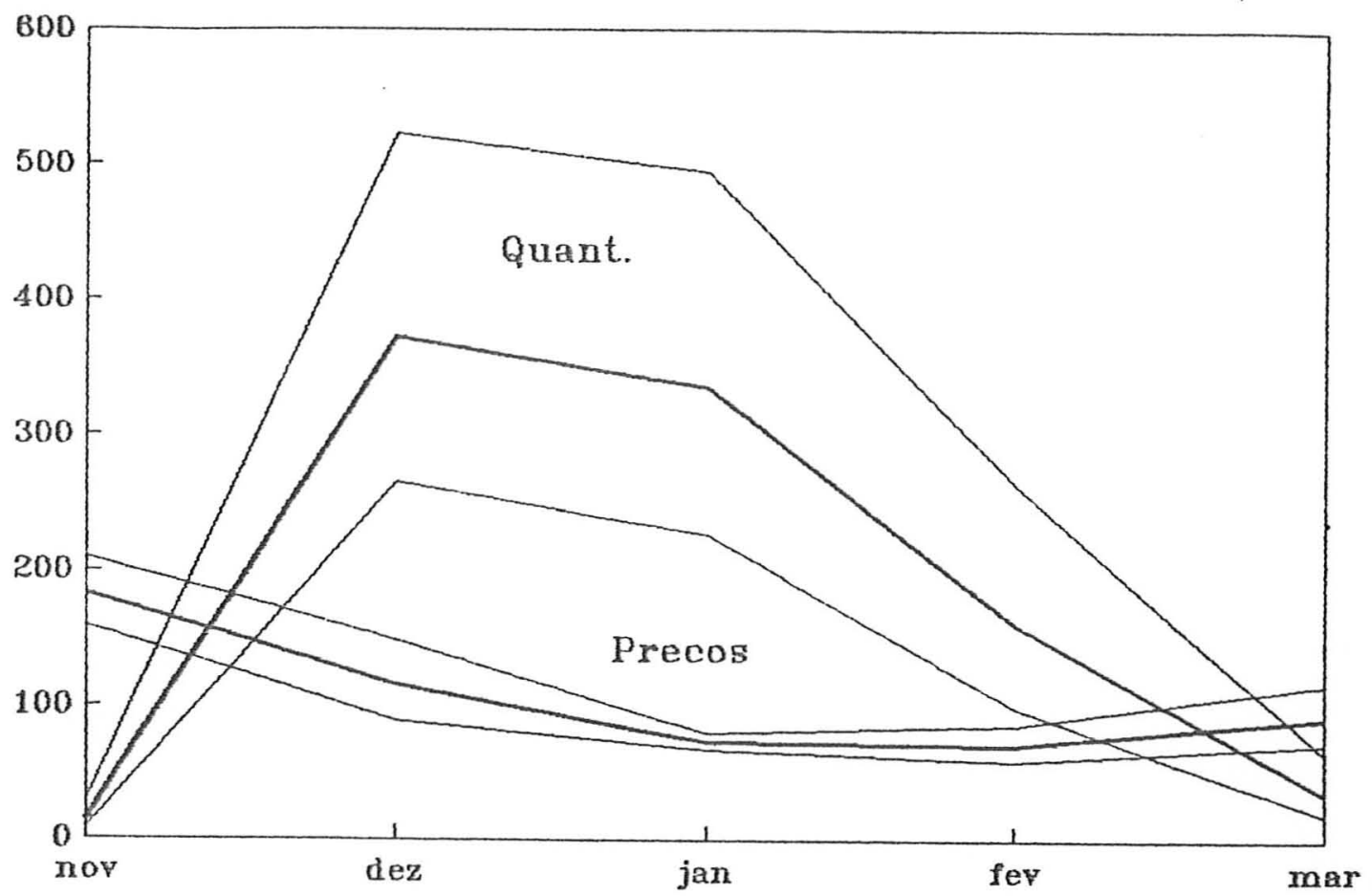

Figura 6.13- Variacão estacional de precas deflacionados $e$ quantidades de uva niágara $(c x t-6,00 \mathrm{~kg})$ no mercado atacadista de São Paulo. Periodo $1980-1988$.

Tabela 6.13- indices de variacão estacional de precos deflacionados e quantidades de uva niágara (ckt-6,00 kg) no mercado atacadista de 5 ão Paulo. Periodo 1980-1988.

MESES

Inferior

Médio

Superior Preco Quant. Preco Quant. Preco Quant.

\begin{tabular}{lrrrrrr}
\hline Novembro & 157,04 & 7,23 & 183,83 & 14,23 & 194,19 & 28,00 \\
Dezembro & 99,76 & 264,65 & 114,16 & 371,83 & 162,08 & 522,41 \\
Janeiro & 67,14 & 226,84 & 73,73 & 334,79 & 83,19 & 494,13 \\
Fevereiro & 55,13 & 98,61 & 70,63 & 161,29 & 87,94 & 263,80 \\
Marco & 69,58 & 19,00 & 91,52 & 34,99 & 107,59 & 64,46 \\
Teste F & - & - & 21,87 & 40,93 & - & - \\
\end{tabular}




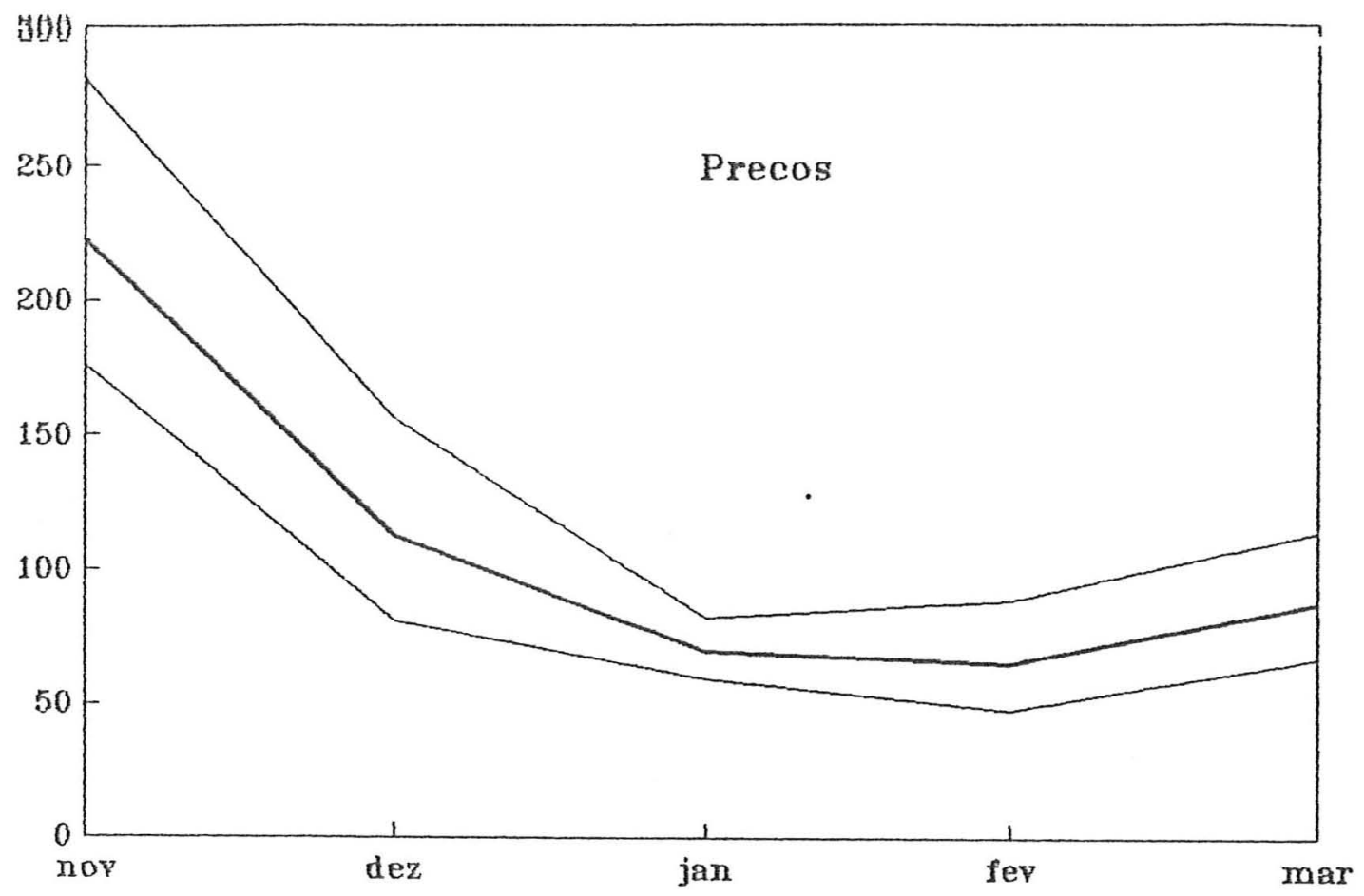

Figura 6.13.1-Variacăo estacional de precos deflacionados de uva niágara recebidos pelos produtores no Estado de São Paulo.

Tabela 6.13.1-indices de variacão estacional de precos deflacionados de uva niágara (cx $-8,00 \mathrm{~kg})$ recebidos pelos produtores no Estado de São Paulo. Periodo 1980-1988.

\begin{tabular}{lcrr}
\hline MESES & Inferior & Medio & Superior \\
\hline Novembro & 176,18 & 222,82 & 281,80 \\
Dezembro & 81,01 & 112,47 & 156,15 \\
Janeiro & 59,22 & 69,74 & 82,13 \\
Fevereiro & 47,77 & 65,16 & 89,87 \\
Marco & 67,20 & 87,79 & 114,60 \\
Teste F & - & 28,53 & - \\
\hline
\end{tabular}


Us resultados relativos à análise de variacão estacional de precos a nivel do atacado e do produtor. foram obtidos para as frutas que apresentaram uma série regular de precos aos dois niveis de mercado. Estas frutas são: figo, morango, uva comum e péssego.

A tangerina, apesar de apresentar uma série regular de precos aos dols niveis de mercado, não foi possivel comparar os padrões de variacão estacional, pois a nivel do atacado os precos são especificos por tipo de tangerina (cravo, murcote e poncan), enquanto que a nivel do produtor os precos são apresentados de forma mais geral. Para a macã nacional não foi possivel fazer análise comparativa pois o periodo de safra para o Estado de São Paulo (portanto os precos recebidos pelos produtores) é relativo a apenas 3 meses. No atacado o periodo de oferta se estende por 10 meses, dada a grande entrada de maçã sulina no mercado a partir de marco. Assim os padrões de variacão estacional observados a nivel do atacado e produtor devem ser bastante diferentes.

Os dados utilizados nos modelos de margens referem-se aos mesmos dados utilizados para o cálculo dos indices de variacão estacional para o periodo de 1980 a 1988.

Procurou-se analisar a politica de margens adotadas pelos intermediarios e verificar seus efeitos 
sobre os indices de variacão sazonal ao produtor, comparando com os indices obtidos no mercado atacadista.

Os resultados apresentados a seguir foram obtidos a partir dos dados disponiveis para 4 frutas (figo, morango, uva comum e pêssego).

Para o figo, o modelo estimado foi:

$$
M c=417,92+0,68 \mathrm{Pd}
$$

onde tanto o coeficiente Co quanto o coeficiente ci mostraram-se significativos ao nivel de $5 \%$. Isto caracteriza a utilizacão pelos atacadistas de margens relativas decrescentes e margens absolutas crescentes.

As margens, neste caso, não são rigidas e assim as variacões de preços tendem a refletir-se de forma relativamente proporcional do atacado para o produtor.

De. fato, os indices sazonais observados no atacado não diferem estatisticamente dos indices verificados ao nivel do produtor $\left(x_{0}^{2}=5,54\right.$ e $\left.x_{c}^{2}=11,07\right)$.

A amplitude de variacão de precos a nivel do produtor $(88,37)$ é maior que a amplitude verificada a nivel do atacado $(67,38)$. Isto ocorre porque o coeficiente Co, sendo diferente de zero, impede que as variacões de preco verificadas no atacado sejam refletidas de forma totalmente proporcional para o produtor.

Em modelos deste tipo, quanto menor for o coeficiente Co e maior o coeficiente C1, menor tende a ser 
a diferenca entre os indices obtidos para o atacado e o produtor. Isto seria próximo ao modelo de margens relativas constantes, isto é, o intermediário sempre acrescenta uma porcentagem fixa ao preco de compra, por isso os indices de variacão estacional seriam muito semelhantes no atacado e no produtor, pois as variacões de precos refletem-se de forma proporcional.

Para o morango, os resultados obtidos foram bastante semelhantes ao figo. A funcão ajustada para esta fruta foi:

$$
M c=387,81+0,14 \mathrm{Pd}
$$

Ao nivel de significância de $5 \%$, tanto o coeficiente Co quanto o coeficiente C1 mostraram-se estatisticamente significativos, caracterizando a utilizacão, pelos intermediários, de margens absolutas crescentes e margens relativas decrescentes.

Do mesmo modo que o figo, também não foram observadas diferencas significativas entre 05 indices de precos dos dois niveis de mercado $\left(x_{0}^{2}=1,98\right.$ e $\left.x_{c}{ }^{2}=12,59\right)$, ao nivel de $5 \%$ de significância.

Também neste caso, as variacões de preco no atacado refletiram-se de forma relativamente proporcional para o produtor.

Também neste caso a existência do coeficiente Co não foi suficiente para alterar significativamente os 
indices de preco ao nivel do produtor, mas aumentou a amplitude de variacão deste $(118,81\rangle$ em relacão a amplitude verificada nos indices do atacado $(104,63)$. (Ver tabela 6.7 e 6.7.1).

$$
\text { Para a uva comum foi ajustada a seguinte }
$$

funçัo.

$$
M c=870,39-0,41 \mathrm{Pd}
$$

Ao nivel de significância de $5 \%$, apenas Co mostrou significância estatistica, podendo-se concluir que os atacadistas adotam uma politica de margens absolutas constantes.

Segundo BRANDT (1979), os atacadistas procuram conduzir uma politica de margens absolutas constantes para tentar obter um retorno estável e razoável no curto prazo.

Entretanto, uma das consequências desta politica de margens fixas é fazer com que as variacones na demanda primária não sejam transmitidas de forma proporcional aos produtores, pois a rigidez de margem tende a exagerar as indicacões (de variacões na procura) aos produtores.

Assim como estas variacões são transmitidas de forma relativamente mais que proporcional é de se esperar que os indices estacionais de precos do atacado sejam diferentes daqueles obtidos dos precos ao produtor. 
De fato para a uva, os indices revelaram-se estatisticamente diferentes $\left(x_{0}{ }^{2}=9,25 \mathrm{e} x_{c}^{2}=7,81\right)$ para os dois niveis de mercado. Verificou-se também que os indices são mais intensos a nivel do produtor (ver tabelas 6.13 e 6.13.1) e a amplitude dos indices do produtor mostrou-se malor $(157,66)$ que a amplitude dos indices ao nivel do atacado $(112,20)$.

BRANDT (1979) destaca também que uma das condicões sine qua non para que os intermediários possam conduzir tal politica é a existência de poder monopolístico.

Para o pêssego, os resultados obtidos foram:

$$
M c=999,89-0,14 \mathrm{Pd}
$$

onde o coeficiente co mostrou-se significativo a $5 \%$ enquanto o coeficiente $C_{2}$ não o foi, ou seja o montante em cruzeiros adicionados pelos atacadistas não se modifica na faika de precos abrangida pelos dados disponiveis, indicando que os intermediários adotam uma politica de margens rigidas.

Utilizando estes dados para o cálculo dos indices estacionais ao atacado e ao produtor, verificou-se que estes diferem estatisticamente ao nivel de $5 \%$ de significância $\left(x_{0}{ }^{2}=9,41\right.$ e $\left.\chi_{c}{ }^{2}=7,81\right)$.

o resultado esperado é que os indices ao nivel do produtor fossem mais intensos que aqueles 
verificados a nivel do produtor, a ekemplo do caso anterior.

Entretanto, os resultados obtidos mostram que, ao contrário do esperado, os indices verificados ao nivel do produtor apresentam-se mais estáveis que a nivel do atacado, apesar de diferirem estatisticamente $i x_{0}{ }^{2}=$ 9,60 e $\left.\chi_{c}^{2}=7,81\right)$.

Uma das razões que pode explicar tal comportamento dos precos é a baika estacionalidade verificada nos precos do atacado $(F=6,30)$ ao contrário das demais frutas analisadas que apresentaram graus maiores de estacionalidade, o que pode afetar os resultados. Como as variações de preços são pouco intensas, seus reflexos ao nivel do produtor são pouco relevantes.

Assim pode-se notar que o efeito que a concentracão na comercializacão pode exercer sobre os indices sazonais dependera do tipo de margens adotadas pelos intermediários.

Normalmente por estes deterem grande volume comercializado, os intermediários conseguem manter uma margem fixa.

Neste caso, os indices verificados no atacado e ao nivel do produtor serão diferentes, pois os precos tendem a refletir-se de forma relativamente mais que proporcional aos produtores, que é o caso da uva comum e $5 e$ 
128.

além da margem fixa os intermediários acrescentarem uma porcentagem sobre o preco praticado, estes tendem a refletir-se de forma relativamente proporcional para o produtor, fazendo com que os indices estacionais nos dois niveis de mercado sejam semelhantes, como é o caso do figo e morango. 


\section{CONCLUSOES}

Este estudo procedeu a uma análise da variacăo de precos, em especial com respeito à sazonalidade de precos e quantidades de frutas estacionais no Estado de São Paulo, no periodo de 1980 a 1988.

Alguns fatores diretamente relacionados com a determinacão do padrão de variacão estacional de precos como o componente inflacionário, o componente ciclico e o componente tendencial foram analisados.

Alguns aspectos do mercado atacadista, onde são formados os preços analisados também foram estudados no que diz respeito ao aspecto de concentracăo na comercializacão e a relacão entre a concentração e a sazonalidade, através de modelos de politica de margens.

Com relaça aos fatores que afetam a estacionalidade observou-se que o componente inflacionário pode afetar a estimativa dos indices sazonais, principalmente quanda ef trata de produtas can aforta dégantinua efi presenca de taxas inflacionairias elevadas em relacão ao componente estacional. Nestes casos, um deflacionamento 
prévio é recomendado, caso contrário os indices podem se tornar sub ou superestimados.

Nos produtos estudados não se verificou a presenca de ciclos e o componente tendencial após o deflacionamento não interfere na utilização do modelo da média geométrica móvel que é a mais comumente usada.

Foram utilizados três indicadores de concentracão e um de desigualdade no volume comercializado. Todos os indicadores mostraram que a comercializacão de frutas é fortemente concentrada e desigual.

As principais razões que podem explicar o alto grau de concentracão na comercializacão são principalmente a concentracão na producão, acesso a infra-estruturas que aukiliam a comercializaçăo e o alto risco que implica o comércio de pereciveis.

As principais razões que explicaram a estacionalidade nos preços foram: competicão com outras frutas, temperatura, aumento da demanda $e$ quantidade comercializada.

0s resultados mostram que os meses ideais para o produtor colocar seus produtos no mercado são: janeiro para peras, marco para poncan, junho para caqui, julho para nêspera, agosto para mekerica, setembro para nectarina e manga, outubro para macă, novembro para uva comum e dezembro para ameixa, figo e pêssego. 
A concentrąão na comercializacão pode interferir na estimativa dos indices sazonais dependendo da politica de margens adotada pelos atacadistas.

Uma politica de margens rigidas faz com que os indices sazonais observados nos dois niveis de mercado sejam diferentes, ao passo que uma politica de margens flexiveis faz que os indices no atacado e ao produtor sejam semelhantes.

Dessa forma, politicas que visem aumentar a capacidade de armazenagem a frio com fins de estabilizar a sazonalidade de precos pode năo sentir efeito se for adotada uma politica de margens rigidas. 


\section{REFERÉNCIAS BIBLIOGRXFICAS}

ALMEIDA, L.A.S.B. Estudos econômicos: Alimentos processados. Boletim do Instituto de Tecnologia de Alimentos. Campinas, (25):3-39, 1985 .

ALMEIDA, F.R.F. A estrutura da comercialização atacadista de alimentos básicos. In: SEMINÁRIO NACIONAL DE ABASTECIMENTO ALIMENTAR EM GRANDES CIDADES: A EXPERIENNCIA DE São PAULo, São Paula, 1984. Anais .... São Paulo, Secretaria de Agricultura e Abastecimento, 1984.

AssumpCão, A.G.; GaLINA, L.A.; MAKaWA, M.; CONSONI, R. Estudo da formacão de precos de hortifrutigranjeiros e cereais em Maringá. Revista de Economia e Sociologia Rural, $28(1): 89-104, j$ an-mar/1990.

BARROS, G.S.C. Formąão de prefos agricolas e seus reflexos sobre o abastecimento. Revista de Economia e Sociologia Rural, $27(1): 1-4, j$ an-mar/1989. 
BRANDT, S.A. O mercado agricola brasileiro. São Paulo. Nobel, 1979. 145p.

CARVALHO, F.C.; NETTO, D.D.; NOGUEIRA Jr., S. Concentracão da capacidade industrial de soja em grão no Brasil. São Paulo, Secretaria de Agricultura e Abastecimento. IEA. 1984, 16p. (Relatório de Pesquisa 6/84).

CARUALHO, F.C.; SOARES, M.F.U.; NETTO, D.D. Margens de comercializațão de pescado em São Paulo - 1975/77. São Paulo, Secretaria de Agricultura e Abastecimento/IEA, 1980 (Relatório de Pesquisa 10/80).

CARUALHO, F.C. \& NABHAN, M. Paises europeus como mercados para produtos hortigranjeiros selecionados. São Paulo, Secretaria de Agricultura e Abastecimento. 1984. 27p. (Relatório de Pesquisa 11/84).

CAVES, R. Estrutura industrial americana. Rio de Janeiro, Zahar, 1967. 180p.

COMPANHIA DE DESENUOLUIMENTO DO UALE DO RIO SÃO FRANCISCO. Frutas brasileiras: exportąão. Brasilia, 1989. 353p. 
COMPANHIA DE ENTREPOSTOS E ARMAZÉNS GERAIS DO ESTADO DE SÃO PAULo. Boletins Mensais e Boletim Anual. São Paulo, Secretaria de Agricultura e Abastecimento, 1980-1988.

DICLER, M.P.N. A comercializaço de frutas no municipio de Botucatu - SP. 1989. 182P. (Tese de Mestrado - Faculdade de Ciências Agronômicas - UNESP).

DOMINGUES, A.F. A estrutura da comercializacão atacadista de hortigranjeiros e a ação do Estado no setor. In: SEMINARIO NACIONAL DE ABASTECIMENTO ALIMENTAR EM GRANDES CIDADES - A EXPERIÉNCIA DE SÃo PAULO, São PaUlo, 1984. Anais .... São Paulo, Secretaria da Agricultura e Abastecimento, 1984 .

HOEL, P.G. Estatistica elementar. 4.ed. New York, John Wiley \& Sons, 1982, 312p.

X HOFFMANN, R. Variacão estacional de produtos agropecuários no Estado de São Paulo. Piracicaba, 1969.184p. (Tese Doutorado - Escola Superior de Agricultura "Luiz de Queiroz", Universidade de São Paulo).

HOFFMANN, R. Estatistica para economistas. São Paulo, Pioneira, 1980. 379p. 
HOFFMANN, R. Administracão da empresa agricola. São Paulo, Pioneira, 1976. $346 \mathrm{p}$.

JANECKE, T. \& ALUENSLEBEN, R. won. Some special aspects of seasonal supply and price variation of fruit and vegetable markets. Acta horticulturae, (223):291-4, 1988 .

KOHLS, R.L. Marketins of agricultural products. New York. McMillan, 1985. 624p.

LANGE, 0. Introducão à econometria. 2.ed. Rio de Janeiro, Fundo de Cultura, 1967. 374p.

LEMOS, J.J.S.; BRANDT, S.A.; TOLLINI, H.; PANIAGO, E. Análise espectral de ciclos de comércio agricola no Brasil. Revista de Economia e Sociologia Rural. 27(1):5-19, jan$\operatorname{mar} / 1989$

*MARQuES, P.V. \& AGUIAR, D.R.D. Comercializacão de produtos agricolas. Série didatica, $n \cong 54.1989$.

MORETTIN, P.A. \& TOLOI, C.M.C. Previsão de séries temporais. São Paulo, Atual, 1985. 439p. 
NOGUEIRA, E.A. et alii. Frutas de clima temperado; estacionalidade de precos e de quantidade no mercado atacadista de São Paulo. Informacões econômicas, (9):25$44,1984$.

NOGUEIRA, E.A. et alii. Frutas de clima tropical: estacionalidade de precos e de quantidade no mercado atacadista de São Paulo. Informacões Econômicas, (5):3560,1985 .

DJIMA, M. et alii. Fruticultura de clima temperado no Estado de São Paulo. Diagnóstico da situação econômica e cultural e atividades de pesquisa no IAC. Boletim Técnico do Irstituto Agrorômico de Campinas. Campinas, IAC. $89: 1-303,1984$.

PENTEADO, S.R. Fruticultura de clima temperado em São Paulo. Campinas, Fundação Cargil, 1986. 257p.

PEREIRA, I.F. et alii. Variacăo estacional de precos agricolas no Estado de São Paulo. Agricultura em São Paulo. São Paulo, (10):3-67, 1963 
PERosA, J.M.Y. O tomate no Estado de Săo Paulo, producão, comercializacão e preços. São Paulo, 1985, $174 p$. (Dissertacão - Mestrado - Escola de Administracão de Empresas de São Paulo, FGU).

RIBEIRO, A.C. Rentabilidade na estocagem de produtos agricolas. Vicosa, 1977. 73p. (Tese de Mestrado-Universidade Federal de Vicosal.

Săo PAULO, Secretaria de Agricultura e Abastecimento/FAO. Abastecimento no Estado de São Paulo, 1982. São Paulo, 1982. 120p.

SÃo PAULO, Secretaria de Agricultura e Abastecimento. Informacões Econômicas. Diversas publicą̧ões.

SATO, G.S. Variacão de preços da cebola. Piracicaba, 1988. 122p. (Tese - Mestrado - Escola Superior de Agricultura "Luiz de Queiroz", Universidade de São Paulo).

SHEPHERD, G.S. Marketing farm products. Ames, Yowa University, 1946. 427p.

SPIEGEL, M.R. Estatistica. São Paulo. MeGraw Hill, 1970. $320 p$. 
THOMSEN, F.L. \& FOOTE, R.L. Agricultural price. Washington, MacGraw Hill, 1952. 303p.

WERNER, R.A. \& BRAUN, R.L. Horticultura: questões de abastecimento. Florianópolis, ACARESC. 1983. $73 p$.

YAMANE, T. Statistics; an introductory analysis. 3.ed. New York, Harper \& Row, 1975. 1130F. 


$$
A P \hat{E N D I C E A}
$$


Neste apêndice são examinados três tipos de comportamentos de precos face às taxas de inflacão e sua influência sobre a estimativa dos indices sazonais. Estes tipos de comportamentos são:

(1) taka de inflação constante

(2) taxas de inflacão pouco significativas

(3) taxas de inflação irregulares

(4) taxas de inflação elevadas e irregulares

Estes comportamentos são analisados segundo os métodos das médias geométrica e aritmética.

Na Tabela A.1 são apresentados dados hipotéticos de precos e indices de inflação e o comportamento dos indices estacionais. 
Tabela A.1-indices estacionais estimados pela médià aritmé tica a partir de prexas nominais e deflacionados cujo indice de inflacão cresce a um valor constante.

\begin{tabular}{|c|c|c|c|c|c|c|c|c|c|c|}
\hline Mês & 1 & 2 & 3 & 4 & 5 & 6 & 7 & 8 & 9 & 10 \\
\hline$P$ Nominal & 100 & 110 & 120 & 130 & 140 & 150 & 160 & 170 & 180 & 190 \\
\hline $\begin{array}{l}\text { Média } \\
\text { Aritmet ica }\end{array}$ & - & - & 120 & 130 & 140 & 150 & 160 & 170 & - & - \\
\hline $\begin{array}{l}\text { Indice Es- } \\
\text { tacional }\end{array}$ & - & - & $\theta$ & $\theta$ & $\theta$ & 0 & $\theta$ & 0 & - & - \\
\hline P. Real & 100 & 100 & 100 & 100 & 100 & 100 & 100 & 100 & 100 & 100 \\
\hline $\begin{array}{l}\text { Média } \\
\text { Aritmét ica }\end{array}$ & - & - & 100 & 100 & 100 & 100 & 100 & 100 & - & - \\
\hline $\begin{array}{l}\text { Indice Es- } \\
\text { tacional }\end{array}$ & - & - & $\theta$ & $\theta$ & 0 & 0 & 0 & 0 & - & - \\
\hline $\begin{array}{l}\text { Indice de* } \\
\text { Inflacão }\end{array}$ & 100 & 110 & 120 & 130 & 140 & 150 & 160 & 170 & 180 & 190 \\
\hline
\end{tabular}

"Dados Hipotéticos.

0 componente inflacionário $A_{q}$ é igual a 10 para todo $t$, o acréscimo do preco devido à inflacão $A_{t}$ é $O$ mesmo em todos os meses, sendo naturalmente eliminado pela média móvel, como mostra a tabela. A média móvel acompanha "pari passu" a evolucão de precos e como a série não apresenta um comportamento estacional, os indices calculados são todos iguais a zero.

Nestes casos usar precos deflacionados ou nominais é indiferente, pois ao subtrair a média móvel do preco eliminä-se o componente inflacionário. 
0 uso de deflacionamento também se tornará desnecessário se o componente inflacão for pouco significativo em relacão ao componente estacional

Por isso, trabalhos anteriores atestam a indiferenca quanto ao uso dos precos reais ou deflacionados.

Supondo-se que haja um aumento de precos devido à inflacão de uma unidade como mostra a Tabela A.2, a seguir, os desvios dos indices estacionais mínimos em relação à média aritmética

Tabela A.2- indices estacionais estimados pela média àritmé tica a partir de precos nominais deflacionados cuja série de precos apresenta o componente inflacionário pouco significativo.

\begin{tabular}{|c|c|c|c|c|c|c|c|c|c|c|c|}
\hline Mês & 1 & 2 & 3 & 4 & \multicolumn{2}{|c|}{5} & 6 & 7 & 8 & 9 & 10 \\
\hline $\begin{array}{l}\text { Preco* } \\
\text { Corrente }\end{array}$ & 100 & 100 & 100 & 100 & \multicolumn{2}{|c|}{100} & 101 & 101 & 101 & 101 & 101 \\
\hline $\begin{array}{l}\text { Média } \\
\text { Aritmética }\end{array}$ & - & - & 100 & 100,2 & \multicolumn{2}{|c|}{100,4} & 100,6 & \multicolumn{2}{|c|}{100,8} & - & - \\
\hline $\begin{array}{l}\text { Indice es- } \\
\text { tacional }\end{array}$ & - & - & $\theta$ & $-0,2$ & \multicolumn{2}{|c|}{$-0,4$} & 0,4 & \multicolumn{2}{|c|}{0,20} & - & - \\
\hline P.Real & \multicolumn{2}{|c|}{100} & 100 & 100 & 100 & 100 & 100 & 100 & 100 & 100 & 100 \\
\hline $\begin{array}{l}\text { Média } \\
\text { Aritmética }\end{array}$ & \multicolumn{2}{|l|}{3} & - & 100 & 100 & 100 & 100 & 100 & 100 & - & - \\
\hline $\begin{array}{l}\text { indice es- } \\
\text { tacional }\end{array}$ & \multicolumn{2}{|l|}{-} & - & $\theta$ & 0 & $\theta$ & 0 & $\theta$ & 0 & - & - \\
\hline $\begin{array}{l}\text { Indice de } \\
\text { Infląão }\end{array}$ & \multicolumn{2}{|r|}{100} & 100 & 100 & 100 & 100 & 101 & 101 & 101 & 101 & 101 \\
\hline
\end{tabular}

*Dádos Hipotéticos. 
Os vieses observados nos indices são dados pelo próprio valor do indice estacional $(-0,2,-0,4,0,4$ e Q,2), já que a série não apresenta comportamento estacional. Entretanto, em uma economia inflacionária como a brasileira, principalmente a partir dos anos 86 onde as indices de inflacão foram alterados por vezes de forma drástica as consideracões acima não se aplicam

A irregularidade observada nos indices impede que o componente inflacionário seja elimirado pelo método da média móvel.

Nestes casos, se não houver um prévio deflacionamento de precos, a média móvel se torna não representativa dos movimentos.

Este problema foi ressaltado por THOMSEN e FOOTE (1952), quando afirmam que "quando aparecem flutuacốes marcantes na série de dados, à média móvel será não representativa. Os movimentos episódicos marcantes de alta ou de queda subsequente torna a média móvel totalmente não representativa das condicões imediatamente antes, durante e depois do movimento".

Este fenômeno não se dá àpenas quando da ocorrência de alteracôes bruscas nos indices de inflacão, mas podem ocorrer como consequência de fenômenos climáticos, uma seca severa, por exemplo.

Pode-se dizer, portanto, que o deflacionamen- 
to é necessário para periodos onde as taxas inflacionarias são elevadas e irregulares.

$$
\text { Este problema pode ser ilustrado pelà Tabela }
$$

a seguir

Tabela A.3- indices estacionais estimados pela média aritmé tica móvel a partir de preqos nominais e deflacionados de uma série que apresenta variacão brusca no componente inflacionário

\begin{tabular}{lcccccccccc}
\hline Mês & 1 & 2 & 3 & 4 & 5 & 6 & 7 & 8 & 9 & 10 \\
\hline P.Nominal & 100 & 100 & 100 & 100 & 100 & 200 & 200 & 200 & 200 & 200
\end{tabular}

Média

\begin{tabular}{lcccccccccc} 
Aritmética & - & - & 100 & 120 & 140 & 160 & 180 & 200 & - & - \\
$\begin{array}{l}\text { Indice Es- } \\
\text { tacional }\end{array}$ & - & - & 0 & -20 & -40 & 40 & 20 & 0 & - & - \\
\hline Preco Real & 100 & 100 & 100 & 100 & 100 & 100 & 100 & 100 & 100 & 100
\end{tabular}

Média

Aritmética - $\quad-\quad 100 \quad 100 \quad 100 \quad 100 \quad 100100 \quad-$
Indice Estacional indice de* Inflacão $100 \quad 100 \quad 100 \quad 100 \quad 100 \quad 200 \quad 200 \quad 200 \quad 200 \quad 200$

* Dados Hipotéticos.

Na passagem do més 5 para o més b, os pregos sofreram uma elevacão de $100 \%$ e a tabela mostra qual efeito sobre as estimativas do componente estacional. Antes da elevacão brusca de precos, a média móvel está superestimada em relacão aos precos e, após o movimento, os 
indices estão superestimados em relą̧ão à série de precos.

Tabela A.4- Indices estacionais estimados pela média aritmé tica móvel a partir de precos nominais $e$ deflacionados de uma série que apresenta componente inflacionário elevado e irregular.

\begin{tabular}{lrrrrrrrrrrrr}
\hline Mês & 1 & 2 & 3 & 4 & 5 & 6 & 7 & 8 & 9 & 10 \\
\hline P.Nominal * 100 & 126 & 158 & 205 & 226 & 237 & 247 & 290 & 389 & 387
\end{tabular}

Média

Aritmética - $\quad$ - $\quad \begin{array}{lllllllll} & 165 & 190,4 & 214 & 241 & 277,4 & 309 & \text { - }\end{array}$

$\begin{array}{llllllllll}\text { indice Es- } & - & - & -7 & 14,6 & 12 & -4 & -30 & -19 & -\end{array}$

\begin{tabular}{lllllllllll}
\hline Preco Real 100 & 100 & 100 & 100 & 100 & 100 & 100 & 100 & 100 & 100
\end{tabular}

Média

Aritmética - $\quad-\quad \begin{array}{lllllllll} & 100 & 100 & 100 & 100 & 100 & 100 & -\end{array}$

Indice Es- $\quad-\quad-\quad 0 \quad 0 \quad 0000000$ -

tacional

indice de

Infląão

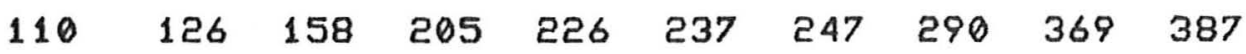

*Dados Hipotéticos.

Nesta tabela pode-se observar que quando as taxas de inflacão são elevadas e irregulares, os indices estacionais mostram-se ora super ora subestimados. Se a taxa de inflação aumenta, o indice será superestimado, se a taxa de inflacão cai, o indice se torna subestimado. 
A elevacão de preços, que é uma questão puramente inflacionária, afetou de forma efetiva as estimativas dos componentes estacionais. Antes do movimento 05 indices estacionais estarão subestimados em 20 e 40 unidades $e$ após o ponto critico, os indices estacionais estarão superestimados em 40 e 20 unidades.

Estas consideracõos são válidas para o método da média geometrica, supondo um modelo tal que:

$$
x_{t}=A \cdot B^{t} \cdot \varepsilon_{i} \cdot I_{t} \cdot u_{t}
$$

onde $t=1,2, \ldots n$, onde $n \dot{e}$ o numero total de meses. $X_{l}=$ preço no mês $t, A$ e $B$ ão parâmetros da funcão que determina a tendência, $\epsilon_{\mathfrak{l}}=$ componente estacional, $I_{\downarrow}=$ componente inflacionário (takas inflacionárias mensais) e $u_{l}=$ componente aleatório.

$$
E\left[\frac{E_{l} \cdot I_{l}}{\left(I_{l-\sigma} \cdots I_{l} \cdots I_{l+6}\right)^{1 / 12}}\right]=\epsilon_{l}
$$

A eq. (A.2) deve ocorrer nos casos onde $I_{\downarrow}$ é constante, isto é, não existe inflacão e $I_{t}$ varia a uma taxa constante em relacão ao mês anterior.

O deflacionamento é recomendado nos casos em que há alteracões muito bruscas de precos devido à inflacão como mostra a Tabela a seguir. 
Tabela A.5- indices estacionais estimados através do método da média geometrica a partir de precos reais e nominais de uma série que apresenta alteracão brusca do componente inflacionário.

\begin{tabular}{|c|c|c|c|c|c|c|c|c|c|c|}
\hline Mês & 1 & 2 & 3 & 4 & 5 & 6 & 7 & 8 & 9 & 10 \\
\hline $\begin{array}{l}\text { Preco* } \\
\text { Nominal }\end{array}$ & 100 & 100 & 100 & 100 & 100 & 200 & 200 & 200 & 200 & 200 \\
\hline $\begin{array}{l}\text { Média } \\
\text { Geométrica }\end{array}$ & - & - & 100 & 114,87 & 131,92 & 151,57 & 174,11 & 200 & - & - \\
\hline $\begin{array}{l}\text { Indice es- } \\
\text { tacional }\end{array}$ & - & - & 100 & 87,06 & 75,79 & 131,95 & 114,87 & 100 & - & - \\
\hline Diferenca & - & - & $\theta$. & 12,94 & 24,21 & $-31,95$ & $-14,87$ & 0 & - & - \\
\hline $\begin{array}{l}\text { Preco } \\
\text { Real }\end{array}$ & 100 & 100 & 100 & 100 & 100 & 100 & 100 & 100 & 100 & 100 \\
\hline $\begin{array}{l}\text { Média } \\
\text { Geométrica }\end{array}$ & - & - & 100 & 100 & 100 & 100 & 100 & 100 & - & - \\
\hline $\begin{array}{l}\text { indice } \\
\text { estacional }\end{array}$ & - & - & 100 & 100 & 100 & 100 & 100 & 100 & - & - \\
\hline $\begin{array}{l}\text { Indice de } \\
\text { Inflacão }\end{array}$ & 100 & 100 & 100 & 100 & 100 & 200 & 200 & 200 & 200 & 200 \\
\hline
\end{tabular}

Dados Hipotéticos

Nota-se que imediatamente antes da alteracão de preços, os indices estacionais estão subestimados, e superestimados após o fenômeno, quando comparados aos indices calculados para precos reais.

No caso dos indices permanecerem constantes numa taxa de $10 \%$, por exemp 10 , verifica-se que os indices estacionais calculados para precos reais e nominais são os mesmos, como mostra a Tabela a seguir. 
Tabela A.6 - Indices estacionais obtidos pelo eetodo da redia georetrica a partir de precos reais e noainais obtidos de ua serie que apresenta o componente inflacionario constante.

\begin{tabular}{|c|c|c|c|c|c|c|c|c|c|c|}
\hline KES & 1 & 2 & 3 & 4 & 5 & 6 & 7 & 8 & 9 & 10 \\
\hline $\begin{array}{l}\text { Preco } \\
\text { Noainal }\end{array}$ & 100 & 110 & 121 & 133,10 & 144,41 & 158,85 & 174,74 & 192,21 & 211,43 & 232,57 \\
\hline $\begin{array}{l}\text { Hedia } \\
\text { Geoestrica }\end{array}$ & - & - & 121 & 133,10 & $\{44,41$ & 158,85 & 174,74 & $192, \tilde{c} 1$ & 211,43 & 232,57 \\
\hline $\begin{array}{l}\text { Indice } \\
\text { estacional }\end{array}$ & - & - & 100 & 100 & 100 & 100 & 100 & 100 & 108 & 100 \\
\hline $\begin{array}{l}\text { Preco } \\
\text { Real }\end{array}$ & 100 & 100 & 100 & 100 & 100 & 100 & 100 & 100 & 100 & 105 \\
\hline $\begin{array}{l}\text { Media } \\
\text { Geometrica }\end{array}$ & - & - & 100 & 100 & 100 & 100 & 100 & 100 & - & - \\
\hline $\begin{array}{l}\text { Indice } \\
\text { estacional }\end{array}$ & - & - & 109 & 100 & 100 & 100 & 100 & 100 & - & - \\
\hline $\begin{array}{l}\text { Indice de } \\
\text { Inflacao }\end{array}$ & 100 & 110 & 121 & 133,10 & 146,41 & 161,05 & 177,15 & 194,87 & 214,35 & 235,79 \\
\hline
\end{tabular}

" Dados Hipoteticos 
Dutro caso onde o deflacionamento é dispensável, é quando os indices inflacionários são pouco significativos, em relacão aos precos (Tabela A.b).

Tabela A.7- indices estacionais estimados pelo método da média geometrica a partir de precos reais e deflacionados de uma série que apresenta o componente inflacionário pouco significativo.

\begin{tabular}{|c|c|c|c|c|c|c|c|c|c|c|}
\hline Mês & 1 & 2 & 3 & 4 & 5 & 6 & 7 & 8 & 9 & 10 \\
\hline $\begin{array}{l}\text { Precon } \\
\text { Nominal }\end{array}$ & 100 & 100 & 100 & 100 & 100 & 105 & 105 & 105 & 105 & 105 \\
\hline $\begin{array}{l}\text { Média } \\
\text { Geométric }\end{array}$ & $a^{-}$ & - & 100 & 100,98 & 101,97 & 102,97 & 103,98 & 105 & - & - \\
\hline $\begin{array}{l}\text { indice Es } \\
\text { tacional }\end{array}$ & - & - & 100 & 99,03 & 98,07 & 101,97 & 100,98 & 100 & - & - \\
\hline
\end{tabular}

"Dados Hipotéticos.

Este problema de super e subestimafơ dos componentes estacionais tende a ocorrer com maior intensidade quando se trata de produtos com oferta descontinua. 
Tabela A.8 - Indices estacionais estirados pelo etodo da edia geometrica a partir de precos reais e deflacionados de uga serie que apresenta 0 conponente intlacionario elevado e irregular.

\begin{tabular}{|c|c|c|c|c|c|c|c|c|c|c|}
\hline Hes & 1 & 2 & 3 & 4 & 5 & 6 & 7 & 8 & 9 & 10 \\
\hline $\begin{array}{l}\text { Preco } \\
\text { Noninal }\end{array}$ & 110 & 126 & 158 & 205 & 226 & 237 & 247 & 290 & 389 & 387 \\
\hline $\begin{array}{l}\text { Kedia } \\
\text { Geowetrica }\end{array}$ & - & - & 158,9 & 185,3 & 212,0 & 239 & 272,13 & 303,04 & - & - \\
\hline $\begin{array}{l}\text { Indice } \\
\text { estacional }\end{array}$ & - & - & 99,4 & 110,63 & 106,6 & 99,2 & 90,7 & 90,7 & - & - \\
\hline $\begin{array}{l}\text { Preco } \\
\text { Real }\end{array}$ & 100 & 100 & 100 & 100 & 100 & 100 & 100 & 100 & 100 & 100 \\
\hline $\begin{array}{l}\text { Kedia } \\
\text { Geoestrica }\end{array}$ & - & - & 190 & 100 & 100 & 104 & 100 & 100 & - & - \\
\hline $\begin{array}{l}\text { Indice } \\
\text { estacional }\end{array}$ & - & - & 100 & 100 & 100 & 100 & 100 & 100 & - & - \\
\hline $\begin{array}{l}\text { Indice de } \\
\text { Inflacao }\end{array}$ & 110 & 126 & 158 & 205 & 226 & 237 & 247 & 290 & 389 & 387 \\
\hline
\end{tabular}

* Dados hipoteticos

Neste caso observa-se que taxas de inflą) elevadas e irregulares tendem a provocar tendenciosidade nos indices. 